C55.13:NMFS CIRC 424

\title{
424
}

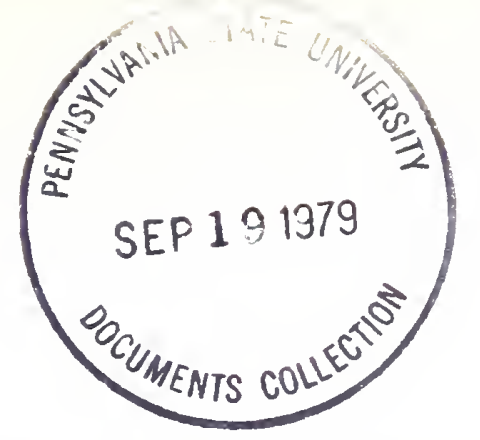

NOAA Technical Report NMFS Circular 424

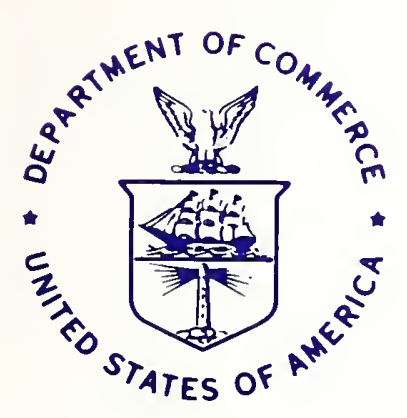

\section{Guide to the Leptocephali (Elopiformes, Anguilliformes, and Notacanthiformes)}

David G. Smith

July 1979 


\section{NOAA TECHNICAL REPORTS}

\section{National Marine Fisheries Service, Circulars}

The major responsibilities of the National Marine Fisheries Service (NMFS) are to monitor and assess the abundance and geographic distribution of fishery resources, to understand and predict fluctuations in the quantity and distribution of these resources, and to establish levels for optimum use of the resources. NMFS is also charged with the development and implementation of policies for managing national fishing grounds, development and enforcement of domestic fisheries regulations, surveillance of foreign fishing off United States coastal waters, and the development and enforcement of international fishery agreements and policies. NMFS also assists the fishing industry through marketing service and economic analysis programs, and mortgage insurance and vessel construction subsidies. It collects, analyzes, and publishes statistics on various phases of the industry.

The NOAA Technical Report NMFS Circular series continues a series that has been in existence since 1941. The Circulars are technical publications of general interest intended to aid conservation and management. Publications that review in considerable detail and at a high technical level certain broad areas of research appear in this series. Technical papers originating in economics studies and from management investigations appear in the Circular series.

NOAA Technical Report NMFS Circulars are available free in limited numbers to governmental agencies, both Federal and State. They are also available in exchange for other scientific and technical publications in the marine sciences. Individual copies may be obtained (unless otherwise noted) from D825, Technical Information Division, Environmental Science Information Center, NOAA, Washington, D.C. 20235. Recent Circulars are:

365. Processing EASTROPAC STD data and the construction of vertical temperaturc and salinity sections by computer. By Forrest R. Miller and Kenneth A. Bliss. February 1972, iv +17 p., 8 figs., 3 app. figs. For sale by the Superintendent of Documents, U.S. Government Printing Office, Washington, D.C. 20402.

366. Kev to field identification of anadromous juvenile salmonids in the Pacific Northwest. By Robert J. MacConnell and George R. Snyder. January 1972, iv +6 p., 4 figs. For sale by the Superintendent of Documents, U.S. Government Printing Office, Washington, D.C. 20402.

367. Engineering economic model for fish protein concentration processes. By K. K. Almenas, L. C. Durilla, R. C. Ernst, J. W. Gentry, M. B. Hale, and J. M. Marchello. October 1972, iii +175 p., 6 figs., 6 tables. For sale by the Superintendent of Documents, U.S. Government Printing Office, Washington, D.C. 20402.

368. Cooperative Gulf of Mexico estuarine inventory and study, Florida: Phase I, area description. By J. Kneeland McNulty, William N Lindall, Jr., and James E. Sykes. November 1972, vii + 126 p., 46 figs., 62 tables. For sale by the Superintendent of Documents, U.S. Government Printing Office, Washington, D.C. 20402.

369. Field guide to the anglefishes (Pomacanthidae) in the western Atlantic. By Henry A. Feddern. November 1972 , iii +10 p., 17 figs. For sale by the Superintendent of Documents, U.S. Government Printing Office, Washington, D.C. 20402.

370. Collecting and processing data on fish eggs and larvae in the California Current region. By David Kramer, Mary J. Kalin, Elizabeth G. Stevens, James R. Thrailkill, and James R. Zweifel. November 1972, iv +38 p., 38 figs., 2 tables. For sale by the Superintendent of Documents, U.S. Government Printing Office, Washington, D.C. 20402.

371. Ocean fishery management: Discussion and research. By Adam A. Sokoloski (editor). (17 papers, 24 authors.) April 1973, vi + 173 p., 38 figs., 32 tables, 7 app. tables.

372. Fishery publications, calendar vear 1971: Lists and indexes. By Thomas A. Manar. October 1972 , iv +24 p., 1 feg. For sale by the Superintendent of Documents, U.F. Government Printing Office, Washington, D.C. 20402.

374. Marine flora and fauna of the northeastern United States. Annelida: Oligochaeta. By David G. Cook and Ralph O. Brinkhurst. May 1973 , iii +23 p., 82 figs. For sale by the Superintendent of Documents, U.S. Government Printing Office, Washington, D.C. 20402

375. New Polychaeta from Beaufort, with a key to all species recorded from North Carolina. By John H. Day. July 1973, xiii + 140 p., 18 figs., 1 table. For sale by the Superintendent of Documents, U.S. Government Printing Office, Washington, D.C. 20402.

376. Bottom-water temperatures on the continental shelf, Nova Scotia to New Jersey. Bv John B. Colton. Jr. and Ruth R. Stoddard. June 1973, iii +55 p., 15 figs., 12 app. tables. For sale by the Superintendent of Documents, U.S. Government Printing Office, Washington, D.C. 20402.
377. Fishery publications, calendar year 1970: Lists and indexes. By Mary Ellen Engett and Lee C. Thorson. December 1972, iv + 34 p., 1 fig. For sale hy the Superintendent of Documents, U.S. Government Printing Office, Washington. D.C. 20402.

378. Marine flora and fauna of the northeastern United States. Protozoa: Ciliophora. By Arthur C. Borror. September 1973, iii + 62 p. 5 figs. For sale by the Superintendent of Documents, U.S. Government Printing Office, Washington, D.C. 20402.

379. Fishery publications, calendar year 1969: Lists and indexes. By Lee C. Thorson and Mary Ellen Engett. April 1973, iv + 31 p., 1 fig. For sale by the Superintendent of Documents, U.S. Government Printing Office, Washington, D.C. 20402

380. Fishery publications, calendar year 1968: Lists and indexes. By Marv Ellen Engett and Lee C. Thorson. May 1973, iv + 24 p. 1 fig. For sale by the Superintendent of Documents, U.S. Government Printing Office, Washington. D.C. 20402

381. Fishery publications, calendar year 1967: Lists and indexes. By Lee C. Thorson and Mary Ellen Engett. July 1973, iv +22 p., 1 fig. For sale by the Superintendent of Documents, U.S. Government Printing Office, Washington. D.C. 20402

382. Fishery publications, calendar year 1966: Lists and indexes. By Mary Ellen Engett and Lee C. Thorson. July 1973, iv +19 p., 1 fig. For sale by the Superintendent of Documents, U.S. Government Printing Office, Washington, D.C. 20402

383. Fishery publications, calendar year 1965: Lists and indexes. By Lee C. Thorson and Mary Ellen Engett. July 1973, iv +12 p., 1 fig. For sale by the Superintendent of Documents, U.S. Government Printing Office, Washington, D.C. 20402.

384. Marine flora and fauna of the northeastern United States. Higher plants of the marine fringe. By Edwin T. Moul. September 1973, iii +60 p., 109 figs. For sale by the Superintendent of Documents, U.S. Government Printing Office, Washington, D.C. 20402.

385. Fishery publications, calend ar year 1972: Lists and indexes. By Lee C. Thorson and Mary Ellen Engett. November 1973, iv + 23 p., 1 fig. For sale by the Superintendent of Documents, U.S. Government Printing Office, Washington, D.C. 20402.

386. Marine flora and fauna of the northeastern United States. Pycnogonida. Bv Lawrence R. McCloskey. September 1973, iii + 12 p., 1 fig. For sale by the Superintendent of Documents, U.S. Government Printing Office, Washington, D.C. 20402

387. Marine flora and fauna of the northeastern United States. Crustacea: Stomatopoda. By Ravmond B. Manning. February 1974, iii + 6 p., 10 figs. For sale by the Superintendent of Document8, U.S. Government Printing Office, Washington, D.C. 20402 
NOAA Technical Report NMFS Circular 424

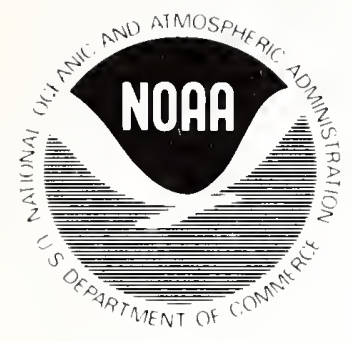
Guide to the Leptocephali
(Elopiformes, Anguilliformes, and Notacanthiformes)

David G. Smith

July 1979

U.S. DEPARTMENT OF COMMERCE

Juanita M. Kreps, Secretary

National Oceanic and Atmospheric Administration

Richard A. Frank, Administrator

Nationai Marine Fisheries Service

Terry L. Leitzell, Assistant Administrator for Fisheries 
The National Marine Fisheries Service (NMFS) does not approve, recommend or endorse any proprietary product or proprietary material mentioned in this publication. No reference shall be made to NMFS, or to this publication furnished by NMFS, in any advertising or sales promotion which would indicate or imply that NMFS approves, recommends or endorses any proprietary product or proprietary material mentioned herein, or which has as its purpose an intent to cause directly or indirectly the advertised product to be used or purchased because of this NMFS publication. 


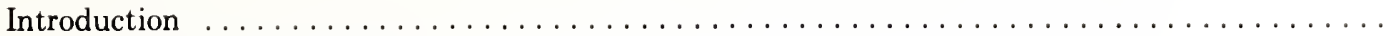

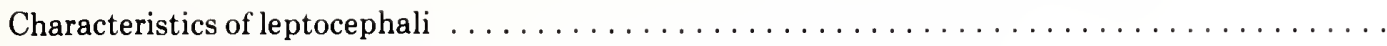

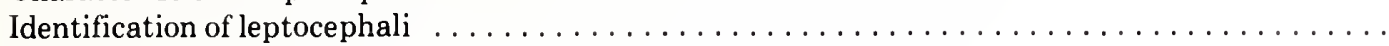

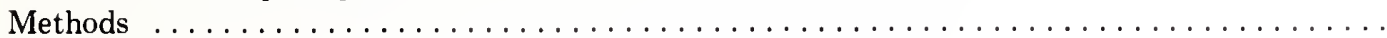

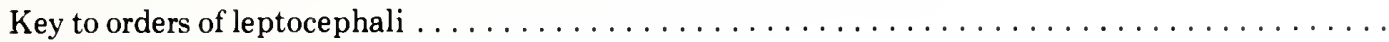

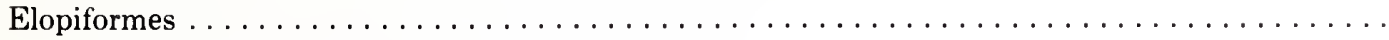

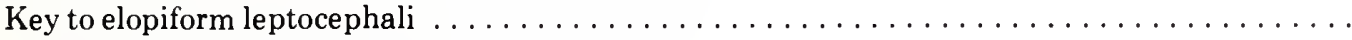

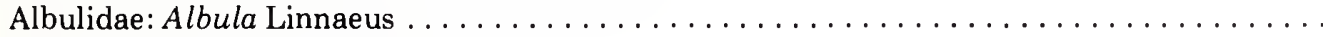

Albulidae: Pterothrissus Hilgendorf $\ldots \ldots \ldots \ldots \ldots \ldots \ldots \ldots \ldots \ldots \ldots \ldots \ldots \ldots \ldots$

Elopidae: Megalops Lacépède

Elopidae: Elops Linnaeus

Anguilliformes

Synaphobranchidae: Dysomminae ........................

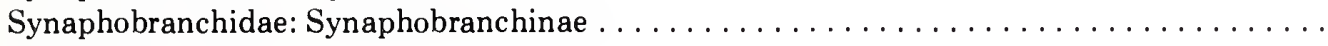

Synaphobranchidae: Simenchelyinae $\ldots \ldots \ldots \ldots \ldots \ldots \ldots \ldots \ldots \ldots \ldots \ldots \ldots \ldots \ldots$

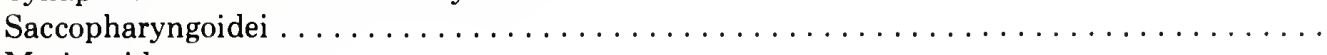

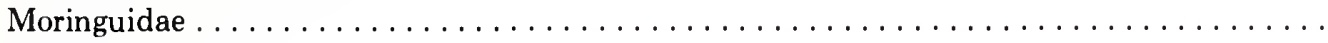

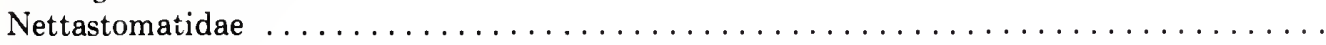

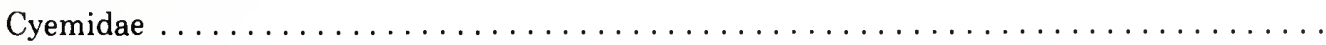

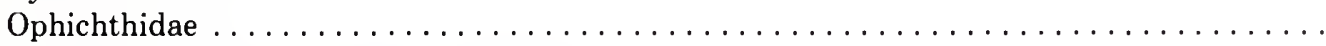

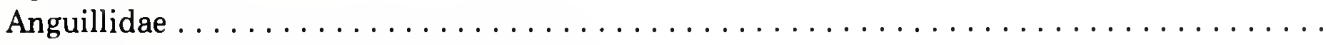

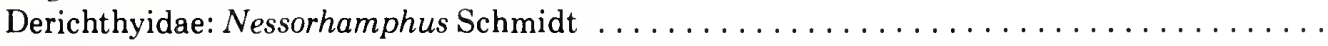

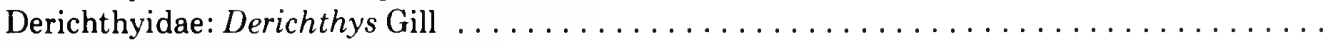

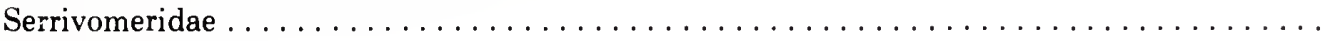

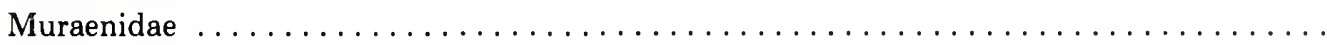

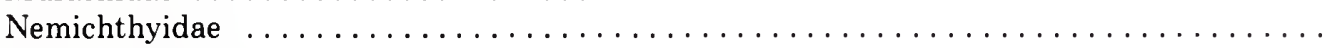

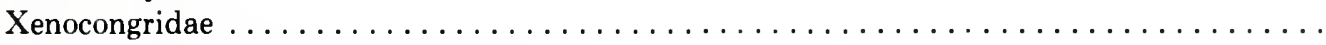

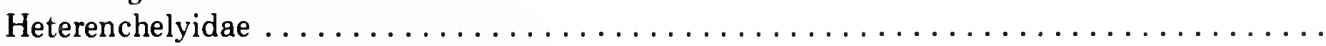

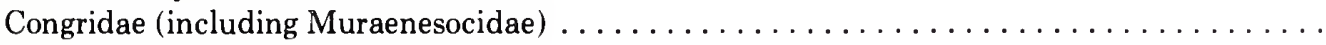

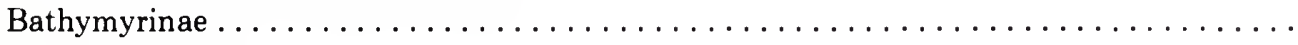

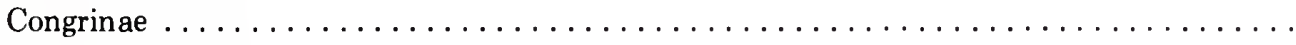

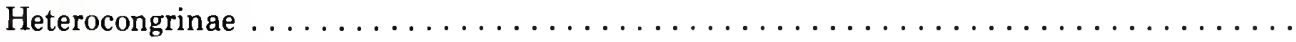

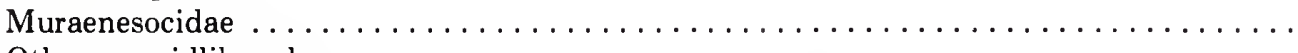

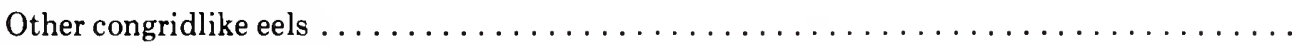

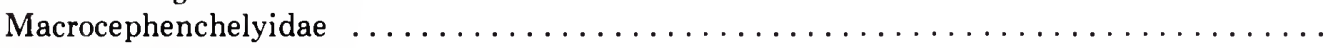

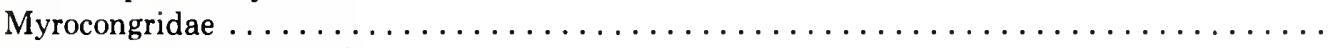

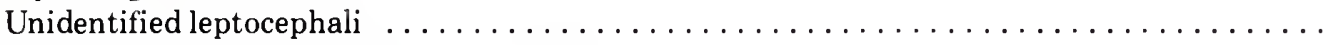

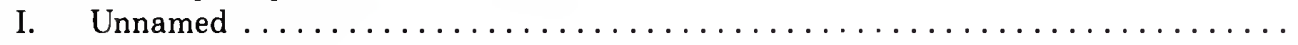

II. Unnamed

III. Ascomana Castle

IV. Thalassenchelys Castle and Raju

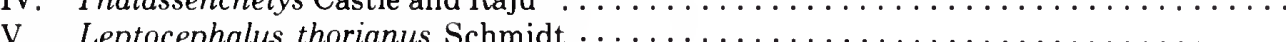

Notacanthiformes

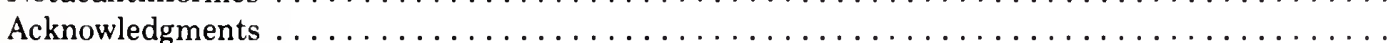

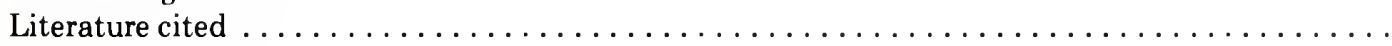

Appendix

\section{Figures}

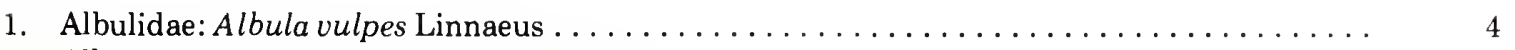

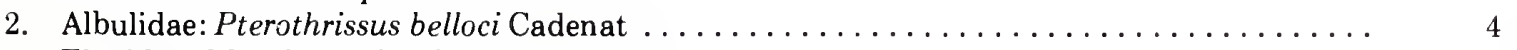

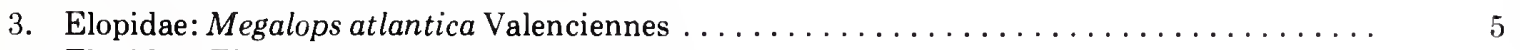

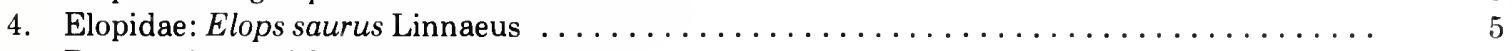

5. Dysomminae, without rostral filament $\ldots \ldots \ldots \ldots \ldots \ldots \ldots \ldots \ldots \ldots \ldots \ldots \ldots \ldots$ 
6. Dysomminae, with rostral filament: Leptocephalus proboscideus Lea $\ldots \ldots \ldots \ldots \ldots \ldots$

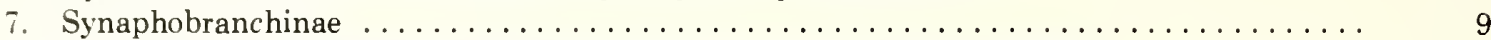

8. Saccopharyngoidei, Eurypharyngidae: Eurypharynx pelecanoides Vaillant ........... 9

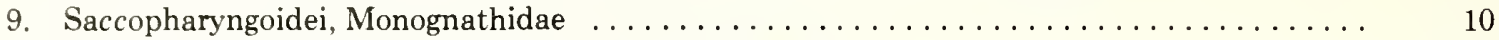

10. Moringuidae: Moringua edwardsi (Jordan and Bollman) $\ldots \ldots \ldots \ldots \ldots \ldots \ldots \ldots \ldots \ldots$

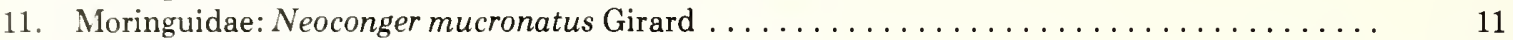

12. Nettastomatidae: Nettastoma-Metopomycter group ................... 11

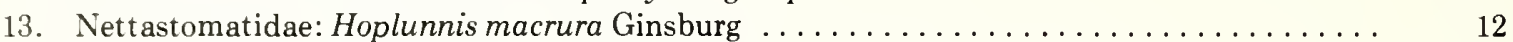

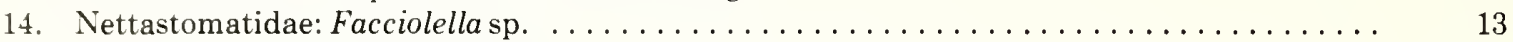

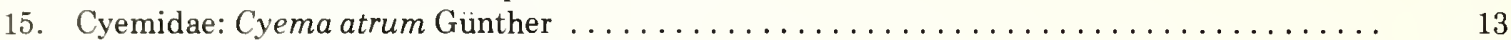

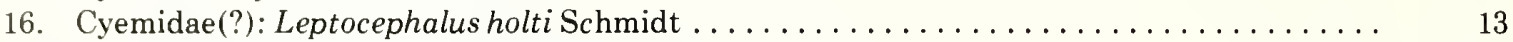

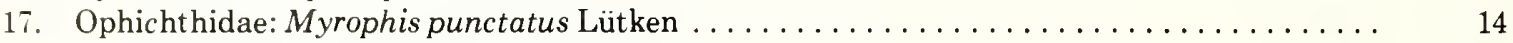

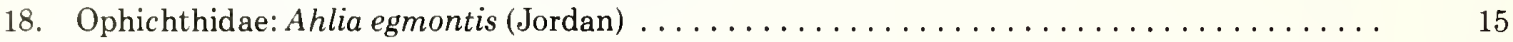

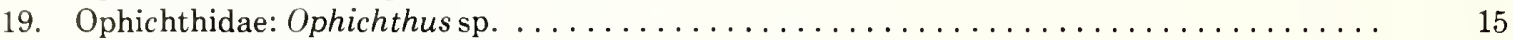

20. Ophichthidae: Pisodonophis cruentifer Goode and Bean $\ldots \ldots \ldots \ldots \ldots \ldots \ldots \ldots \ldots$

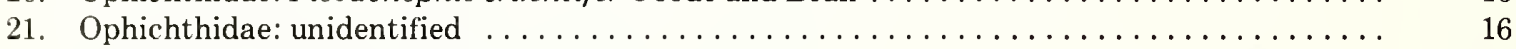

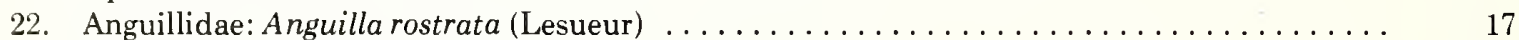

23. Derichthyidae: Nessorhamphus ingolfianus $(\mathrm{Schmidt}) \ldots \ldots \ldots \ldots \ldots \ldots \ldots \ldots \ldots \ldots$

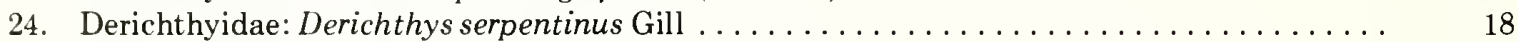

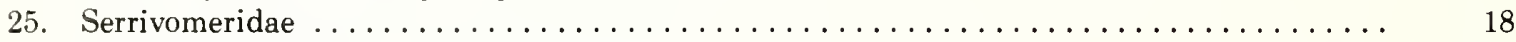

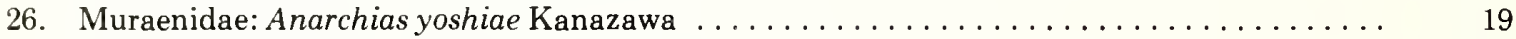

27. Muraenidae: Channomuraena vittata (Richardson) $\ldots \ldots \ldots \ldots \ldots \ldots \ldots \ldots \ldots \ldots \ldots$

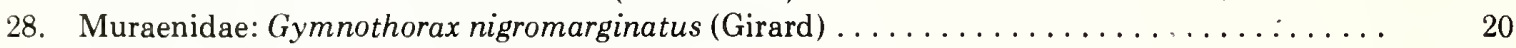

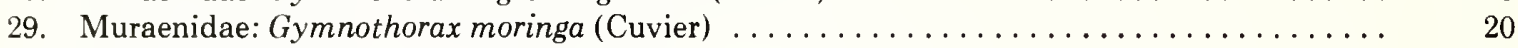

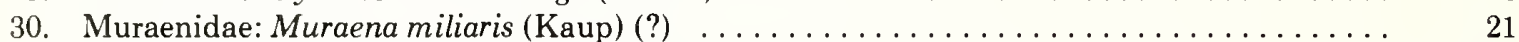

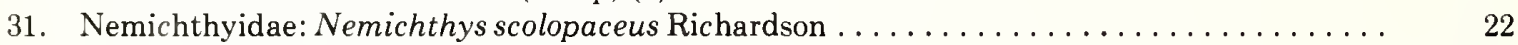

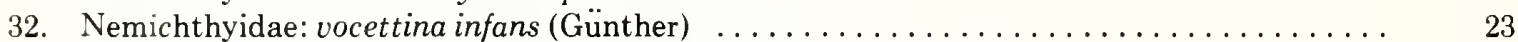

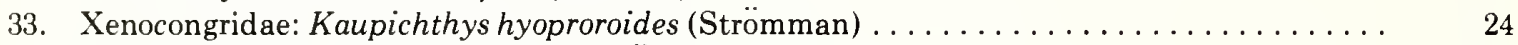

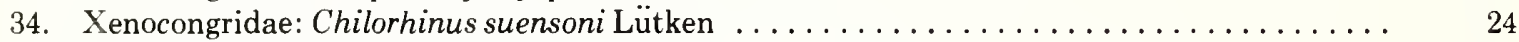

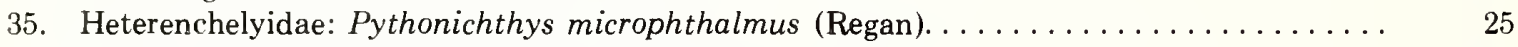

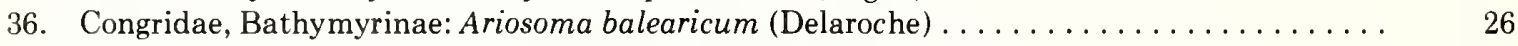

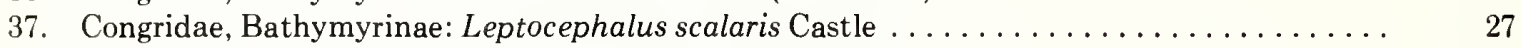

38. Congridae, Bathymyrinae: Leptocephalus macrenteron D'Ancona . . . . . . . . . . . . 27

39. Congridae, Bathymyrinae: Paraconger caudilimbatus (Poey) . . . . . . . . . . . . . . . . 27

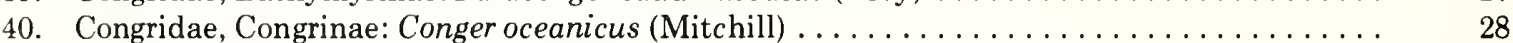

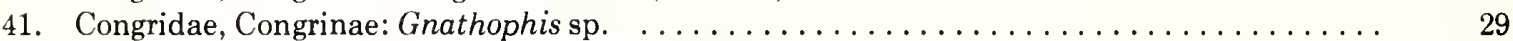

42. Congridae, Congrinae: Uroconger syringinus Ginsburg $\ldots \ldots \ldots \ldots \ldots \ldots \ldots \ldots \ldots \ldots \ldots$

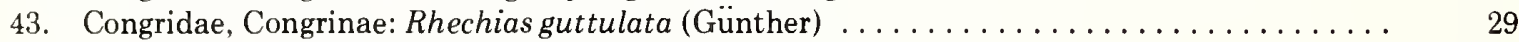

44. Congridae, Congrinae: Hildebrandia flava (Goode and Bean) $\ldots \ldots \ldots \ldots \ldots \ldots \ldots \ldots \ldots .30$

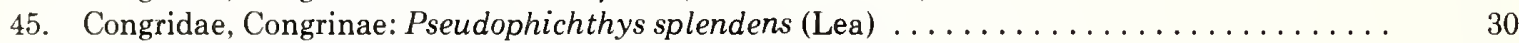

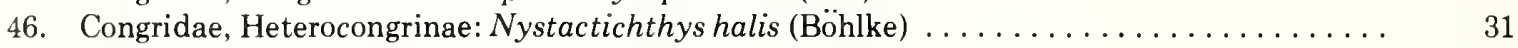

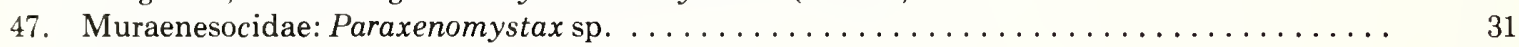

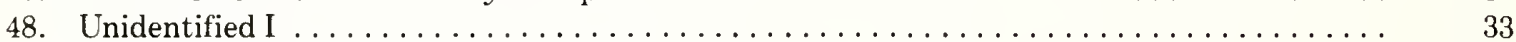

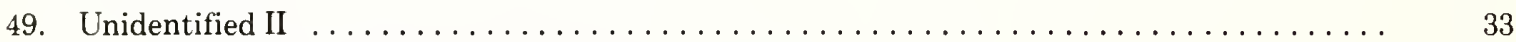

50. Unidentified III: Ascomana eximia Castle, $29 \mathrm{~mm}$ TL . . . . . . . . . . . . . . . . . . . 34

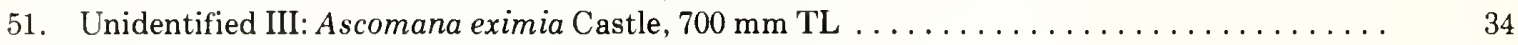

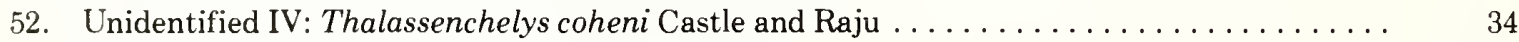

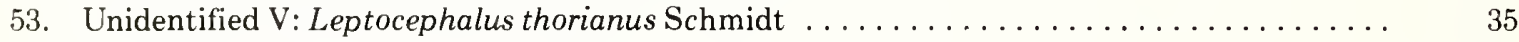

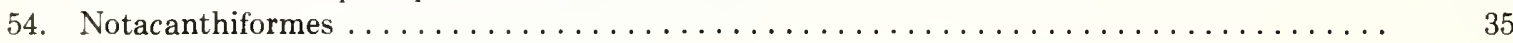




\title{
Guide to the Leptocephali (Elopiformes, Anguilliformes, and Notacanthiformes)
}

\author{
DAVID G. SMITH ${ }^{1}$
}

\begin{abstract}
Elopiform leptocephali have a large, forked caudal fin, and nonconfluent dorsal and anal fins. Anguilliform leptocephali have a small, rounded caudal fin confluent with the dorsal and anal fins and lack pelvic fins at all stages of development. In the Anguilliformes, larvae of the Macrocephenchelyidae, Myrocongridae, and the subfamily Simenchelyinae of the Synaphobranchidae are unknown, and five distinctive kinds of leptocephali cannot be identified to family. Notacanthiform leptochphali are extremely elongate, have a single caudal filament rather than a true caudal fin, and have a short dorsal fin. Three kinds of notacanthiform larvae are known (Tilurus, Tiluropsis, and Leptocephalus giganteus) that cannot yet be identified below the ordinal level.
\end{abstract}

\section{INTRODUCTION}

The current interest in ichthyoplankton has generated a need for reliable guides to the identification of the various groups. Among these are the leptocephali, the characteristic larval forms of the fishes of the orders Elopiformes, Anguilliformes, and Notacanthiformes. Leptocephali are collected with some frequency in tropical and subtropical oceanic waters, but their identification has always been a problem, largely because the literature is scattered and the taxonomy of the adults is uncertain. In recent years much progress has been made in our knowledge of eels and related groups, both larvae and adults, and the point has been reached where a comprehensive guide to the leptocephali is possible.

This guide differs from others in the series in that it is a guide primarily to families and genera rather than to species. Although many larvae remain unidentifiable to species, most can be readily identified to family and often to genus, and it is on this level that such a guide can be most useful. Therefore, the reader should bear in mind that this guide is not a final statement, but rather a point of beginning. It is an attempt to assemble in one place current knowledge relating to the identification of leptocephali.

\section{CHARACTERISTICS OF LEPTOCEPHALI}

Leptocephali have an elongate, highly compressed, nearly transparent body. A series ov V- or W-shaped myomeres covers most of the lateral area of the body. A transparent area extends dorsally and ventrally from the myomeres. The head is small compared with the body. Rudiments of the dorsal, anal, and pectoral fins are present in all leptocephali. Pelvic fins are present in elopi-

\footnotetext{
'The Marine Biomedical Institute, University of Texas Medical Branch, 200 University Boulevard, Galveston, TX 77550.
}

form and notacanthiform larvae, and a caudal fin is present in elopiform and anguilliform larvae. The gut lies on the ventral margin. In all elopiform and notacanthiform larvae and some eel larvae it is a simple, straight tube. In many eel larvae, however, the gut has characteristic swellings, arches, or other modifications that can be useful taxonomic features. Pigmentation is present in the form of melanophores. The epidermis and myomeres are thin, and most of the interior of the body is filled with a mucinous material, medial to the myomeres. The notochord, the spinal nerve cord, and the dorsal aorta lie along the central axis of the body. The kidney is a linear structure lying along the top of the gut. A series of vertical blood vessels extend between the aorta and the gut and kidney. The posteriormost vertical blood vessel enters the posterior end of the kidney. Although heart and blood vessels are present and functional, no hemoglobin is formed until metamorphosis. The eyes and olfactory organs are well developed, and the portions of the brain associated with these functions are equally well developed. Strong, forwardly inclined, fanglike teeth are present in both upper and lower jaws. These are not homologous with the definitive teeth and disappear at metamorphosis.

Leptocephali grow larger before metamorphosing than most other larval fishes. Lengths of $50-100 \mathrm{~mm}$ are common, and some forms grow even larger. Certain notacanthiform larvae reach lengths of at least $1,800 \mathrm{~mm}$ (Nielsen and Larsen 1970).

Leptocephali commonly spend several months in the plankton. The larva of the European freshwater eel, Anguilla anguilla, is known to take about $3 \mathrm{yr}$ from hatching to metamorphosis (Schmidt 1925). During this time, the leptocephalus undergoes a considerable increase in size without much change in basic structure. Then in a matter of a few days to 2 wk the leptocephalus transforms into a juvenile and takes up the habitat and way of life of the adult (Rasquin 1955; personal observation). 


\section{IDENTIFICATION OF LEPTOCEPHALI}

The Elopiformes and Notacanthiformes are both small groups and their larvae show relatively little variety in form. Elopiform larvae are identified primarily by the relative positions of the dorsal and anal fins, pigmentation, shape of the head, and number of myomeres. Several kinds of notacanthiform larvae can be distinguished, mainly by the shape of the head and eye, but they cannot yet be identified with known adults.

The Anguilliformes, the true eels, is a much larger and more diverse group, and shows much more variety in all characters. Important characters in identifying eel larvae are general body shape, length and form of the gut (long or short, a simple tube or with swellings or arches), form of the head and snout, form of the tail, pigmentation (distribution of melanophores), position of the vertical fins, position of the last vertical blood vessel, number of myomeres (total, predorsal, and preanal), and number of dorsal and anal fin rays. Families and genera, or groups of genera or groups of species, can be characterized by combinations of these features. At the species level, and occasionally above it, the number of myomeres is the most important character.

Of all the characters mentioned above, the only one universally carried through metamorphosis is the correspondence between the number of myomeres in the larva and the number of vertebrae in the adult. Because there are likely to be several eels in one area with similar vertebral counts, however, it is necessary to narrow the identification down to family or genus before attempting to match myomeres with vertebrae.

A few other characters are sometimes useful in linking larvae with adults. In some species, traces of larval pigmentation persist for a time in the juvenile. Eventually this disappears, but while it lasts it provides a good link. The position of the last vertical blood vessel in the larva is related, at least approximately, to the first caudal vertebra in the adult. The surest way to link a larva with an adult is to find metamorphosing specimens, which combine the characters of the adult with those of the larva.

\section{METHODS}

The leptocephali of the three orders are treated somewhat differently. The Elopiformes is a small and wellcharacterized group containing only two families. It is keyed out directly to genus. The eel larvae are treated mainly by family, with a few exceptions. The gulper eels comprise three families but are treated as a unit, the suborder Saccopharyngoidei. The Muraenesocidae is included with the related Congridae. The two subfamilies of the Synaphobranchidae are treated separately, as are the two genera of the Derichthyidae. The remaining 11 families are treated individually. Several distinctive but as yet unidentifiable larvae are treated separately at the end of the Anguilliformes section, but are not included in the key. Notacanthiform larvae cannot yet be identified beyond the ordinal level and are treated as a unit.
The key to Anguilliform leptocephali should be used with some caution. Some representatives of a group may not show very well some of the important characters of that group. Reference should always be made to the family account and the illustrations, and the keys should be considered only as auxilliary. The key includes only those forms belonging to a known family group.

Some rather vague terms are used in the descriptions. Because of the great variability of many characters shown in the larger groups, precision is impossible. Terms such as "moderte," "elongate," "pointed," "sharp," "blunt," etc. serve to indicate predominant trends and will be clarified by referring to accompanying illustrations and to actual specimens. Lateral pigment refers to pigment anywhere on the side of the body. Ventral pigment is that on the intestine or the ventral midline of the body posterior to the intestine.

The keys and descriptions have certain limitations. They do not apply to very young larvae or, in most cases, to metamorphosing specimens. Distinguishing characters develop with growth, and larvae less than about 10 $\mathrm{mm}$ become difficult to identify. At the other end of the growth scale, important characters are often lost at the onset of metamorphosis. Damaged or faded specimens will be difficult to identify because of the importance of such characters as pigmentation and position of fins. Occasionally even a specimen in good condition may not key out. The boundaries of some families are not clearly defined, and the larvae may show more variation than is now recognized. Several leptocephali are described in this paper that cannot be identified to family, and others may be found in the future.

Each family account begins with a description of the main characters of that family. A brief summary of the most important of these characters follows, along with a discussion of any problems or confusion that might arise in identifying those particular larvae. Where larvae of certain genera or species of that family are known, they are described. The species of each family or genus occurring in the western North Atlantic are listed, with the number of myomeres and vertebrae following each species name in parentheses. At the end of each account selected references are given. The literature cited is not intended to be complete, but it does give basic information as well as references to further sources. The reader is referred especially to Castle's (1969b) "An Index and Bibliography of Eel Larvae," which contains a wealth of information on literature and nomenclature, as well as listing all the species of eels whose larvae had been described up to the time of publication.

Representative examples of each group are illustrated. In addition to a whole view, enlarged views are shown of the head and other important characters. Original drawings were made from specimens chosen for their representative appearance and state of preservation. These specimens are indentified in the figure captions by vessel and station number. Abbreviations and institu-tions where specimens are deposited are as follows: $\mathrm{MBI}=$ Marine Biomedical Institute, Galveston, Tex.; $\mathrm{CI}=$ Columbus Iselin, GS = James $M$. Gillis, $\mathrm{P}=$ John Elliott 
Pillsbury, all Rosenstiel School of Marine and Atmospheric Science, University of Miami, Miami, Fla.; ALB
IV = Albatross IV, National Marine Fisheries Service Miami Laboratory.

\section{KEY TO ORDERS OF LEPTOCEPHALI}

B1 Caudal fin small and rounded, continuous with dorsal and anal . . . . . . . . Anguilliformes (Figs. 5-53)

B2 Caudal fin absent, instead a single filament; dorsal fin short, located anteriorly . . . Notacanthiformes (Fig. 54)

\section{ELOPIFORMES (Figs. 1-4)}

Large, forked caudal fin; short dorsal and anal fins not confluent with caudal fin; pectoral fins well developed; pelvic fins present but much smaller than pectorals in larvae nearing metamorphosis; gut a simple straight tube; pigmentation variable; 19 principal caudal rays.

Elopiform leptocephali do not vary widely in major characters. The main differences are in the position of the vertical fins, the shape of the head, and the number of myomeres. Four genera are recognized representing two families (three if the Megalopidae is recognized).

\section{Key to Elopiform Leptocephali}

A1 Origin of anal fin well behind dorsal fin, by a distance exceeding the length of anal fin base; la-

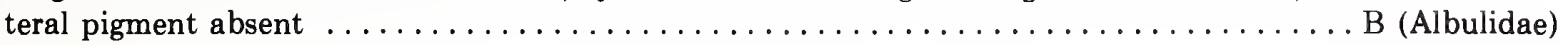

A2 Origin of anal fin under dorsal fin or close behind it, by a distance not exceeding the length of

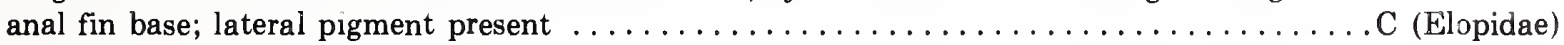

B1 Distance between verticals from posterior edge of dorsal fin to anal fin origin about 2.5 times

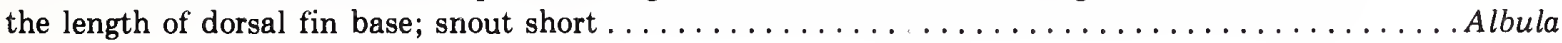

B2 Distance between verticals from posterior edge of dorsal fin to anal fin origin about 6-7 times the length of dorsal fin base; snout more prolonged $\ldots \ldots \ldots \ldots \ldots \ldots \ldots \ldots \ldots$. . . . . . . . . . . . .

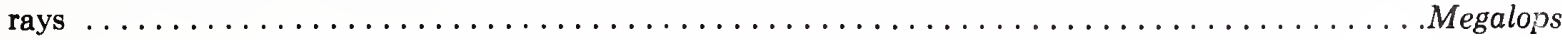

Origin of anal fin under posterior end of dorsal fin or slightly behind; head depressed; more aor-

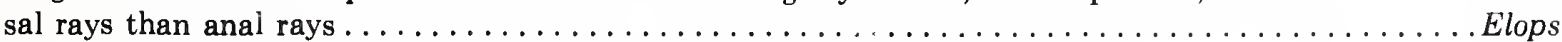

\section{Albulidae: Albula Linnaeus (Fig. 1)}

Distance between posterior edge of dorsal fin and anal fin origin about 2.5 times the length of dorsal fin base; vent very far back, almost under hypural; head blunt, not depressed, with short snout; pigment confined to ventral margin of myomeres on each side, consisting of a row of small melanophores forming an interrupted line extending length of gut; maximum size before metamorphosis $60-70 \mathrm{~mm}$ standard length (SL).

At metamorphosis, the anal fin begins to move forward, but never as far relative to the dorsal fin as in Elops and Megalops.

Two species of Albula are currently recognized. Albula vulpes Linnaeus (number of myomeres-number of vertebrae: 68-74), is found around the world in tropical seas and A. nemoptera (Fowler) (77-80) is restricted to certain places in the tropical western Atlantic and eastern Pacific.

References: Alexander (1961), Eldred (1967a), Rivas and Warlen (1967). 
A
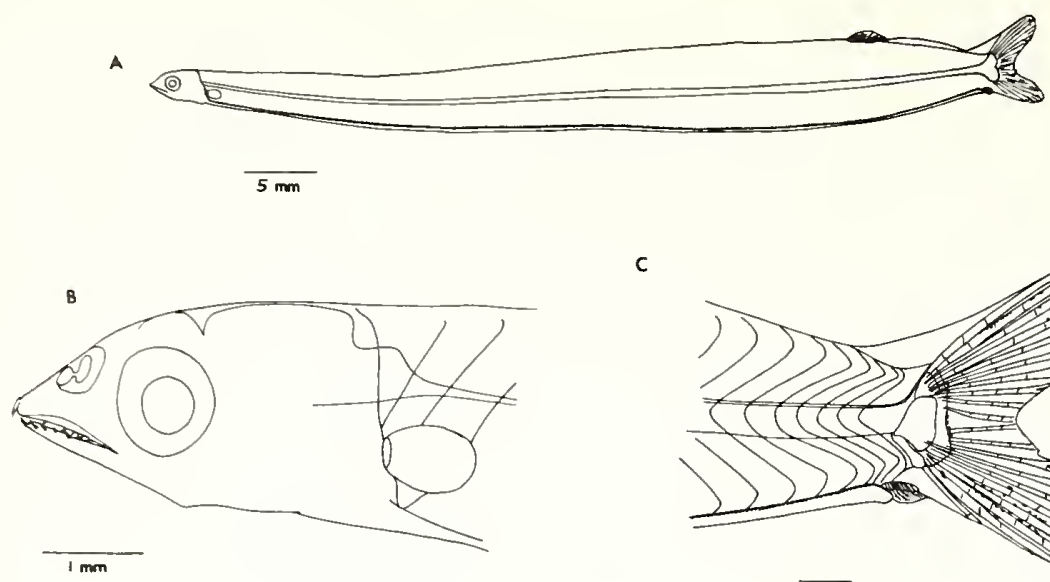

c

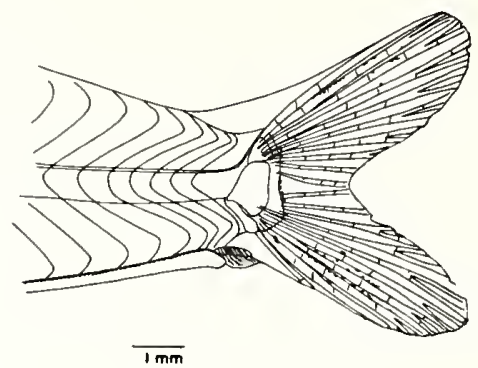

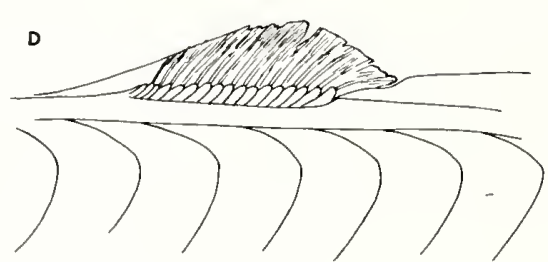

Figure 1.-Albulidae: Albula vulpes Linnaeus, $61 \mathrm{~mm}$ SL, CI 90 . A. Whole view. B. Head. C. Tail. D. Dorsal fin.

\section{Albulidae: Pterothrissus Hilgendorf (Fig. 2)}

Body elongate; distance between posterior end of dorsal fin and anal fin origin about 6-7 times the length of dorsal fin base, vent nearly under hypural; snout somewhat prolonged; a row of elongated melanophores along ventral margin of myomeres extending length of gut; maximum size at least $124 \mathrm{~mm}$.

Larvae of Pterothrissus are collected much more infrequently than those of Albula, and can be distinguished from them by the more elongate body, the longer snout, and the greater distance between the dorsal and anal fins.

Two species are known: Pterothrissus belloci Cadenat (85-92) occurs off west Africa and P. gissu Hilgendorf is found off Japan. Larvae of the former species have been described; those of the latter have not.

References: Smith (1966), Richards (1969).

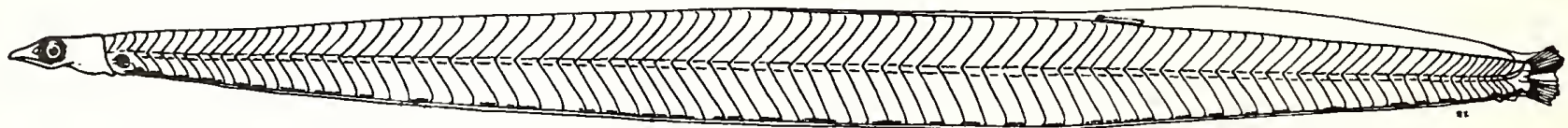

Figure 2.- Albulidae: Pterothrissus belloci Cadenat, $123.9 \mathrm{~mm}$ SL, from Richards (1969).

\section{Elopidae: Megalops Lacépède (Fig. 3)}

Origin of anal fin under dorsal fin; head not markedly depressed; ventral pigment consisting of elongate melanophores on ventral margin of myomeres; lateral pigment consisting of small melanophores on myosepta below midlateral line; maximum size $20-30 \mathrm{~mm}$.

The anal fin origin is distinctly farther forward relative to the dorsal fin in Megalops than in Elops, generally under the middle or anterior part of the dorsal fin. In Elops it is either behind the dorsal fin or under the posterior end. The head is not depressed in Megalops as it usually is in Elops. Megalops has fewer dorsal rays (9-16) than anal rays (16-25), whereas in Elops the dorsal rays are more numerous than the anal rays (20-25 vs. 14-17) (Wade 1962; Hildebrand 1963; Richards 1969). Very small larvae of Megalops have a distinct swelling in the posterior end of the gut; it becomes less obvious with growth. Larvae of Megalops are the smallest of the elopiform leptocephali.

There are two species of Megalops. Megalops atlantica Valenciennes (53-57), the tarpon, is found on both sides of the Atlantic. Megalops cyprinoides (Broussonet) (65-67), the oxeye, is found in the Indo-Pacific from east Africa to the Philippines and Australia.

References: Wade (1962), Eldred (1967b, 1972), Richards (1969). 
A

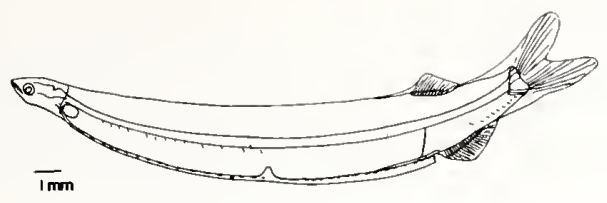

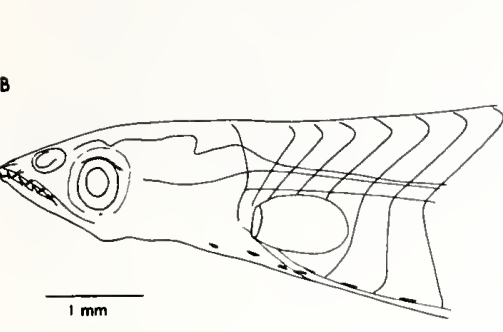

D

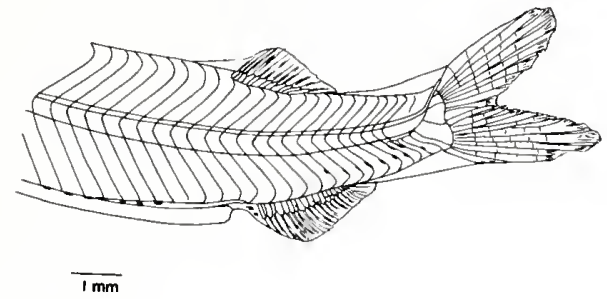

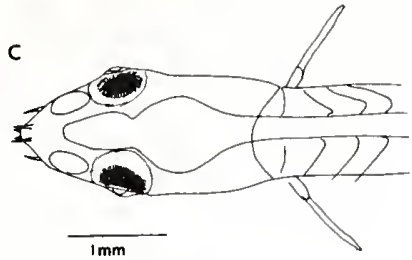

Elopidae: Elops Linnaeus (Fig. 4)
Figure 3.-Elopidae: Megalops atlantica Valenciennes, $21 \mathrm{~mm}$ SL, MBI 170 . A. Whole view. B. Head, lateral view. C. Head, dorsal view. D. Tail.

Origin of anal fin slightly behind level of dorsal fin, by a distance not exceeding length of anal fin base; head depressed; ventral pigment consisting of elongate melanophores on ventral margin of myomeres extending length of gut; lateral pigment consisting of small melanophores just below midlateral line; a series of melanophores just above ventral flexure of myomeres between anal and caudal fins; maximum size $40-50 \mathrm{~mm}$.

This genus is cosmopolitan and contains more species than the other elopiform genera, about seven. One species is found in the western Atlantic, E. saurus Linnaeus (73-80).

References: Gehringer (1959), Eldred and Lyons (1966), Richards (1969).

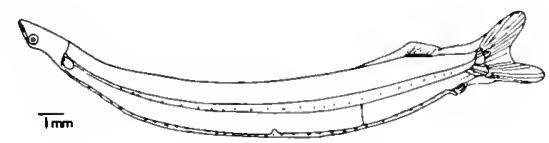

C

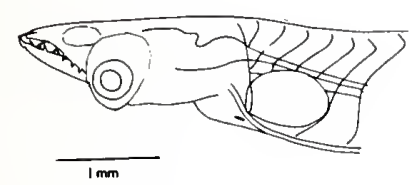

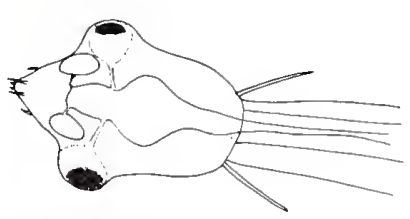

$1 \mathrm{~mm}$

D

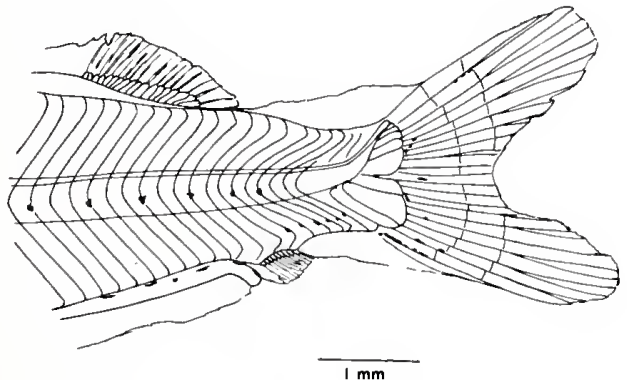

Figure 4.-Elopidae: Elops saurus Linnaeus, $20 \mathrm{~mm}$ SL, MBI 67. A. Whole view. B. Head, lateral view. C. Head, dorsal view. D. Tail. 
Body variable; caudal fin small and rounded, continuous with dorsal and anal fins (some ophichthids have secondarily lost the caudal fin); pelvic fins always absent.

The great majority of leptocephali are eel larvae. Twenty-two families are recognized here. The Muraenesocidae is problematical; it is included here under the Congridae, to which it is related and which its larvae (those that are known) closely resemble. Two subfamilies of the Synaphobranchidae-the Synaphobranchinae and Dysomminae-are treated separately here because the larvae are markedly different. The two genera of the Derichthyidae are also treated separately to facilitate comparison with the Serrivomeridae. The three families of gulper eels are treated as one unit, the Saccopharyngoidei. The remaining 11 families are covered individually. A few distinctive but unidentified forms are treated separately at the end of the section. Larvae of the Macrocephenchelyidae and Myrocongridae are unknown.

\section{Key to Anguilliform Leptocephali}

Intestinal pigment present; gut with several small thickenings; rostral filament sometimes

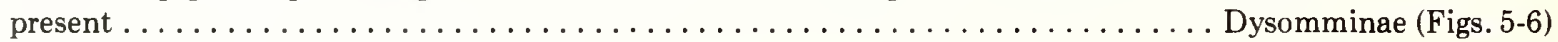
Intestinal pigment absent; gut a simple straight tube; rostral filament absent . . . Synaphobranchinae (Fig. 7)

Head deep with elongate hyomandibula; gut with a single pigmented thickening at posterior

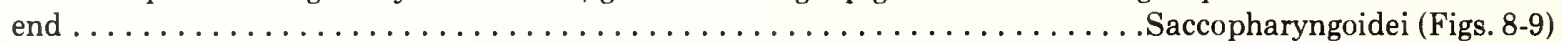

Head and jaw suspension normal

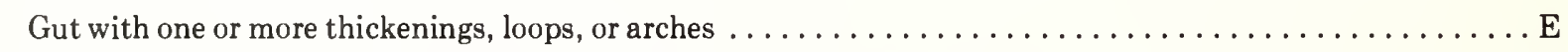

Gut a simple straight tube without thickenings, loops, or arches $\ldots \ldots \ldots \ldots \ldots \ldots \ldots \ldots \ldots$

Gut with a single thickening or arch at posterior end $\ldots \ldots \ldots \ldots \ldots$ Moringuidae (Figs. 10-11)

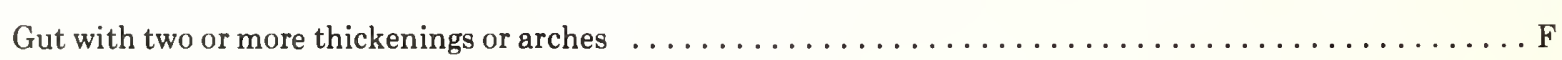

Gut with two thickenings $\ldots \ldots \ldots \ldots \ldots \ldots \ldots \ldots \ldots \ldots \ldots \ldots$ Nettastomatidae (Part) (Figs. 12-13)

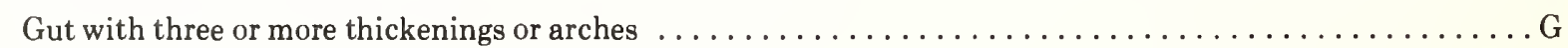

Body very deep; myomeres about $80 \ldots \ldots \ldots \ldots \ldots \ldots \ldots \ldots \ldots \ldots \ldots \ldots \ldots \ldots \ldots \ldots \ldots \ldots \ldots$ Cyemidae (Figs. 15-16)

Body moderately elongate; myomeres more than $100 \ldots \ldots \ldots \ldots \ldots$. . . . . . . . . 17-21)

Melanophores absent

Anguillidae (Fig. 22) 
J1 Pectoral fin greatly reduced; gut less than half standard length; dorsal and anal fin restricted to tip of caudal region . . . . . . . . . . . . . . . . . . . . Muraenidae (in part: Anarchias)

J2 Pectoral fin well developed; gut more than half standard length; dorsal and anal fins not

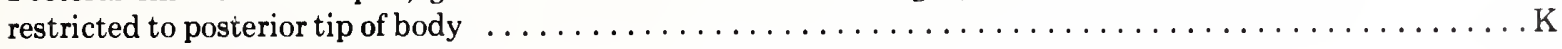

K1 Last vertical blood vessel around myomere 75-80; preanal myomeres more than $100 \ldots \ldots \ldots$

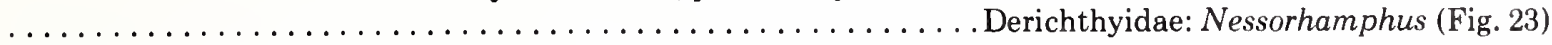

K2 Last vertical blood vessel at myomere 59-63; preanal myomeres 76-83 . . . . Derichthyidae: Derichthys (Fig. 24)

K3 Last vertical blood vessel at myomere 30-37; preanal myomeres about 89-125 . . . . . . Serrivomeridae (Fig. 25)

L1 Pectoral fin greatly reducedi; posterior nostril above level of middle of eye; tail generally

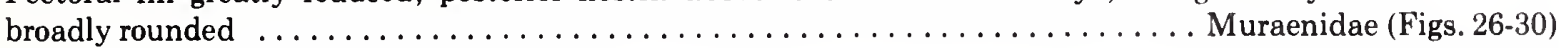

L2 Pectoral fin well developed; posterior nostril near or below level of middle of eye; tail generally

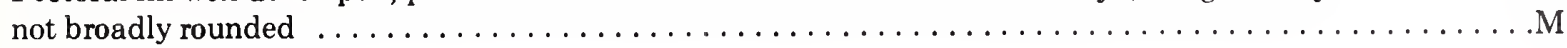

M1 Small but distinct deep-lying pigment spots along top of notochord; body elongate; ventral melanophores small, restricted to top of gut $\ldots \ldots \ldots \ldots \ldots \ldots \ldots \ldots \ldots \ldots \ldots \ldots$ Nemichthyidae (Figs. 31-32)

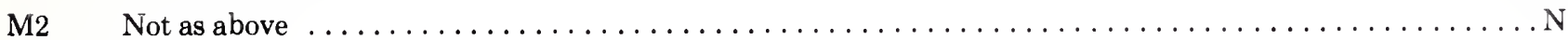

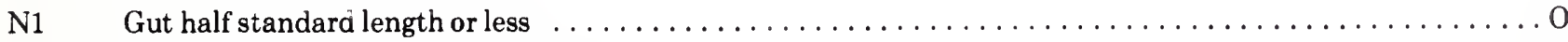

N2 Gut greater than half standard length $\ldots \ldots \ldots \ldots \ldots \ldots \ldots \ldots \ldots \ldots \ldots \ldots \ldots \ldots \ldots \ldots$

O1 Body narrow and elongce; head elongate .................tastomatidae (in part: Facciolella) (Fig. 14)

O2 Body moderately deep; head moderately short $\ldots \ldots \ldots \ldots \ldots \ldots \ldots \ldots \ldots$ Xenocongridae (Figs. 33-34)

P1 Head short and deep; no crescentıc patch of pigment below eye . . . . . . . . . Heterenchelyidae (Fig. 35)

P2 Head generally moderately elongate, snout more or less acute; those with short heads gener-

ally have crescentic patch of pigment below eye ........ Congridae (including Muraenesocidae) (Figs. 36-47)

\section{Synaphobranchidae: Dysomminae (Figs. 5-6)}

Gut about one-half to two-thirds standard length, with a series of small thickenings; head variable, rostral filament sometimes present; eye telescopic; nasal organ closer to snout tip than to eye; ventral pigment a series of rather large melanophores; maximum size usually about $100 \mathrm{~mm}$ (excluding the rostral filament), up to $200 \mathrm{~mm}$ in Leptocephalus rostratus Schmidt.

These distinctive larvae fall into two types, one with and one without a rostral filament. Each type contains several species, differentiated by pigmentation and myomere number. The larva of only one species, Dysomma brevirostre (Facciola), has been conclusively identified. The Dysomminae is a poorly known group and many species probably remain undescribed as adults. Seven species of larvae have been recorded from the western Atlantic, but none has been positively identified. Species recorded as adults from the wesiern Atlantic are Dysomma anguillare Barnard (119-130), Dysomma brevirostre (Facciolà) (195-204), Dysommina rugosa Ginsburg (126-134), Atractodenchelys phrix Robins and Robins (169-173), and Haptenchelys texis Robins and Martin (126-128).

References: Schmidt (1909), Grassi (1913), Lea (1913), D’Ancona (1928, 1931), Blache et al. (1970), Robins and Robins $(1970,1976)$, Smith (1974), Keiler (1976). 

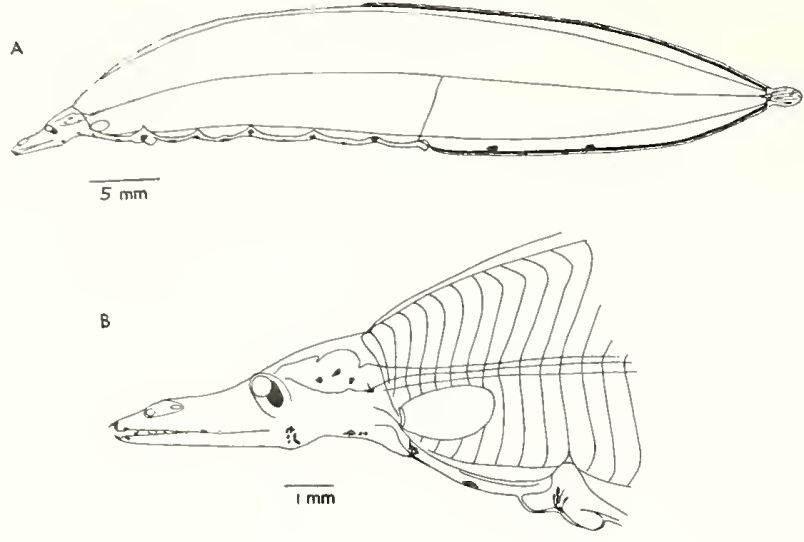

C

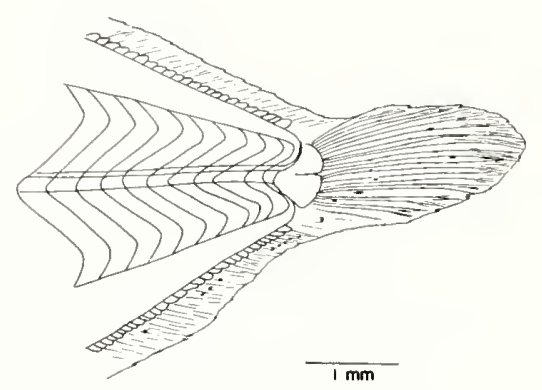

Figure 5.-Dysomminae, without rostral filament: $54 \mathrm{~mm}$ SL, MBI 47. A. Whole view. B. Head. C. Tail.
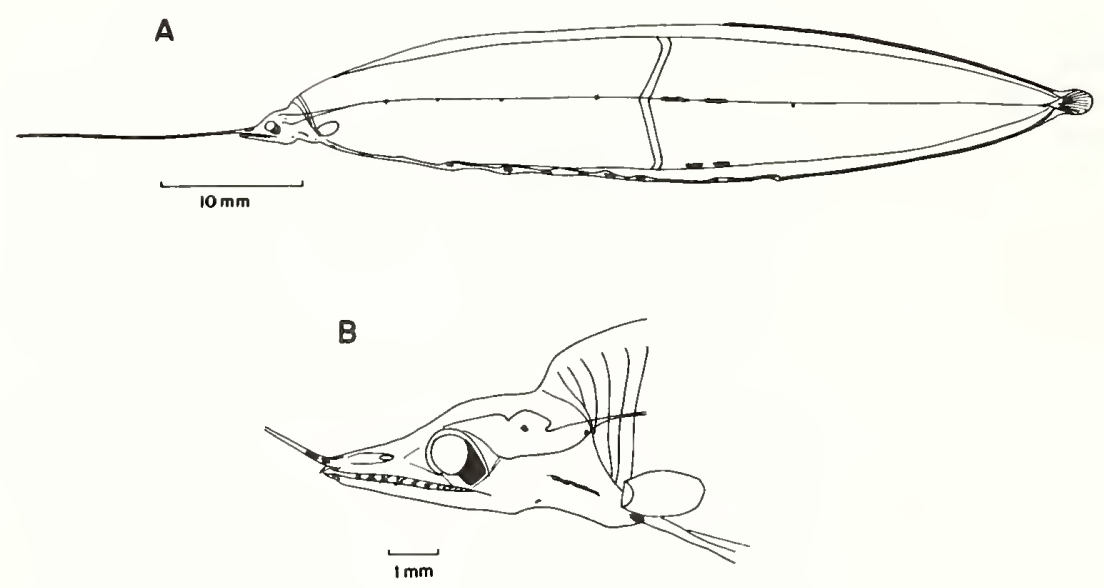

Figure 6.-Dysomminae, with rostral filament: Leptocephalus proboscideus Lea, $67 \mathrm{~mm}$ SL, from Smith (1974). A. Whole view. B. Head.

\section{Synaphobranchidae: Synaphobranchinae (Fig. 7)}

Gut without arches or thickenings, about three-fourths standard length; dorsal fin origin generally slightly anterior to level of vent; eye telescopic; central section of myomeres around spinal cord more opaque than dorsal and ventral parts, giving the effect of a broad white longitudinal stripe along the length of the body; no ventral pigment; lateral pigment generally conned to a few small melanophores near tail and on caudal fin; maximum size 130-170 mm.

Synaphobranchine larvae are easily recognized. The telescopic eye is found elsewhere among leptocephali only in the Dysomminae, and dysommines are easily distinguished by the prominent ventral pigmentation and the longer head. The broad white stripe formed by the opaque central section of the myomeres is found only in synaphobranchines.

The species of synaphobranchines show considerable overlap in vertebral numbers, making identification of larvae difficult. The following species occur in the western Atlantic: Synaphobranchus affinis Günther (128-139), S. brevidorsalis Günther (130-135), S. oregoni Castle (142-148), S. kaupi Johnson (146-150), Histiobranchus infernalis Gill (126140), and Ilyophis brunneus Gilbert (144-151). The boundary between the Synaphobranchinae and the Dysomminae is not clear, and it is conceivable that some species considered to be synaphobranchines may have dysommine-type larvae and vice-versa.

References: Bruun (1937), Castle (1964a), Robins (1971). 
A

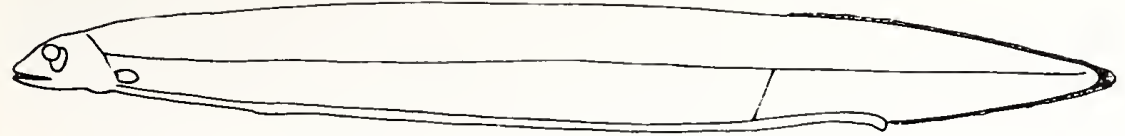

$5 \mathrm{~mm}$

B

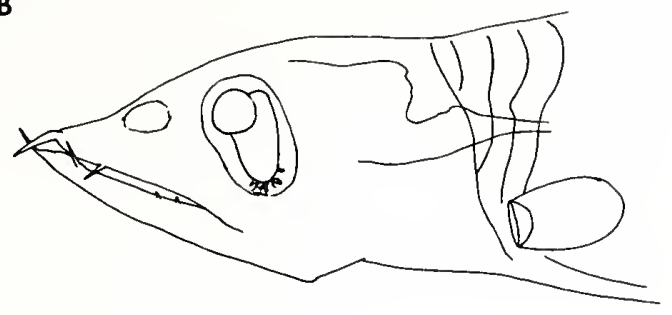

Figure 7.-Synaphobranchinae. A. Whole view, $84 \mathrm{~mm}$ SL, adapted from Bruun (1937). B. Head, 29 mm SL, Alb IV 73-2 stn. 70.

$\mathrm{l} \mathrm{mm}$

Synaphobranchidae: Simenchelyinae

Formerly treated as a family, this monotypic group was placed in the Synaphobranchidae by Robins and Robins (1976). One late metamorphic specimen of Simenchelys parasiticus Gill (121-125) was described by Raju and Rosenblatt (1971), but it was too far advanced to show any larval characters. No trace of pigment was present. Since all the other known larvae of the Synaphobranchidae have a telescopic eye, it is reasonable to expect that Simenchelys may show this character too.

Saccopharyngoidei (Figs. 8-9)

A

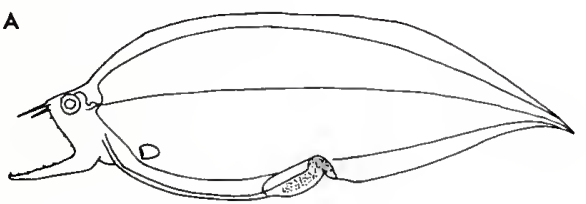

$1 \mathrm{~mm}$

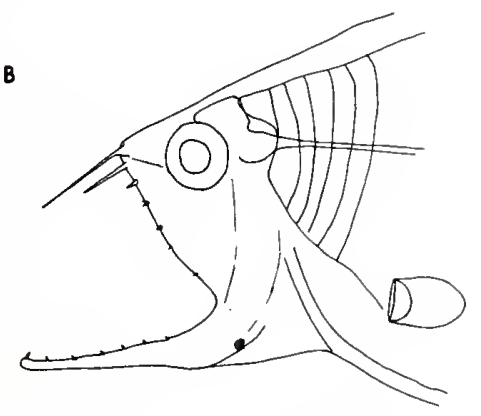

$\mathrm{Imm}$

C

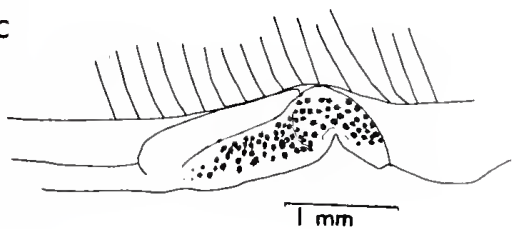

Figure 8.-Saccopharyngoidei, Eurypharyngidae: Eurypharynx pelecanoides Vaillant. A. Whole view, $19 \mathrm{~mm} \mathrm{SL}$, Alb IV 73-2 stn. 4. B. Head, $14 \mathrm{~mm} \mathrm{SL}$, Alb IV 73-2 stn. 19. C. Anal region, same. 

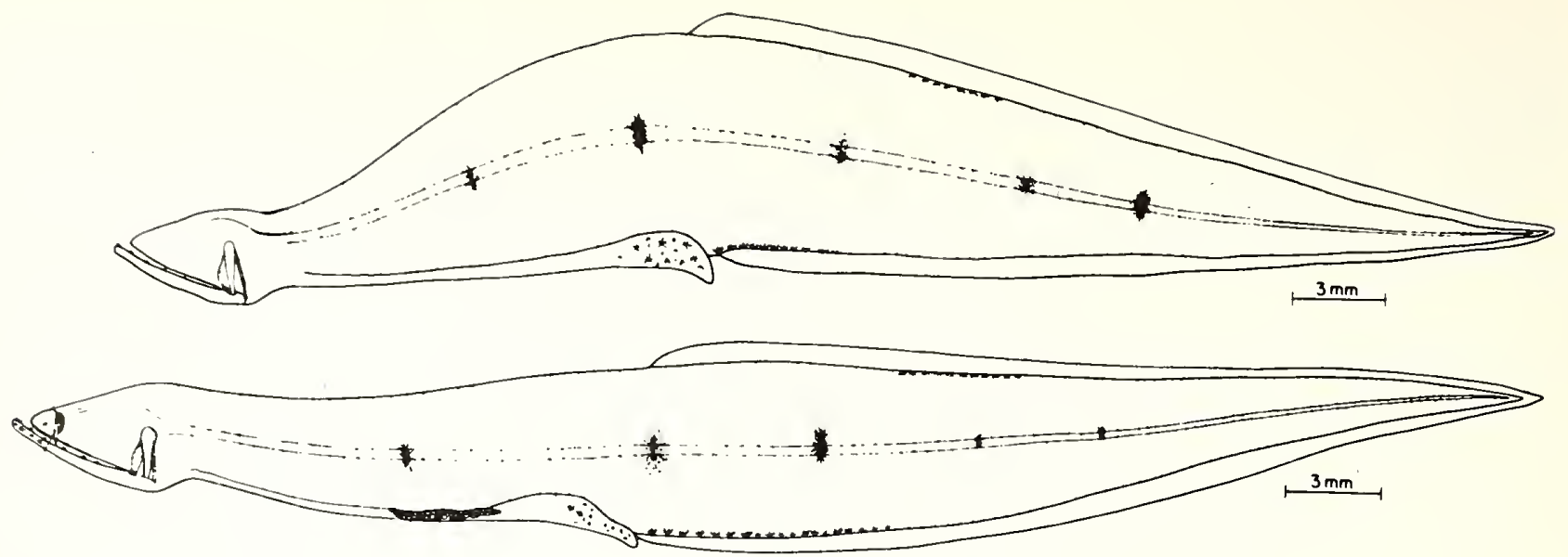

Figure 9.-Saccopharyngoidei, Monognathidae. A. $42 \mathrm{~mm} \mathrm{SL}$. B. $48 \mathrm{~mm}$ SL. From Raju (1974a).

Body short and deep; tail pointed; gut one-half to two-thirds standard length with a single pigmented thickening at posterior end; head short and deep with elongate hyomandibular element foreshadowing exaggerated jaw suspension of adults; ventral pigment confined to posterior thickening of gut; large lateral melanophores present in Monognathidae, absent in others; maximum size $30-40 \mathrm{~mm}$.

The highly modified bathypelagic gulper eels of the families Eurypharyngidae, Saccopharyngidae, and Monognathidae are customarily placed in a separate suborder, the Saccopharyngoidei, to distinguish them from the rest of the eels, the Anguilloidei. Their larvae are typical eel leptocephali except for the modified jaw suspension. Monognathid larvae are distinguished by several large lateral melanophores (Fig. 9). Larvae of the Eurypharyngidae and Saccopharyngidae lack lateral pigment (Fig. 8). Based largely upon the difference in vertebral numbers, it seems that the larva described by Schmidt (1909) as Leptocephalus latissimus (170-250) belongs to Saccopharynx Mitchill (138-250), while Leptocephalus pseudolatissimus of Bertin (103-125) is the larva of Eurypharynx Vaillant (97-125). A single species of Eurypharynx, E. pelecanoides Vaillant, is currently recognized around the world. Four species of Saccopharynx were recognized in the most recent revision (Böhlke 1966); the genus is found in all oceans. Six species of Monognathus Bertin have been described, based on few specimens; the genus has been recorded from the Pacific and eastern Atlantic. Castle and Raju (1975) described a peculiar saccopharyngoid larva that cannot be identified with any known adult.

References: Schmidt (1909), Bertin (1938), Orton (1963), Böhlke (1966), Raju (1974a), Castle and Raju (1975).

\section{Moringuidae (Figs. 10-11)}

Body moderately deep; gut two-thirds to three-fourths standard length, a thickened arch just anterior to vent with one or a few large expanded melanophores; dorsal fin beginning near level of vent; ventral pigment confined to a single melanophore on the anterior ventral surface of gut (Neoconger) and one or a few expanded melanophores on the dorsal surface of the intestinal thickening (Neoconger and Moringua); lateral pigment either as a few large, expanded melanophores alternately on either side of the body along the midlateral line (Moringua), or as a single melanophore near tail (Neoconger); maximum size 60-70 mm.

Two genera of moringuids are known, Moringua Gray and Neoconger Girard.

Larvae of Moringua (Fig. 10) have several large midlateral melanophores arranged alternately on either side of the body. Moringua is found in the Indo-Pacific and western Atlantic. The western Atlantic species is M. edwardsi (Jordan and Bollman) (113-122). Moringua edwardsi shows sexual dimorphism in the number of vertebrae (Castle and Böhlke 1976), and this may be true of other species of the genus.

Larvae of Neoconger (Fig. 11) have only one lateral melanophore near the tail. Neoconger occurs in the western Atlantic, eastern Pacific, and Australia. The western Atlantic species is N. mucronatus Girard and the eastern Pacific form is $N$. vermiformis Gilbert. The Australian species, $N$. tuberculatus (Castle), is based on two larvae found near Sydney, but adults have not been collected. Total myomeres and vertebrae in all forms range from about 96 to 110; the counts for the three species overlap broadly. An unidentified leptocephalus treated later in this report (Unidentified I) could be confused with Neoconger. The differences are given in the account of that form.

References: Castle (1965d), Eldred (1967c, 1968a), Smith and Castle (1972). 
A
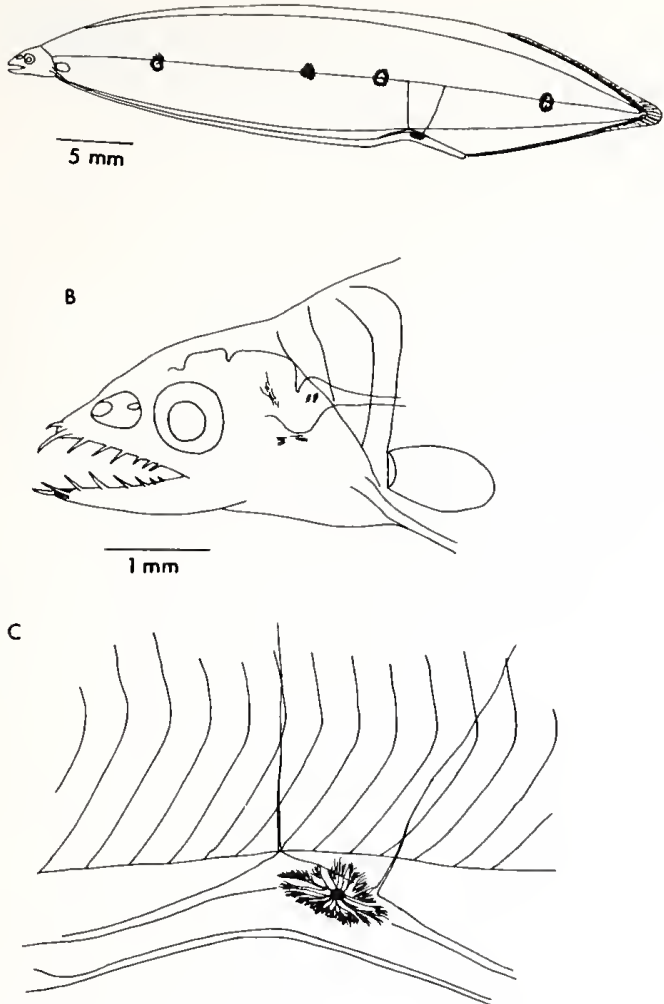

$1 \mathrm{~mm}$

Figure 10.-Moringuidae: Moringua edwardsi (Jordan and Bollman), $43 \mathrm{~mm}$ SL, MBI 179. A. Whole view. B. Head. C. Anal region.
A
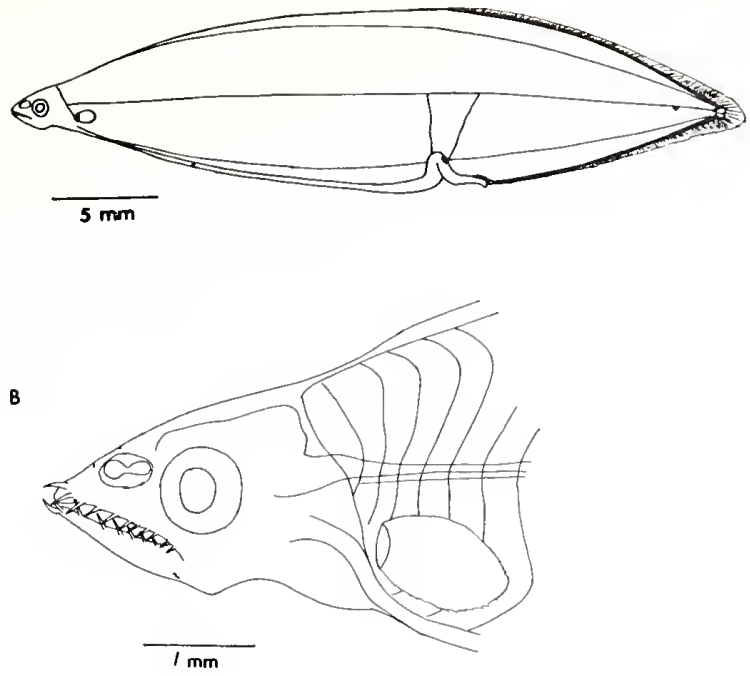

C

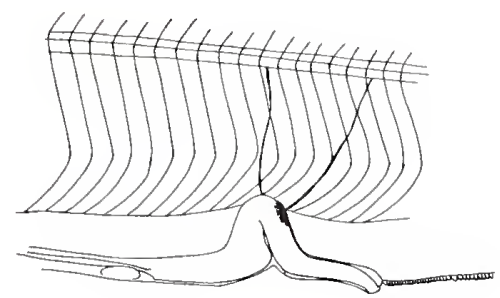

$1 \mathrm{~mm}$

Figure 11.-Moringuidae: Neoconger mucronatus Girard, $33 \mathrm{~mm}$ SL, MBI 83. A. Whole view. B. Head. C. Anal region.

Nettastomatidae (Figs. 12-14)

Body deep to elongate; tail pointed; gut usually less than one-half standard length with two thickenings (except Facciolella); dorsal fin long, generally beginning shortly behind head; head moderate to elongate; ventral pigment variable; lateral pigment variable; maximum size at least $200 \mathrm{~mm}$.

A

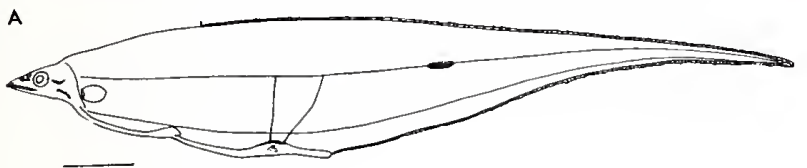

$1 \mathrm{~mm}$

B

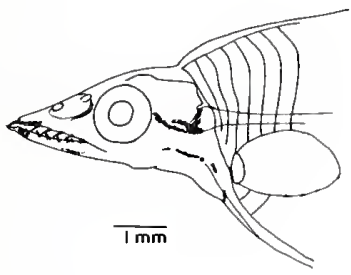

C

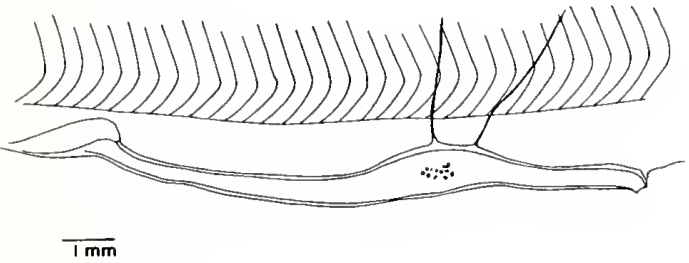

Figure 12.-Nettastomatiảa: NettastomaMetopomycter group, $51 \mathrm{~mm}$ SL, MBI 214.

A. Whole view. B. Head. C. Anal region. 


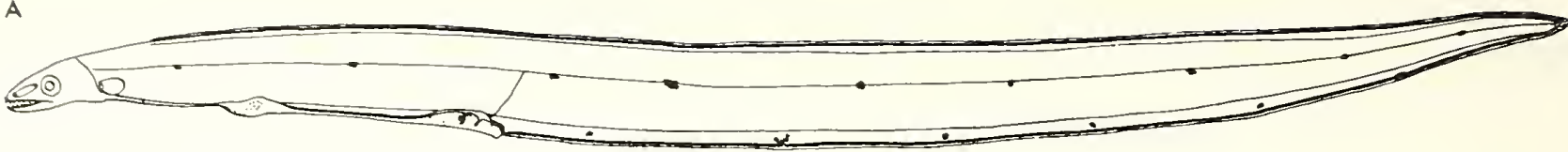

$5 \mathrm{~mm}$

B

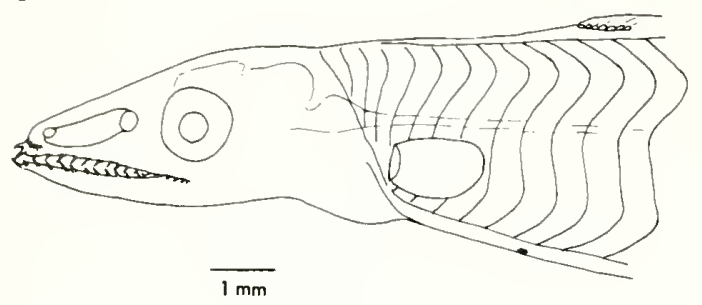

C

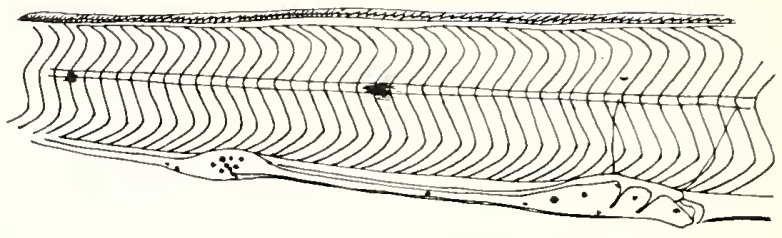

$\overline{1 \mathrm{~mm}}$

D

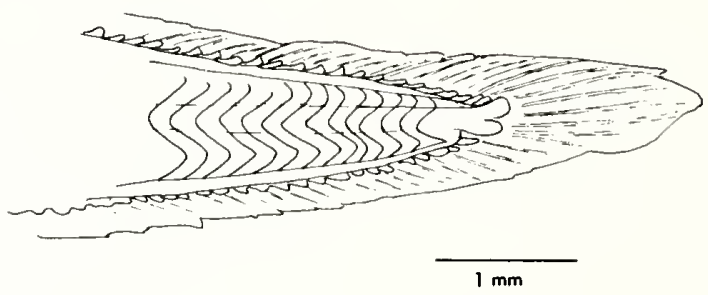

Figure 13.-Nettastomatidae: Hoplunnis macrura Ginsburg, $84 \mathrm{~mm}$ SL, MBI 202. A. Whole view. B. Head. C. Gut. D. Tail.

There are three basic types of nettastomatid larvae.

The larva of Nettastoma melanurum Rafinesque (190-207) is deep-bodied anteriorly, tapering sharply toward the tail, with a single deep-lying, horizontally elongate pigment spot on the notochord behind the vent. The intestinal thickenings are often reduced. Larvae of Nettastoma are found in the Mediterranean, the eastern and western Atlantic, and the Indo-Pacific. Similar larvae are known which have shallower bodies and different counts; these presumably belong to eels closely related to Nettastoma (Fig. 12).

Larvae of Hoplunnis Kaup have elongate, uniformly shallow bodies and well-developed intestinal thickenings (Fig. 13). Saurenchelys Peters may have a similar larva, but this has not yet been confirmed. Larvae of this type are found in all oceans.

Larvae of Facciolella Whitley lack the well-defined intestinal thickenings characteristic of the Nettastoma and Hoplunnis groups (Fig. 14). The body is elongate and uniformly shallow and the head is relatively long. In younger specimens the rostral cartilage has an anterior projection that extends noticeably beyond the end of the lower jaw and bears the premaxillary teeth (Fig. 14D). In more advanced individuals the fleshy part of the snout grows forward and envelops the rostral projection (Fig. 14C). This larva was originally described as Saurenchelys cancrivora Peters (Grassi 1913; Lea 1913; Sanzo 1938), a species that was long confused with Facciolella physonema (Facciolà). Larvae of Facciolella occur on both sides of the Atlantic, including the Mediterranean, and the Indo-Pacific.

References: Grassi (1913), D’Ancona (1931), Sanzo (1938), Spartà (1942), Castle (1964c), Keller (1976).

Cyemidae (Figs. 15-16)

Body very short and deep; gut about two-thirds standard length with three or four arches in the posterior half, each with a melanophore at its peak; snout long and straight; several melanophores scattered over lateral body surface; dorsal fin origin near level of vent; maximum size 60-70 mm.

The larva of Cyema atrum Gunther (Fig. 15), the only species so far recognized in the family, is one of the most distinctive and easily recognized leptocephali. In addition to its peculiar body form, it has the fewest myomeres of any known eel larvae, around 80 . The bathypelagic adult is found in all oceans. 
A

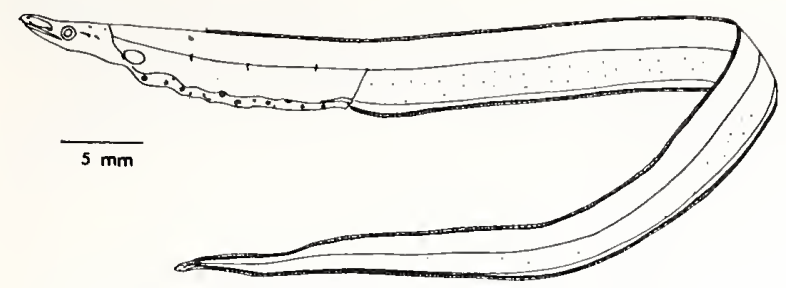

B

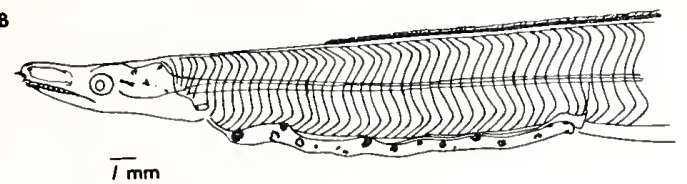

C

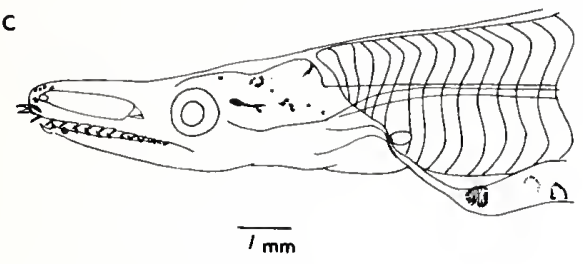

D

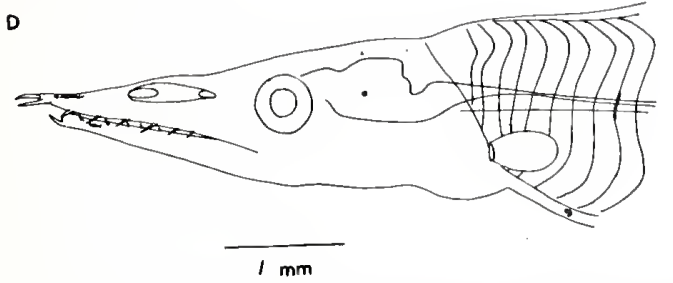

A

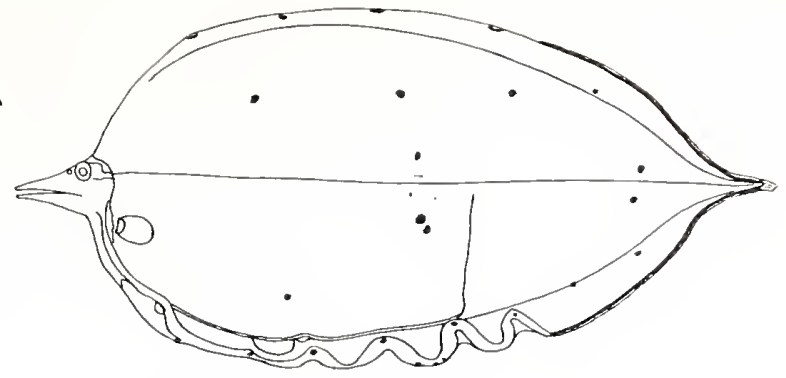

$5 \mathrm{~mm}$

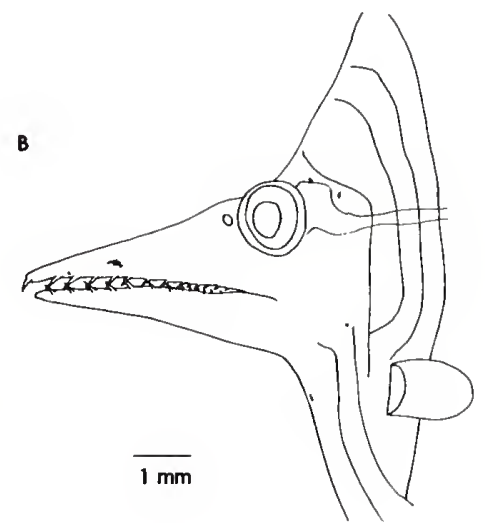

Figure 15.-Cyemidae: Cyema atrum Günther, $42 \mathrm{~mm}$ SL, GS 84 . A. Whole view. B. Head.

Figure 14.-Nettastomatidae: Facciolella sp. A. Whole view, 87 mm SL, MBI 200. B. Anterior body, same. C. Head, same. D. Head, $38 \mathrm{~mm}$ SL, MBI 195.

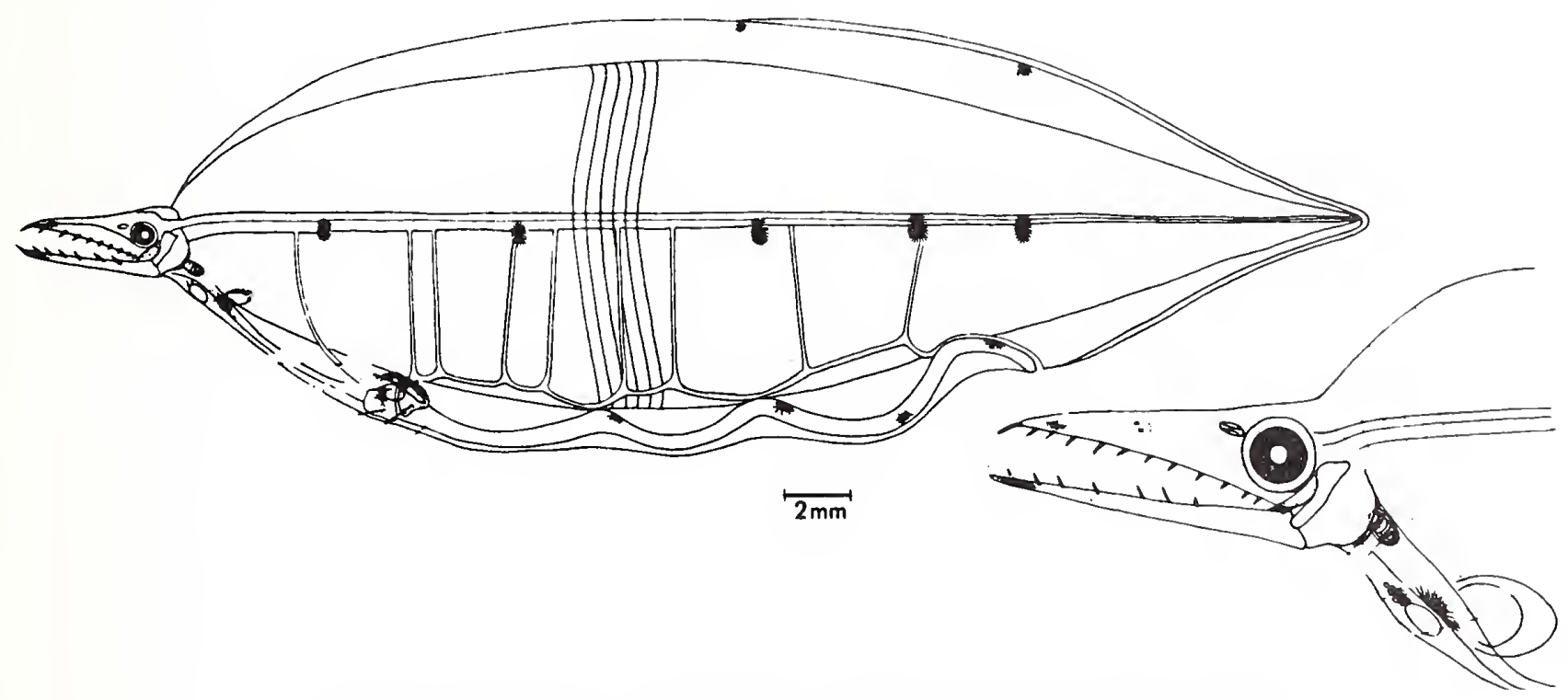

Figure 16.-Cyemidae (?): Leptocephalus holti Schmidt, $40 \mathrm{~mm}$ SL, from Raju (1974a). 
Leptocephalus holti Schmidt (Fig. 16) resembles Cyema, differing mainly in having a shallower body and lateral pigment restricted to the midline. The type was collected in the eastern North Atlantic, but a similar specimen was taken in the southwestern Pacific (Raju 1974a). The resemblance of this larva to Cyema suggests that they may be related.

References: Schmidt (1909), Roule and Bertin (1929), Bertin (1937), Raju (1974a).

\section{Ophichthidae (Figs. 17-21)}

Body moderately elongate; tail moderate to blunt, caudal fin sometimes absent; gut about one-half to two-thirds standard length, with a variety of thickenings and/or arches; snout generally moderately elongate; ventral pigment tends to be concentrated on intestinal thickenings and arches; lateral pigment variable; maximum size $80-180 \mathrm{~mm}$.

This is one of the largest and most variable of the eel families, and its larvae are commonly collected. Ophichthid larvae can usually be recognized by the arches or swellings in the gut, but a few forms are known in which these intestinal modifications are inconspicuous.

In the larvae of the Myrophinae, the third intestinal thickening is the largest, and the kidney is confined to the posterior end of the gut. The larva of Myrophis punctatus Lütken (138-148, Fig. 17), the common spotted worm eel of the western Atlantic, has three swellings anteriorly, a less conspicuous swelling near the vent associated with the kidney, and an even smaller one between the third swelling and the vent. The larva of Ahlia egmontis (Jordan) (157-167, Fig. 18) is similar but has a more posterior dorsal fin origin and different lateral pigment, in the form of short diagonal lines on the myosepta immediately below the midlateral line. In addition there are a few subcutaneous pigment spots laterally behind the vent.

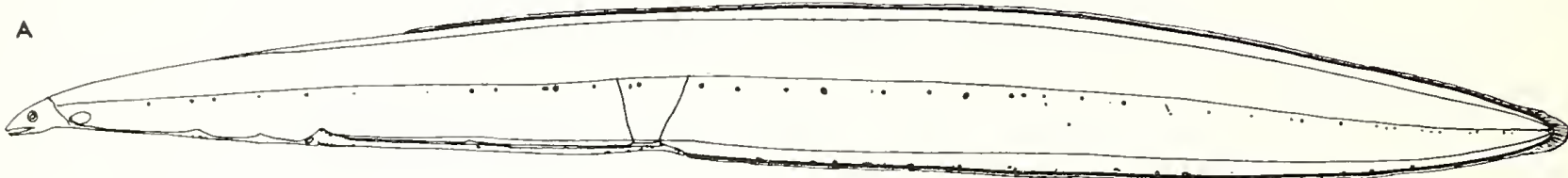

$5 \mathrm{~mm}$

B

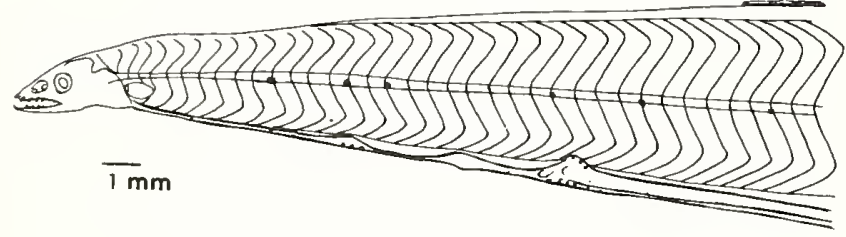

D

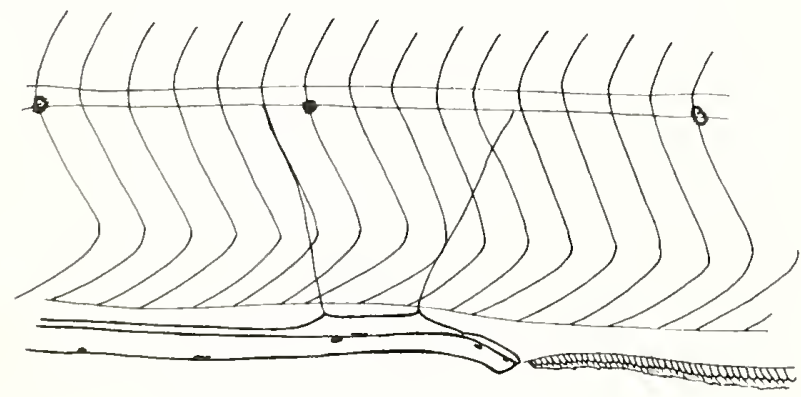

$C$

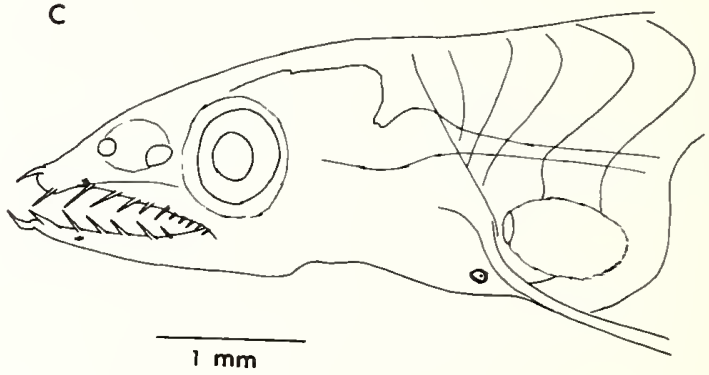

E

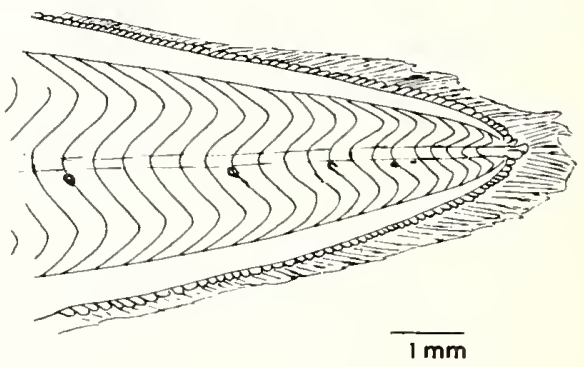

$1 \mathrm{~mm}$ Figure 17.-Ophichthidae: Myrophis punctatus Lütken, $78 \mathrm{~mm}$ SL, MBI 198.
E. Tail.

A. Whole view. B. Anterior body. C. Head. D. Anal region. 
A

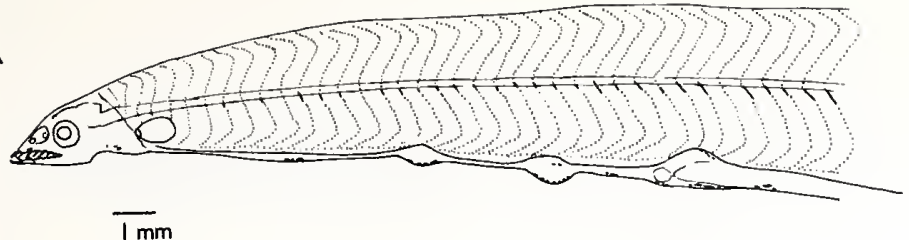

B

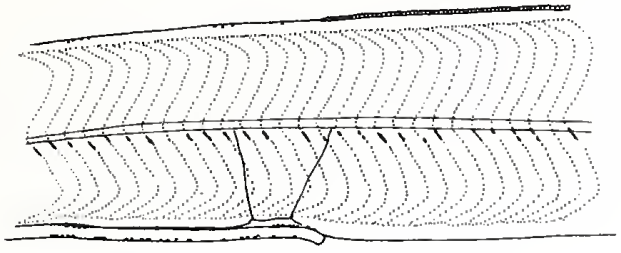

Figure 18.-Ophichthidae: Ahlia egmontis (Jordan), $82 \mathrm{~mm}$ SL, MBI 36. A. Anterior body. B. Anal region.

$\overline{T m}$

A

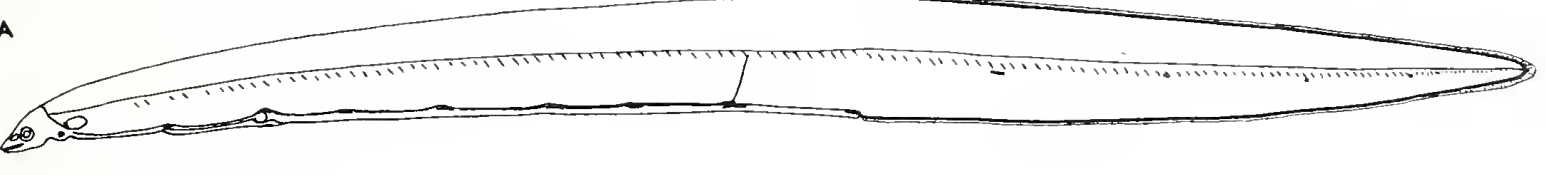

$5 \mathrm{~mm}$

B

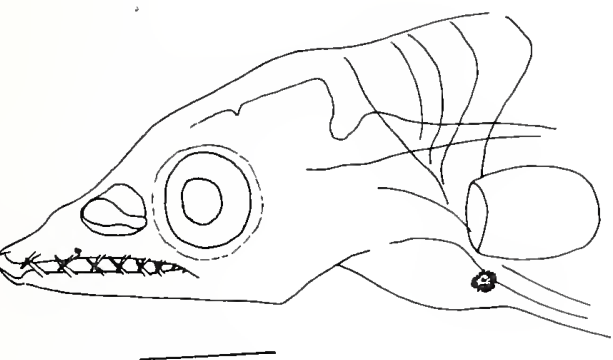

C

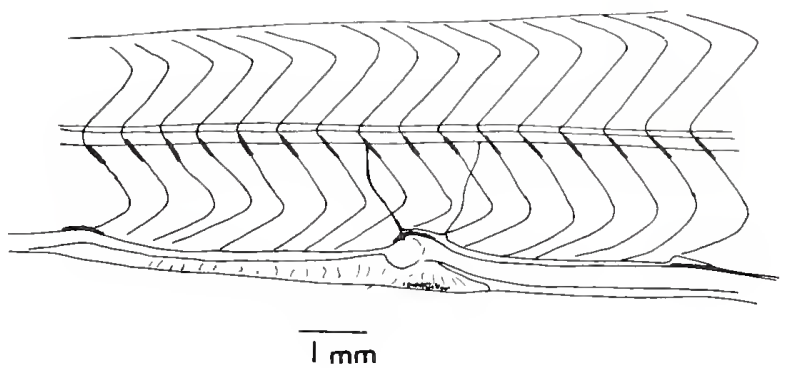

$1 \mathrm{~mm}$

D

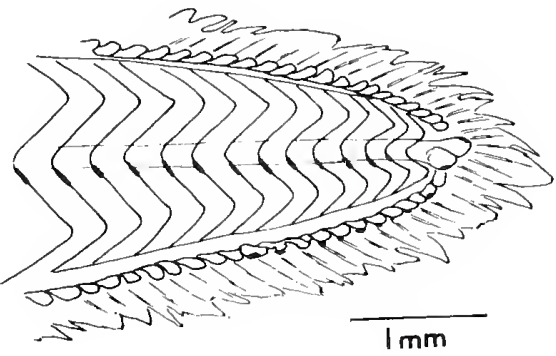

Figure 19.-Ophichthidae: Ophichthus sp., $77 \mathrm{~mm}$ SL, MBI 345. A. Whole view. B. Head. C. Anterior gut showing first two intestinal swellings with liver and gall bladder. D. Tail. 


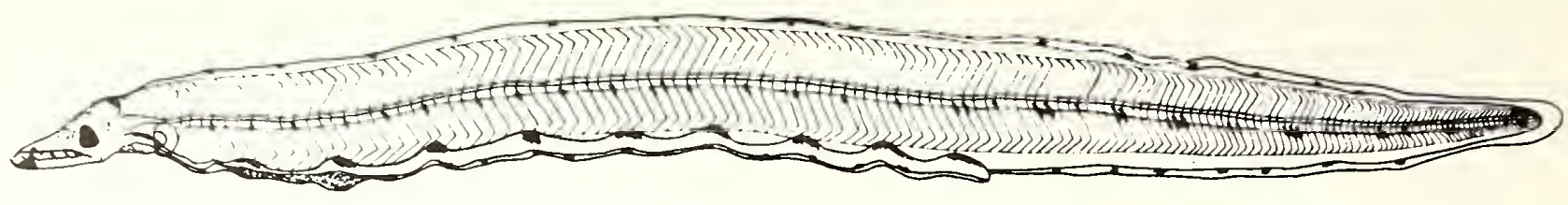

Figure 20.-Ophichthidae: Pisodonophis cruentifer Goode and Bean, $32 \mathrm{~mm}$ SL, from Richardson (1974).

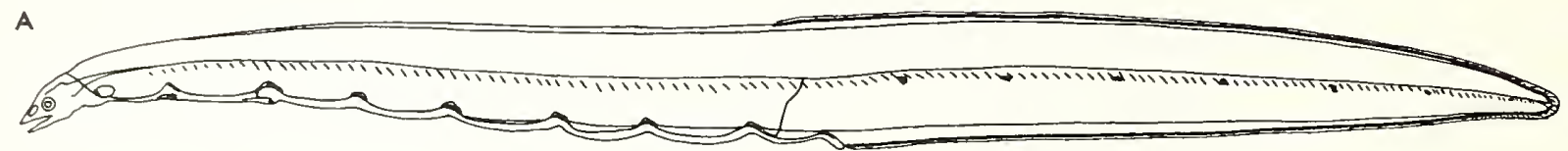

$5 \mathrm{~mm}$

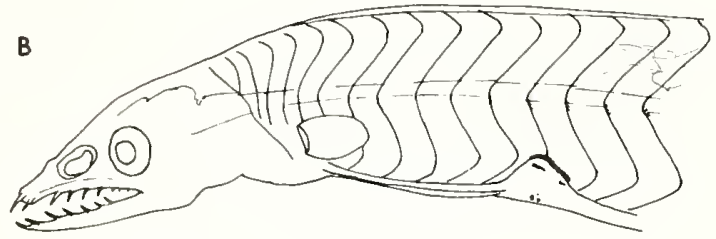

$1 \mathrm{~mm}$
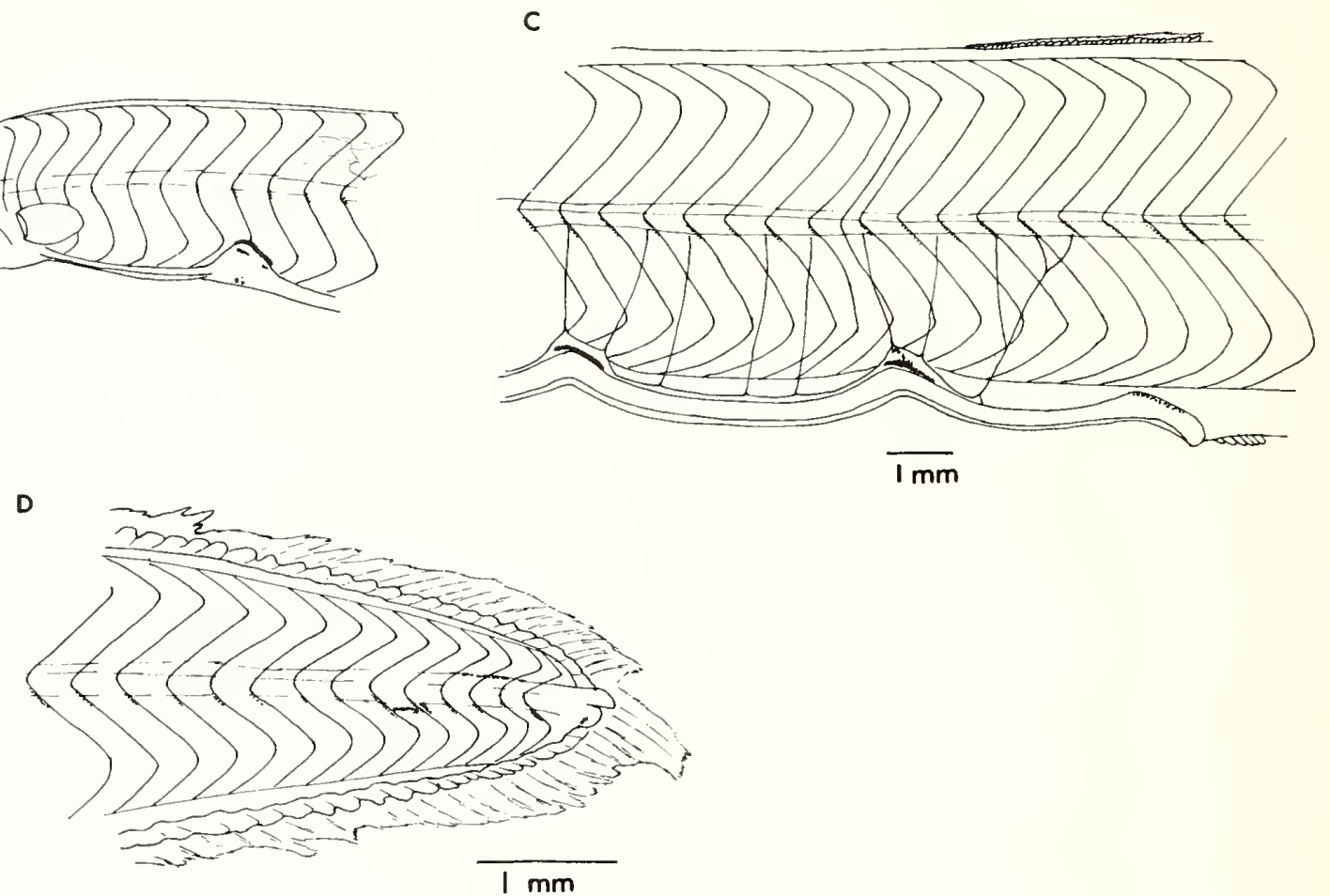

Figure 21.-Ophichthidae: unidentified, $72 \mathrm{~mm} \mathrm{SL}, \mathrm{MBI} 338$. A. Whole view. B. Head. C. Anal region. D. Tail.

In larvae of the Ophichthinae, the second intestinal swelling is the largest, and the kidney extends some distance along the gut. Larvae of Ophichthus Ahl (Fig. 19) and Dalophis Rafinesque have the intestinal swellings reduced. Pigment varies, but in most cases the myosepta immediately below the midlateral line are outlined by short diagonal lines, as in Ahlia Jordan and Davis. Pisodonophis cruentifer Goode and Bean (146-152) (Fig. 20), from the east coast of North America, has nine intestinal arches and pigment on the dorsal and ventral midlines in addition to midlaterally. An unidentified ophichthine larva is shown in Figure 21. There are eight pronounced intestinal arches, each capped by black pigment.

Several other ophichthid larvae have been identified, particularly from the Mediterranean, but much work remains to be done. Blache (1977) dealt extensively with ophichthid larvae. At least 40 species of ophichthid eels exist in the western Atlantic. Larvae of Myrophis punctatus, Ahlia egmontis, Pisodonophis cruentifer, and Pseudomyrophis nimius Böhlke have been identified.

References: D’Acona (1931), Spartà (1937, 1938a, 1939a, 1940), Castle (1965c), Eldred (1966), Dean (1968), Richardson (1974), Blache (1977), Fahay and Obenchain (in press). 
Body moderately deep; gut a simple, straight tube about two-thirds standard length; dorsal fin origin slightly anterior to level of vent; head moderate with rather short snout; melanophores absent; maximum size $80 \mathrm{~mm}$.

The Anguillidae contains 15 species, all in the genus Anguilla Shaw and all catadromous. Two species are found in the Atlantic and 13 in the Indo-Pacific. It is a closely knit group, species differing mainly meristically. Larvae of Anguilla are about the only leptocephali that completely lack melanophores. Castle (1965b) reported that the larvae of the muraenid genus Anarchias, at least the Australasian species, are also without melanophores, but these can be separated from Anguilla by the reduced fins and the shorter gut.

Larvae of both Anguilla anguilla (Linnaeus) (111-119) and $A$. rostrata (Lesueur) (104-111) are found in the western Atlantic, although $A$. rostrata predominates near the American coast.

References: Schmidt (1925), Jespersen (1942), Castle (1963), Smith (1968), Eldred (1968c).

A

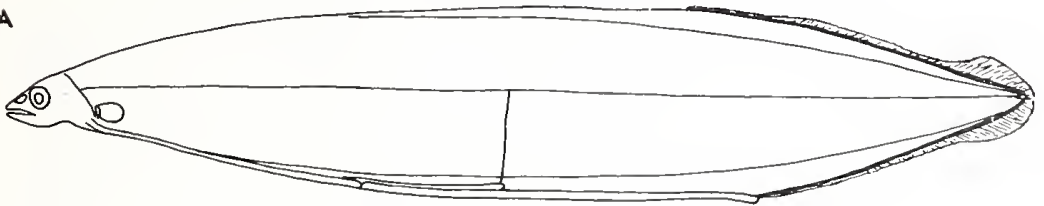

$5 \mathrm{~mm}$
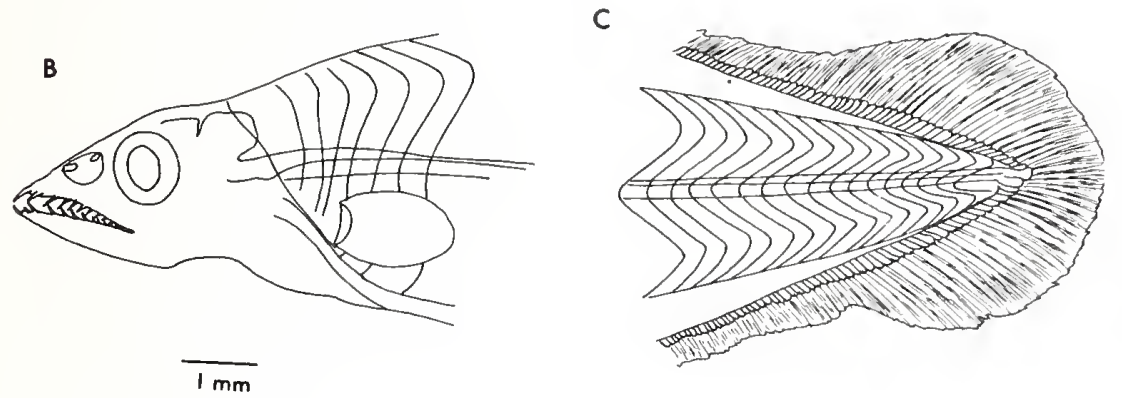

Figure 22.-Anguillidae: Anguilla rostrata (Lesueur), $48 \mathrm{~mm}$ SL, MBI 36. A. Whole view. B. Head. C. Tail.

Derichthyidae: Nessorhamphus (Fig. 23)

Deepest point of body somewhat behind midlength; tail sharp; gut simple and long, about nine-tenths standard length; dorsal fin origin slightly behind midlength; snout rather long; no ventral pigment; lateral pigment limited to a few small melanophores near tip of tail; last vertical blood vessel around myomere 75-80; preanal myomeres 118-121 in $N$. ingolfianus; maximum size $70-80 \mathrm{~mm}$.

Larvae of Nessorhamphus, Derichthys, and the Serrivomeridae are similar enough to cause confusion (Figs. 23-25). They all have a simple gut, all lack intestinal pigment, and all have inconspicuous lateral pigment. The best way to separate them is by the position of the last vertical blood vessel.
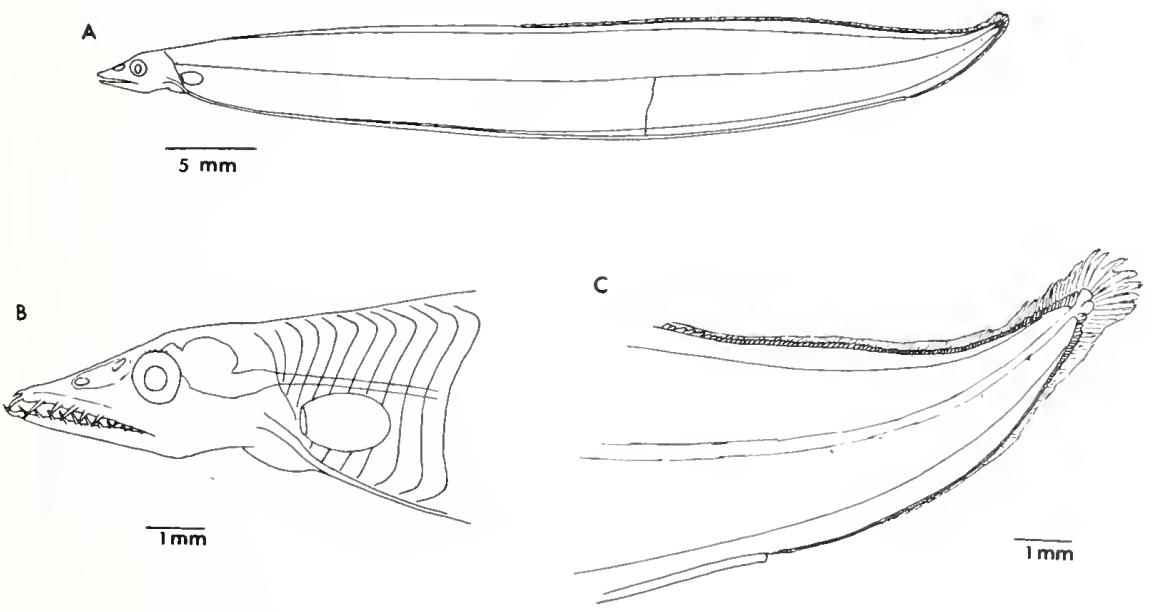

Figure 23.-Derichthyidae: Nessorhamphus ingolfianus (Schmidt), $51 \mathrm{~mm}$ SL, P 1111. A. Whole view. B. Head. C. Tail. 
Nessorhamphus Schmidt was formerly placed in its own family, the Nessorhamphidae, but Robins and Robins (1971) transferred it to the Derichthyidae. The two recognized species are circumtropical, but $N$. danae Schmidt (135-145) is an equatorial species, found within $5^{\circ}-10^{\circ}$ of the Equator, whereas $N$. ingolfianus (Schmidt) (149-159) is found from about $10^{\circ}$ to $30^{\circ}$ both north and south of the Equator.

References: Schmidt (1930, 1931), Beebe (1935).

\section{Derichthyidae: Derichthys (Fig. 24)}

Gut simple, about three-fourths standard length; dorsal fin origin at about midbody; snout rather short with a rather flat or slightly concave dorsal profile; nasal organ moderately large; pigment restricted to a few small melanophores on myosepta midlaterally in postanal region; last vertical blood vessel at myomere 59-63; preanal myomeres 76-83; maximum size $50-60 \mathrm{~mm}$.

Superficially, the larva of Derichthys serpentinus Gill (126-134), the only species in the genus, resembles Anguilla. In fact, it was first described under the name Leptocephalus anguilloides Schmidt. Aside from its more numerous myomeres, however, it differs from larval Anguilla by having small melanophores. Other leptocephali that could be confused with Derichthys are the serrivomerids and Nessorhamphus. Derichthys serpentinus is cosmopolitan.

Reference: Castle (1970b).
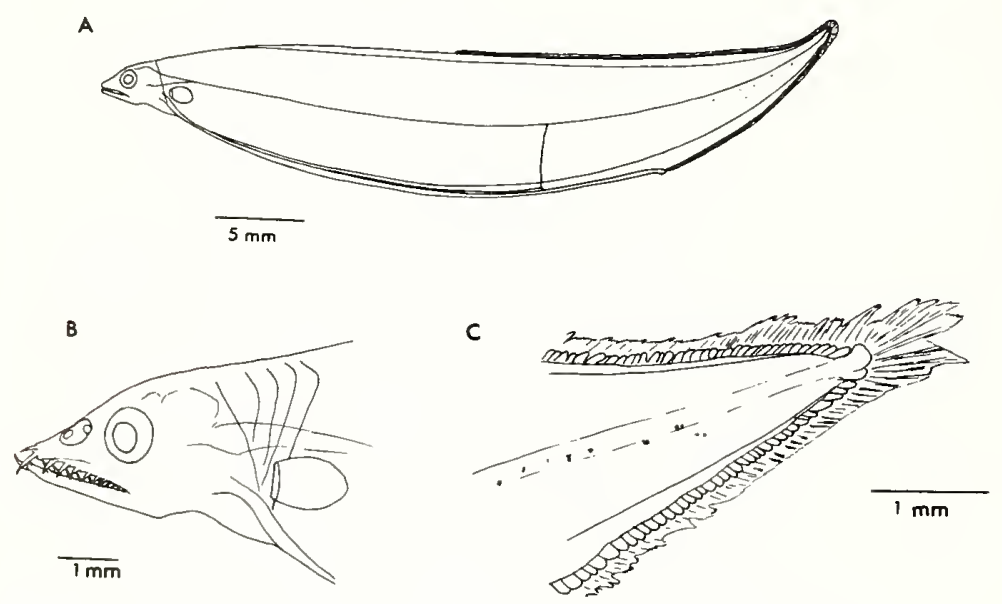

Figure 24.-Derichthyidae: Derichthys serpentinus Gill, $42 \mathrm{~mm} \mathrm{SL}, \mathrm{P} 1111$. A. Whole view. B. Head. C. Tail.

\section{Serrivomeridae (Fig. 25)}

Tail sharp; gut simple, about two-thirds to three-fourths standard length; dorsal fin origin somewhat in front of level of vent; head moderate with sharp snout and concave dorsal profile; nasal organ small and close to eye; no intestinal pigment; lateral pigment absent or limited to small melanophores on myosepta along midline, sometimes restricted to postanal region; last vertical blood vessel at myomere 30-37; preanal myomeres ca. 89-125; maximum size $60 \mathrm{~mm}$.
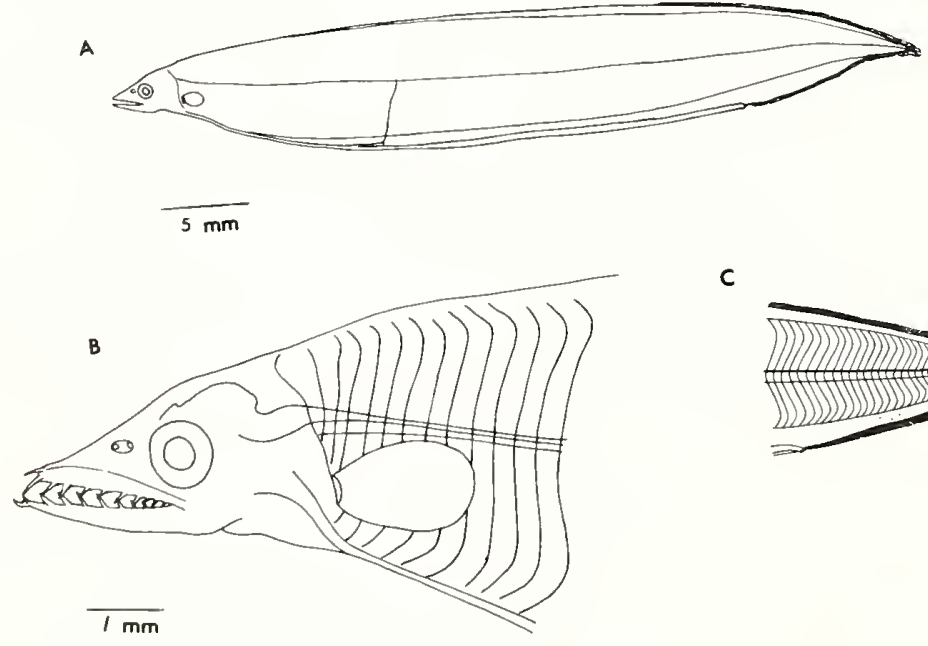

C

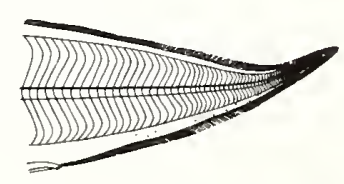

Figure 25.-Serrivomeridae. A. Whole view, $46 \mathrm{~mm} \mathrm{SL}$, CI 190. B. Head, same. C. Tail, $45 \mathrm{~mm}$ SL, from Bauchot (1959). 
The serrivomerids are common midwater eels. Numerous species and at least three genera have been described, but the family needs critical study to confirm the validity of these nominal taxa. According to the literature, larvae of the following western Atlantic species have been described: Platuronides acutus Parr (153-158), $P$. danae Roule and Bertin (165-170), Serrivomer beani Gill and Ryder (154-165), S. brevidentatus Roule and Bertin (155-165), and S. parabeani Bertin (156-163).

References: Bauchot (1959), Beebe and Crane (1936, 1937a).

Muraenidae (Figs. 26-30)

Body moderate to moderately deep; tail broadly rounded; gut simple, about one-half to three-fourths standard length (longer in Channomuraena); dorsal fin variable, originating anywhere from shortly behind head to near tip of tail; head with short, blunt snout; posterior nostril near level of upper margin of eye; pectoral fin greatly reduced; pigment

A

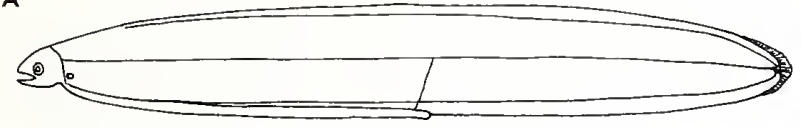

$5 \mathrm{~mm}$

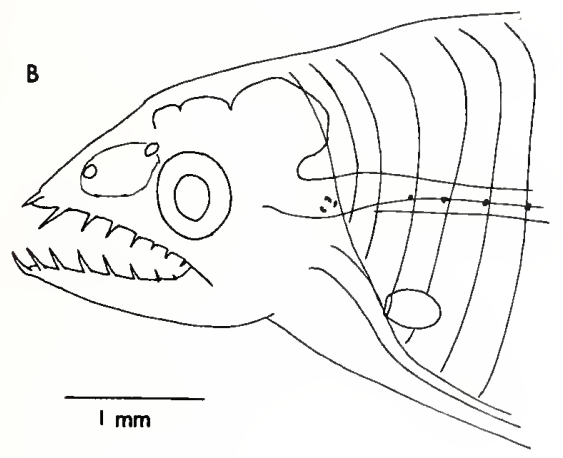

C

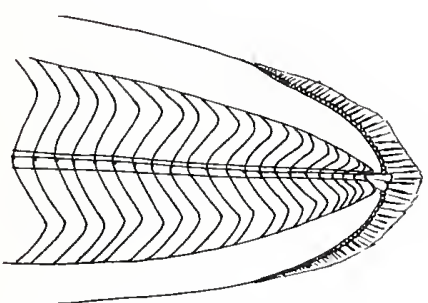

$\overline{I m m}$
Figure 26.-Muraenidae:Anarchias yoshiae Kanazawa, $40 \mathrm{~mm}$ SL, MBI 30. A. Whole view. B. Head. C. Tail.
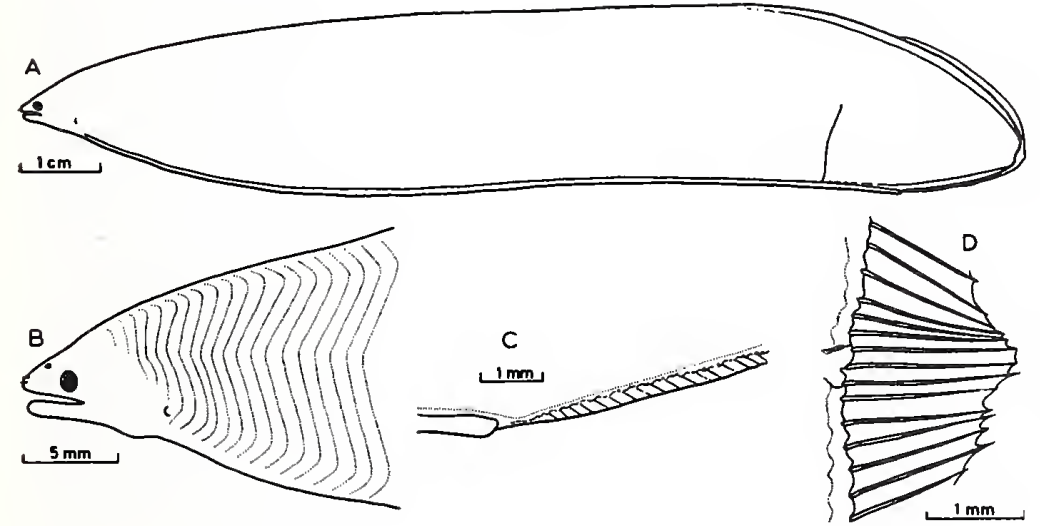

Figure 27.--Muraenidae: Channomuraena vittata (Richardson), $124 \mathrm{~mm}$ TL (metamorphosing), from Castle (1970a). A. Whole view. B. Head. C. Anal region. D. Tail. 


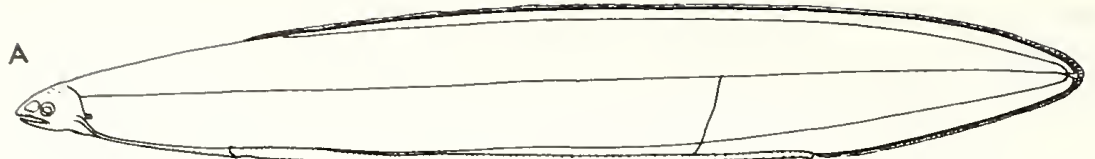

$5 \mathrm{~mm}$
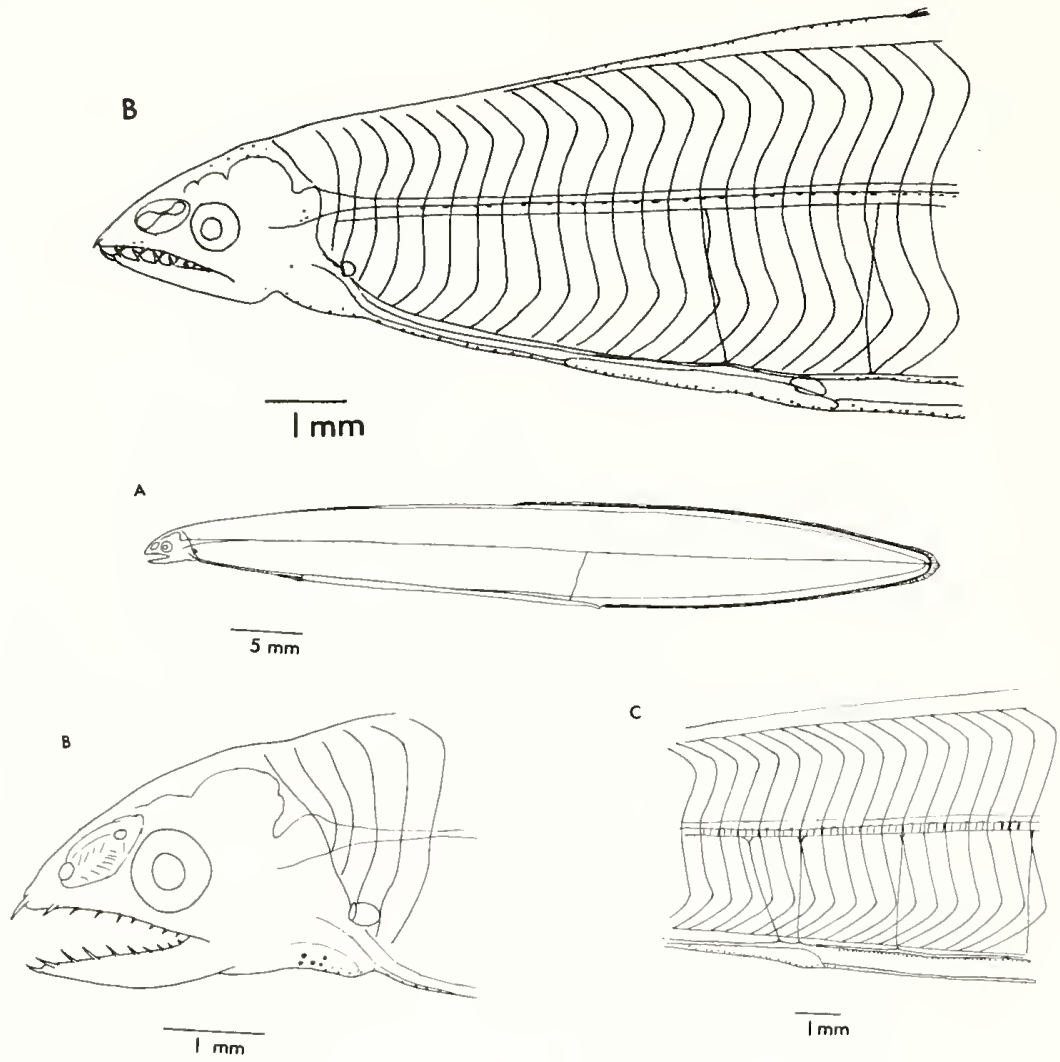

$\overline{1 \mathrm{~mm}}$
Figure 28.-Muraenidae: Gymnothorax nigromarginatus (Girard), $44 \mathrm{~mm} \mathrm{SL}$, MBI 345. A. Whole view. B. Head and anterior body.

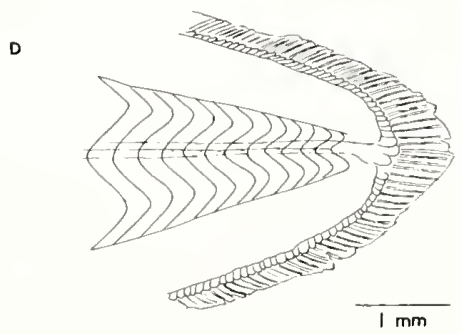

Figure 29.-Muraenidae: Gymnothorax moringa (Cuvier), $56 \mathrm{~mm}$ SL, MBI 36 . A. Whole view. B. Head. C. Gastric region. D. Tail.

variable, may consist of small melanophores along gut, on head, or internally on underside of spinal cord, but never on lateral body surface; maximum size $60-70 \mathrm{~mm}$.

The greatly reduced pectoral fin of muraenid larvae is unique among eel larvae. Other eels have lost the pectoral fin in the adult, but only the morays show this reduction in the larval stage. The high posterior nostril, the short, blunt snout, and the broadly rounded tail further characterize muraenid larvae.

This is one of the largest and most important of the eel families, and one of the most homogeneous. It does not show the great variation in larval and adult morphology characteristic of the two other large eel families, the Ophichthidae and Congridae.

Larvae of Anarchias Jordan and Starks and Uropterygius Rüppell have the dorsal and anal fins confined to the posterior extremity of the body (Fig. 26). These are the only leptocephali in which the anal fin origin is widely separated from the vent. Uropterygius has melanophores on the top of the head, around the pectoral fin, internally on the base of the brain, and on the underside of the gut. Anarchias (Fig. 26) has only a few internal melanophores near the base of the brain. Blache (1971) reported inconspicuous intestinal pigment on eastern Atlantic Anarchias, but this is not found in larvae from the western Atlantic or Australasian regions. Castle (1965b) reported no melanophores at all in his Austral- 


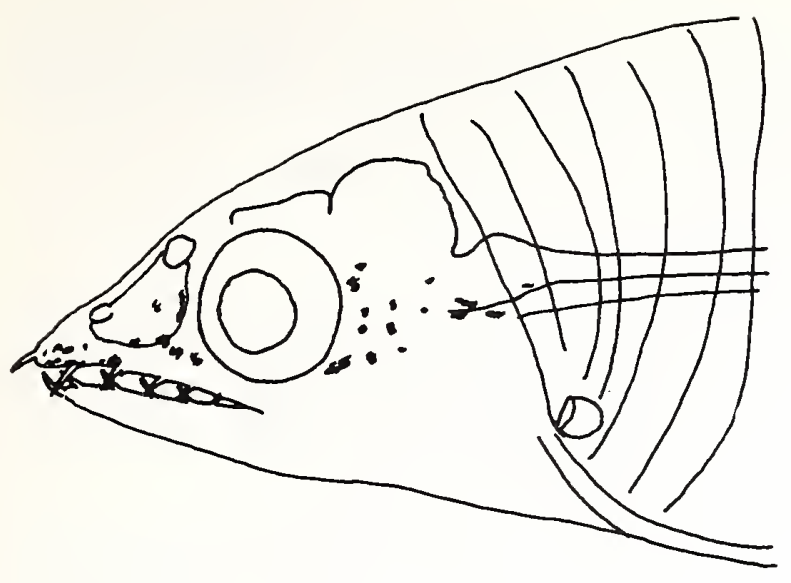

Figure 30.-Muraenidae: Muraena miliaris (Kaup) (?), $51 \mathrm{~mm}$, MBI 340 .

\section{$\mathrm{I} \mathrm{mm}$}

asian specimens. One species of each genus occurs in the western Atlantic, Anarchias yoshiae Kanazawa (107-114) and Uropterygius juliae (Tommasi) (118-123).

Channomuraena vittata (Richardson) (ca. 149, Fig. 27) from the Atlantic also has the vertical fins restricted to the posterior end of the body, but its gut reaches the anal fin origin.

The remaining muraenid larvae have the dorsal and anal fin origins considerably farther forward. With a few exceptions, they are difficult to identify, due largely to the overlap in vertebral numbers of many species.

The most common group of muraenid larvae belongs to the Gymnothorax Bloch complex (Figs. 28-29). The dorsal fin begins over or ahead of the vent, cephalic pigment consists of small, discrete melanophores variably placed, and intestinal pigment is present. Many species are known, but few larvae have been identified with certainty. They differ meristically and by subtle variations in cephalic and ventral pigment.

In the western Atlantic, the larva of Gymnothorax nigromarginatus (Girard) (Fig. 28) has a relatively long gut (about three-fourths standard length) and the dorsal origin is well in front of the vent. Melanophores are present on top of the head and along both the top and bottom of the intestine. Gymnothorax nigromarginatus (137-145), G. saxicola Jordan and Davis (135-144), and G. ocellatus Aggassiz (142-150) are all closely related and their larvae are probably similar. Adults of three additional species of this group, i.e., those with serrated teeth, have been found in the western North Atlantic and have vertebral counts of 132-137, 162-167, and 163-174.

The remaining Gymnothorax-type larvae in the western Atlantic have a shorter gut (slightly over one-half standard length) and a dorsal origin over or slightly ahead of the vent. Several species exist but, with one probable exception, overlapping vertebral-myomere numbers preclude positive identification. The exception is G. moringa (Cuvier) (134142, Fig. 29), identified by Eldred (1970). The adult is the most abundant western Atlantic species of Gymnothorax (aside from the nigromarginatus complex), and the relative abundance of the larva combined with the close agreement in the number of myomeres and vertebrae make this identification likely to be correct, although $G$. funebris Ranzani (139-145) and G. polygonius Poey (134-140) overlap broadly. The remaining species is G. vicinus Castelnau (129-136). Two species of Enchelycore Kaup, E. nigricans (Bonnaterre) (141-147) and E. carynhroa Böhlke and Böhlke (131-140), are found in the western Atlantic. If these also have a Gymnothorax-type larva, the problem of larval identification would be complicated even further. Enchelycore, particularly nigricans, is common enough that its larva should have been collected. The only larvae known that fit the vertebral counts of the two species of Enchelycore are of the Gymnothorax type.

Five species of Muraena Linnaeus occur in the western Atlantic: M. miliaris (Kaup) (118-126), M. pavonina Richardson (125-128), M. punctata Castelnau (128-132), M. retifera Goode and Bean (128-135), and M. robusta Osorio (153-156). Muraena miliaris is the most common species, and it is possible that the larva described by Eldred (1969a) as Rabula acuta is really this species. The myomere count (120-121) is too low for $R$. acuta but agrees with M. miliaris. Muraena is a widespread genus, and the larvae should be found in all oceans. The stripe of deep pigment on the head (Fig. 30) is the most conspicuous character.

Rabula acuta (Parr) (123-129) differs from all other western Atlantic morays in having the dorsal fin origin between the vent and the tip of the tail. Since the dorsal fin origin never seems to move backward at metamorphosis, the larvae of this species should have a relatively posterior dorsal fin origin, around the 74th-76th myomere. This is much farther back than in any species outside the Anarchias-Uropterygius-Channomuraena group, and should enable the larvae to be recognized. The larva described by Keller (1976) as Type I fits these conditions and may well be the true $R$. acuta. This species is probably not congeneric with the Indo-Pacific species that have been placed in Rabula Jordan and Davis. 
Castle (1965b) tentatively identified three species of Echidna Forster. These larvae are relatively deep-bodied and lack ventral and lateral pigment. One species of Echidna occurs in the western Atlantic, E. catenata (Bloch) (114-119). The low number of myomeres should make the larva of this species easy to recognize, but no such larva is known.

The larva of Thyrsoidea macrura (Bleeker) has been identified by Nair (1947).

References: Nair (1947), Castle (1965b, 1970a), Eldred (1968b, 1968d, 1969a, 1969b, 1970), Blache (1971), Keller (1976).

\section{Nemichthyidae (Figs. 31-32)}

Body elongate, tail moderate or attenuated; gut long and simple; snout sharp, peglike with concave dorsal profile; nasal organ small; small melanophores along top of gut posterior to gastric region, and on bottom of gut anterior to this point; lateral pigment, when present, consisting of a few widely spaced spots below midlateral line; internal melanophores along top of spinal cord extending length of body; maximum size $300-400 \mathrm{~mm}$.

Two major types of nemichthyid larvae exist.

Larvae of Nemichthys Richardson (Fig. 31) are extremely elongate with an attenuated, filiform tail. Myomeres are extremely numerous, well over 300 , although they are difficult to count posteriorly. These larvae can reach $400 \mathrm{~mm}$ before metamorphosing. It has long seemed likely that more than one species of Nemichthys exist, as evidenced by Roule and Bertin's "Leptocephalus A" and "Leptocephalus B." Nielsen and Smith (in press) have recognized three species: Nemichthys scolopaceus Richardson, $N$. curvirostris (Stromman), and $N$. larseni Nielsen and Smith. Very small larvae of $N$. scolopaceus have two or three prominent pigment spots laterally below the midline (Fig. 31A). At this stage they can easily be confused with Avocettina (Fig. 32A). In Nemichthys these pigment spots are lower on the body than in
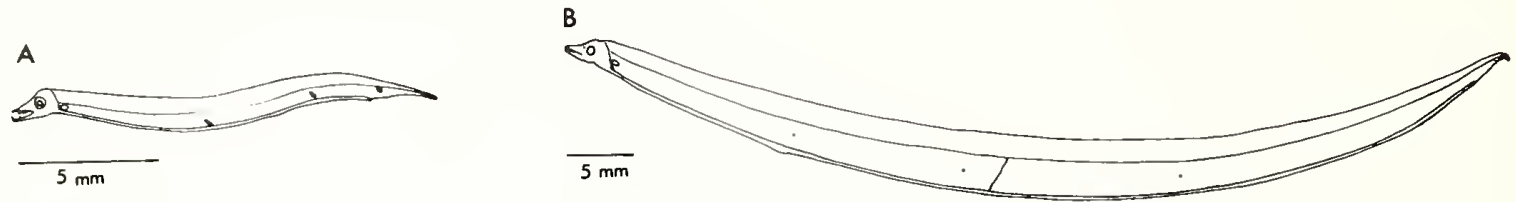

C

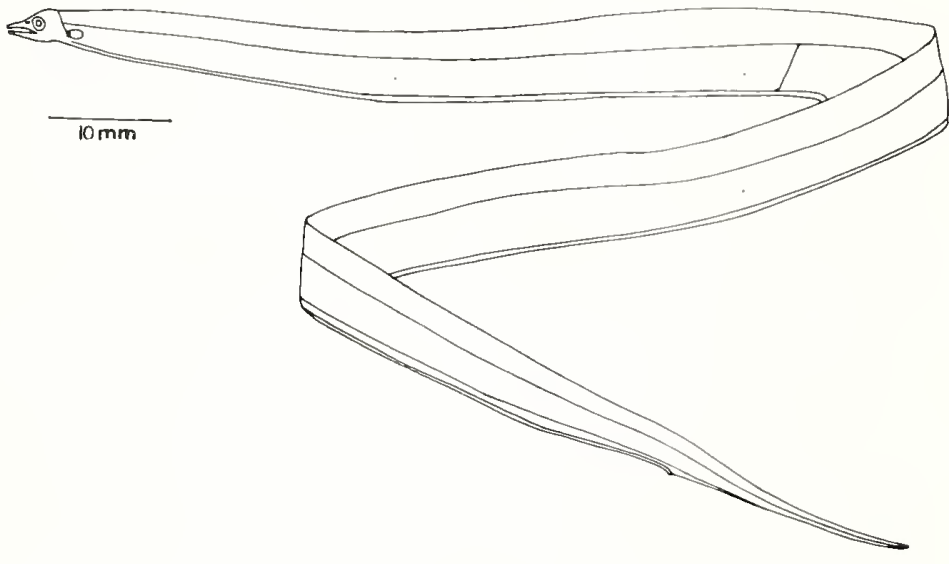

D

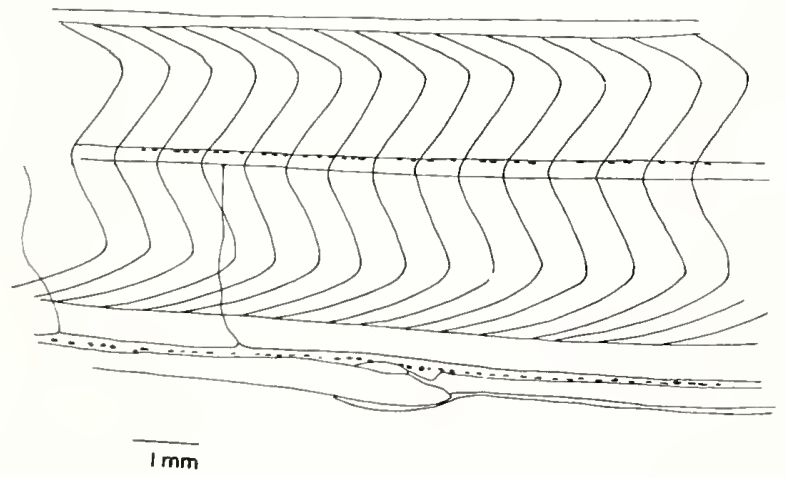

$\mathbf{F}$

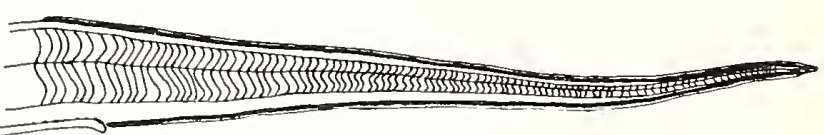

$T \mathrm{~mm}$

Figure 31.-Nemichthyidae: Nemichthys scolopaceus Richardson. A Whole view, $15 \mathrm{~mm}$ SL, adapted from Roule and Bertin (1929). B. Whole view, $72 \mathrm{~mm}$ SL, MBI 163. C. Whole view, $182 \mathrm{~m} \mathrm{~m} \mathrm{SL}, \mathrm{P} 1392$. D. Head. E. Gastric region. F. Tail. 
A

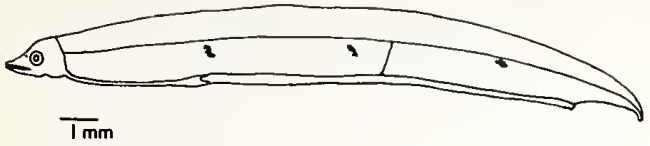

$\bar{T} \mathbf{m}$
B

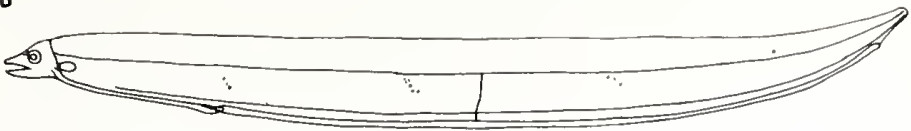

$5 \mathrm{~mm}$

C
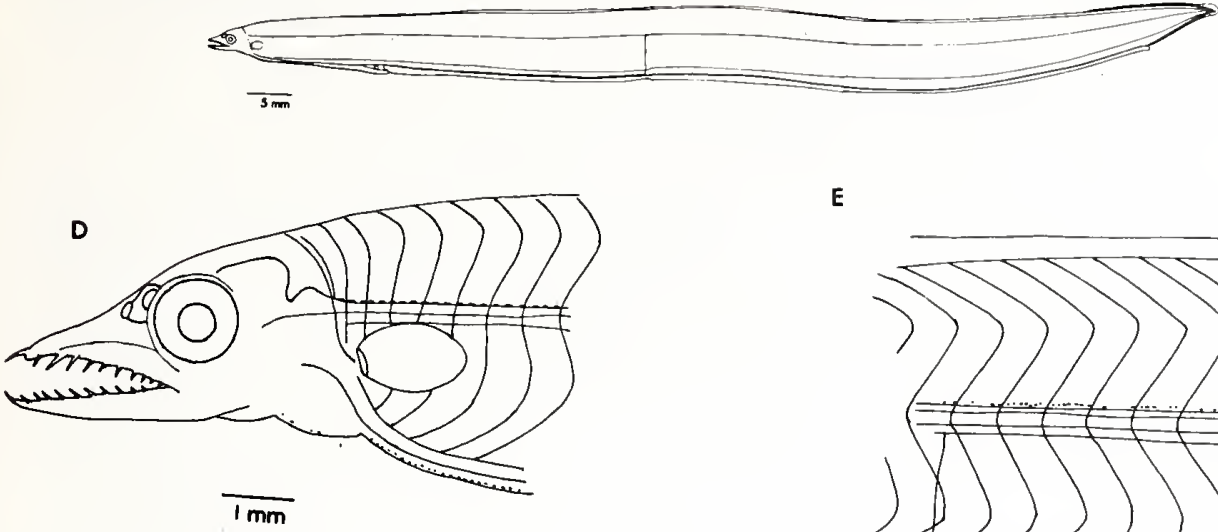

$E$
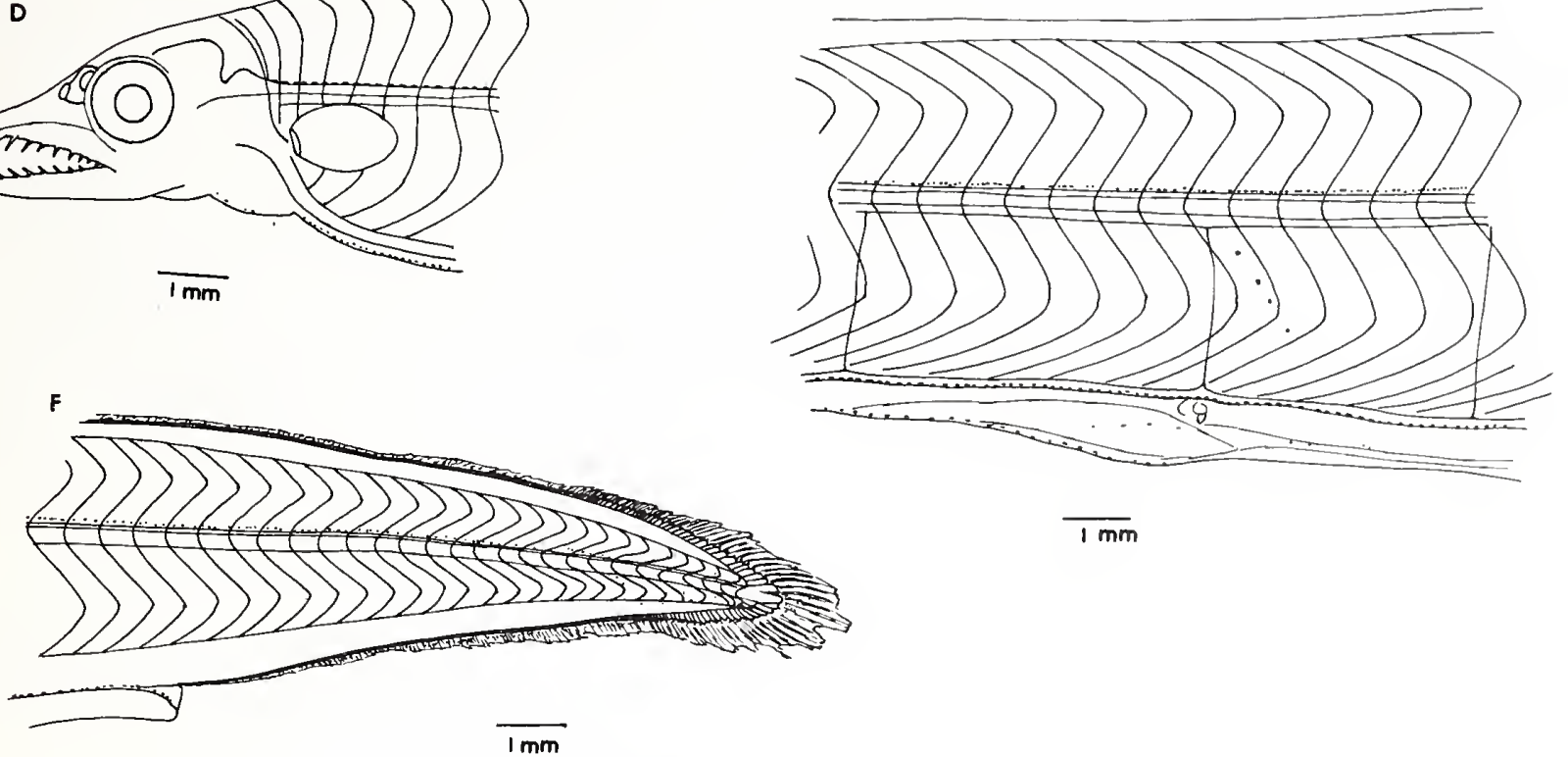

Figure 32.-Nemichthyidae: Avocettina infans (Günther). A. Whole view, $20 \mathrm{~mm} \mathrm{SL}, \mathrm{MBI} 197$. B. Whole view, $45 \mathrm{~mm}$ SL, MBI 47 . C. Whole view, $111 \mathrm{~mm}$ SL, MBI 216. D. Head. E. Gastric region. F. Tail.

Avocettina, but they move dorsally with growth and are unreliable as a diagnostic character. The surest way to distinguish Nemichthys scolopaceus from Avocettina at this stage is by the position of the liver and the last vertical blood vessel. In Nemichthys the posterior end of the liver is located around the 40th myomere and the last vertical blood vessel between the 80 th and 100 th myomere. In Avocettina these structures are at about the 30th and 70th-80th myomere, respectively. Nemichthys scolopaceus later develops an additional pigment spot anterior to the others, but with growth they all become inconspicuous and eventually disappear. Larvae of Nemichthys curvirostris ("Leptocephalus B" of Roule and Bertin) lack these pigment spots at all stages. At standard lengths greater than $100 \mathrm{~mm}$, larvae of $N$. curvirostris have more preanal myomeres (ca. 300-320) than $N$. scolopaceus (ca. 250). Larvae of $N$. larseni are not known. Nemichthys scolopaceus is cosmopolitan, $N$. curvirostris is found in all oceans except the North Pacific, and $N$. larseni is restricted to the northeastern Pacific.

Larvae of Avocettina Jordan and Davis (= Borodinula Whitley) (Fig. 32) are less elongate and have a normal caudal structure. Three groups of lateral pigment spots are present. These are most prominent in young larvae and become less conspicuous with growth. Four species of Avocettina are now recognized: $A$. infans (Günther) (181-201) is found in all oceans north of about lat. $20^{\circ} \mathrm{S}$, A. acuticeps (Regan) (198-216) and A. paucipora Nielsen and Smith (176-188) are found around the world in the Southern Hemisphere, and A. bowersi (Garman) (177-192) is restricted to the eastern tropical Pacific.

Larvae of Labichthys Gill and Ryder have not been described, but since the adults are similar to Avocettina the larvae are probably similar also. Two species of Labichthys exist. Labichthys carinatus Gill and Ryder (174-191) is found in all oceans north of about lat. $20^{\circ} \mathrm{S}$, except the eastern Pacific, but is uncommon throughout. Labichthys yanoi (Mead and Rubinoff) (178-190) occurs in the Southern Hemisphere south of about lat. $20^{\circ} \mathrm{S}$ and is common in high southern latitudes (lat. $50^{\circ}-60^{\circ} \mathrm{S}$ ). 
Avocettinops Roule and Bertin is a synonym of Avocettina, while Nematoprora Gilbert, Cercomitus Weber, and Paravocettinops Kanazawa and Maul are all synonyms of Nemichthys.

References: Roule and Bertin (1929), Beebe and Crane (1937b), Orton (1964a), Castle (1965a), Nielsen and Smith (in press).

\section{Xenocongridae (Figs. 33-34)}

Body moderately deep; gut simple, about one-half standard length or less; dorsal fin long, origin one or two head lengths behind head; ventral pigment variable, composed of large or small melanophores, but always present; lateral pigment variable, always present; sometimes a crescentic patch of pigment under the eye, as in some congrids; maximum size about $90 \mathrm{~mm}$.

This is a small family of shallow-water eels related to the morays. The larvae, however, are more likely to be confused with congrids than anything else. In xenocongrid larvae the gut is never more than half the standard length, whereas in congrids it is always distinctly greater. Congrid larvae are also more elongate. Xenocongrid larvae are homogenous, showing little variation other than in pigmentation and meristic features.

Larvae of Kaupichthys hyoproroides (Strömman) (109-123, $97-98$ in Hawaii, Fig. 33), found throughout the IndoPacific and the western Atlantic, have small melanophores scattered over the entire body, generally lined up along the myosepta. Two other species of Kaupichthys occur in the Indo-Pacific: $K$. atronasus Schultz (114) and $K$. brachychirus Schultz (108-116). If their larvae have the same pigmentation as $K$. hyoproroides, they may well be inseparable from that species and each other. Catesbya pseudomuraena Böhlke and Smith (136-141) from the western Atlantic has a very similar larva, but can be distinguished by the more numerous myomeres.

The larva of the western Atlantic Kaupichthys nuchalis Böhlke (121-125) differs from K. hyoproroides in having the lateral pigment restricted to a series of small melanophores in the postanal region. There is also a scattering of pigment on the head.

The larva of Chilorhinus Lütken (Fig. 34) has a single series of small melanophores along the midlateral line. Two species are recognized: $C$. suensoni Lütken (98-105) from the western Atlantic and C. platyrhynchus (Norman) (107-112) from the Indo-Pacific.
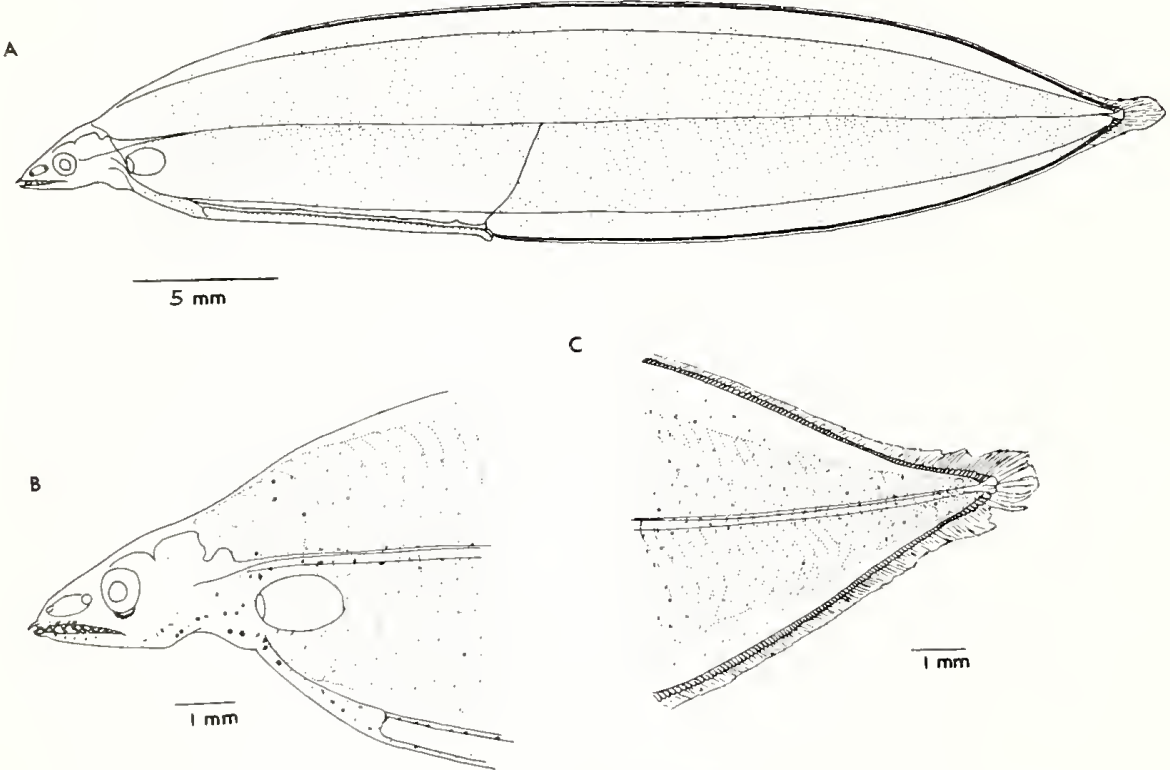

Figure 33.-Xenocongridae: Kaupichthys hyoproroides (Stromman), $38 \mathrm{~mm}$ SL, MBI 26. A. Whole view. B. Head. C. Tail.

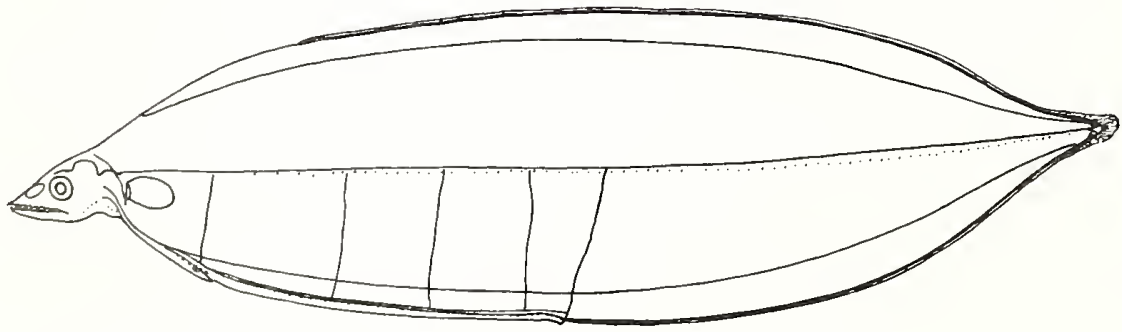

Figure 34.-Xenocongridae: Chilorhinus suensoni Lütken, $31 \mathrm{~mm}$ SL, P 1116. 
Larvae of Chlopsis Rafinesque resemble those of Chilorhinus, but the midlateral melanophores are in an irregular double row. Species are C. bicolor Rafinesque (127-134) from the Mediterranean and the western Atlantic, C. olokun (Robins and Robins) (125-139) from West Africa, C. bicollaris (Myers and Wade) (138-145) and C. apterus (Beebe and Tee-Van) (136) both from the eastern Pacific, and C. dentatus (Seale) (116-124) from the Atlantic and western Indian Oceans. The larva described by Blache (1972) as C. dentatus differs from the others by having the lateral melanophores concentrated in a series of small clusters.

Robinsia catherinae Böhlke and Smith (130-136) from the western Atlantic and western Indian Oceans has several large, expanded melanophores midlaterally and ventrally.

Several other varieties of xenocongrid larvae are known, but only those mentioned above have been identified to genus or species.

References: Spartà (1939b), Orton (1964b), Smith (1969), Blache (1972).

\section{Heterenchelyidae (Fig. 35)}

Body moderately elongate; tail moderately blunt; gut simple, about $80-90 \% \mathrm{SL}$; dorsal fin origin around midlength; head short and deep, becoming blunt-snouted with growth; pectoral fin well developed; a single series of midlateral melanophores extending length of body; a series of ventral melanophores extending length of gut; maximum size 60-70 $\mathrm{mm}$.

Heterenchelyid larvae resemble both congrid and muraenid larvae. Like the Congridae, they have lateral pigment, a well-developed pectoral fin, and a relatively long gut. The short, blunt head is quite muraenidlike. There are no simple key characters that will distinguish heterenchelyid larvae from congrid larvae; they must be recognized individually. The shape of the head is the most distinctive feature.

The center of distribution of the Heterenchelyidae is west Africa, where the species include Pythonichthys microphthalmus (Regan) (110-121), Pythonichthys macrurus (Regan) (124-136), Panturichthys isognathus Poll (149-162), and Panturichthys longus (Ehrenbaum) (209-227). Panturichthys fowleri (Ben Tuvia) (ca. 150) is found in the Mediterranean. There is one species in the western Atlantic, Pythonichthys sanguineus Poey (108), and one in the eastern Pacific, Pythonichthys asodes Rosenblatt and Rubinoff (126-135). The family has not been recorded from the IndoPacific.

Reference: Blache (1977).
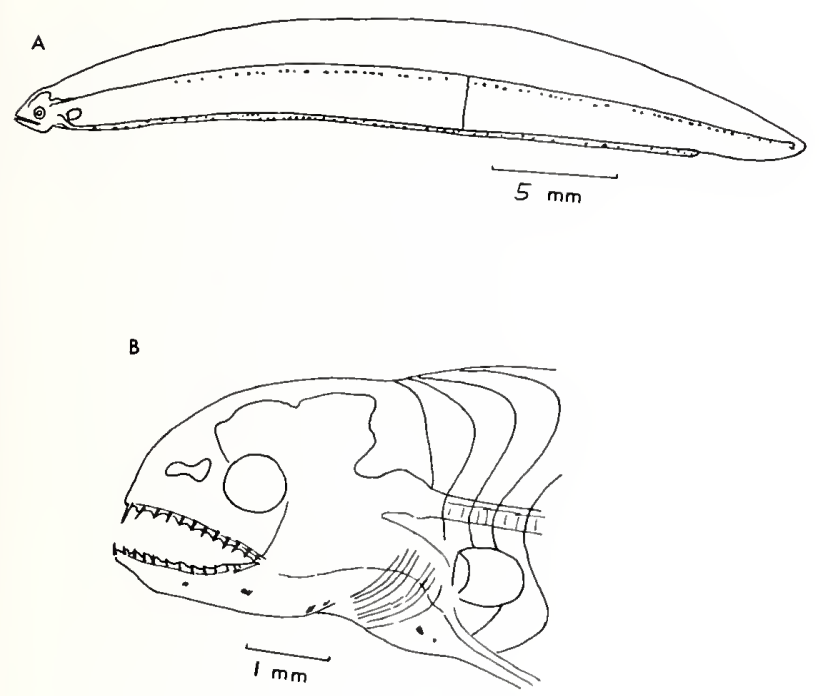

Figure 35.-Heterenchelyidae: Pythonichthys microphthalmus (Regan). A. Whole view, $34 \mathrm{~mm}$ SL. B. Head, $75 \mathrm{~mm}$. After Blache (1977).

\section{Congridae (including Muraenesocidae) (Figs. 36-47)}

Body moderate to elongate; tail variable; gut simple, generally about three-fourths standard length or greater; dorsal fin variable, from very long to very short; ventral pigment variable but always present; lateral pigment variable, sometimes absent; maximum size variable, up to $200-300 \mathrm{~mm}$ in some species, most species probably reach close to $100 \mathrm{~mm}$.

This is one of the largest of the eel families and without doubt the most difficult to characterize, because of the wide variation in almost all important characters. The best way to characterize this family is by elimination: of the eel larvae with a simple gut and ventral pigment, the Muraenidae, Nemichthyidae, Heterenchelyidae, and Xenocongridae can be distinguished by the features given in the accounts of those families. The remainder, presumably, are congrids.

Larvae of several genera and species groups are known. 
Subfamily Bathymyrinae.-Larvae of Ariosoma Swainson (Fig. 36) have a very long gut and the dorsal fin origin near the posterior end of the body. The lateral pigment consists of minute melanophores outlining the myosepta immediately below the midline and forming a series of short diagonal lines from head to tail. The ventral pigment consists of small melanophores below the gut anteriorly, switching to the top of the gut behind the liver. A series of small melanophores lies on the dorsal midline from head to tail. Small specimens have larger, more widely spaced melanophores along the dorsal and ventral midlines (Fig. 36A), but these disappear with growth. Several ophichthids have similar lateral pigment, but they can be distinguished from Ariosoma by the shorter gut with its characteristic swellings or arches. The characteristic pigment of Ariosoma larvae is lost early in metamorphosis; such early metamorphic specimens are fairly common and can be confusing. Four species of Ariosoma are known from the westem North Atlantic: A. balearicum (Delaroche) (120-137), A. selenops Reid (158-174), A. analis (Poey) (146-150), and A. coquettei Smith and Kanazawa $(155-160)$.

A

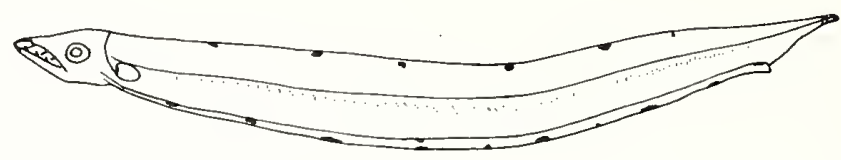

$\overline{1 \mathrm{~mm}}$

B
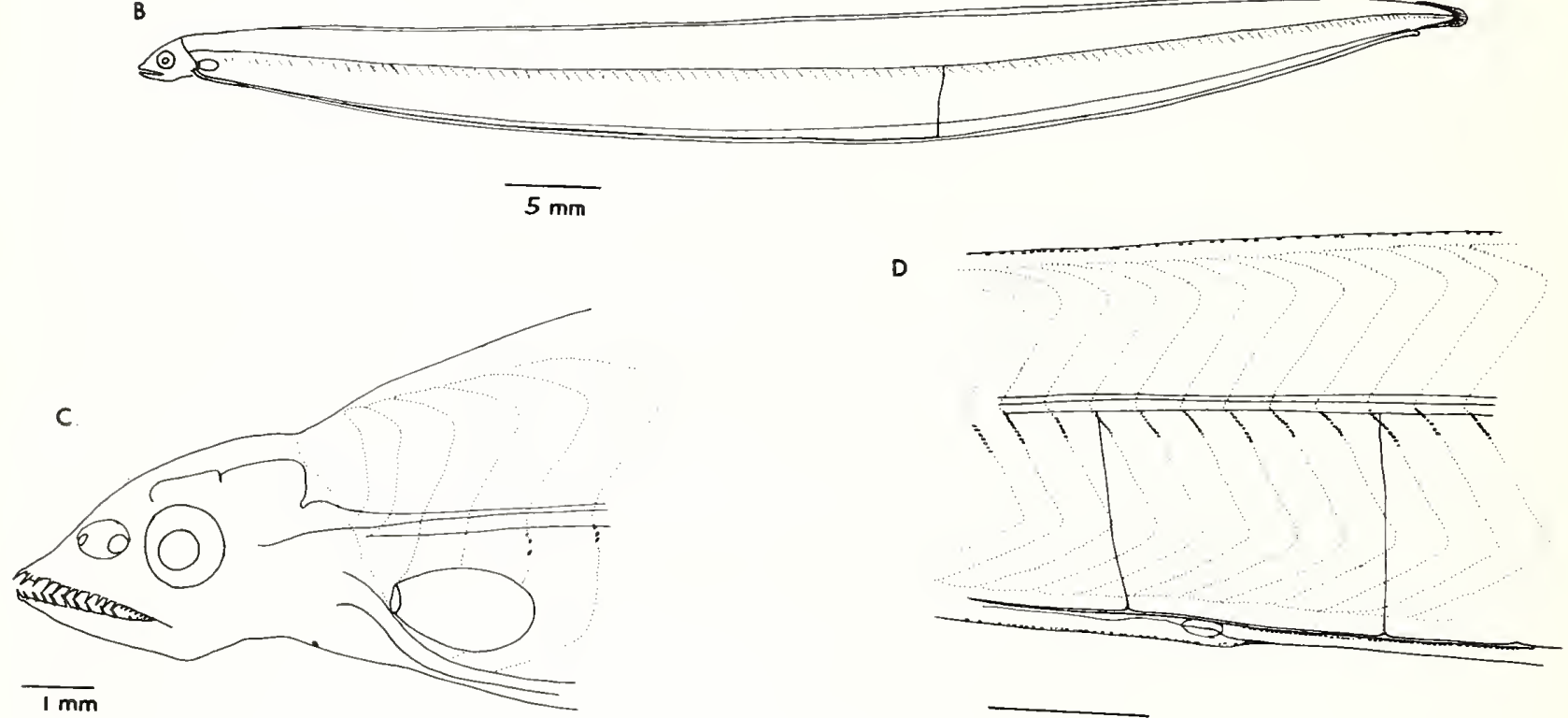

$1 \mathrm{~mm}$

E

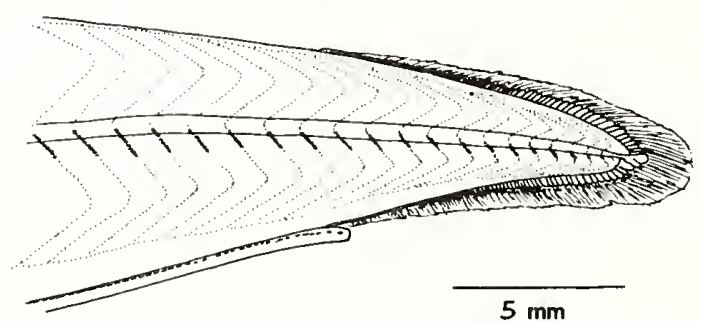

Figure 36.-Congridae, Bathymyrinae: Ariosoma balearicum (Dela roche). A. Whole view, $12 \mathrm{~mm} \mathrm{SL}$, MBI 57-B. B. Whole view, $69 \mathrm{~mm}$ SL, MBI 76. C. Head, $167 \mathrm{~mm} \mathrm{SL,} \mathrm{MBI} \mathrm{203.} \mathrm{D.} \mathrm{Gastric} \mathrm{region,} \mathrm{same.} \mathrm{E.} \mathrm{Tail,} \mathrm{same.}$

Some Ariosoma and Ariosoma-like larvae have the posierior end of the gut extending free of the body (Figs. 36-37). In Ariosoma selenops the free section is short, but in at least two other forms it can exceed the length of the body. The larva described as Leptocephalus scalaris Castle (Fig. 38) has additional pigment along the myosepta above and below the midlateral series and sometimes an oval patch of small melanophores midlaterally around the 50th myomere. The last vertical blood vessel is unusually far back, around the 90th-100th inyomere. Leptocephalus macrenteron D'Ancona (Fig. 37) has only the midlateral series of melanophores outlining the myosepta, and the last vertical blood vessel is 


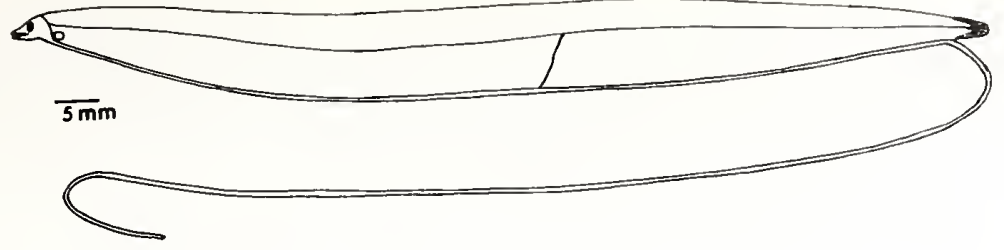

c
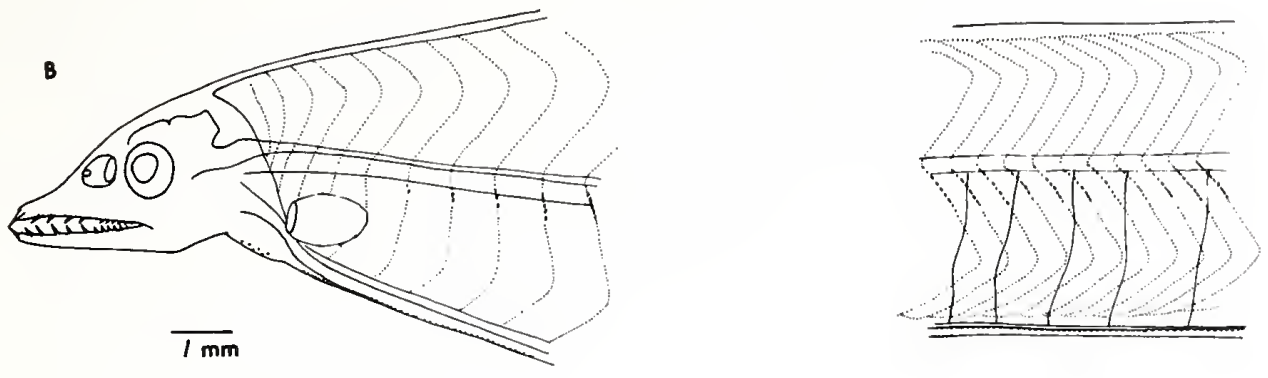

D

$1 \overline{\mathrm{mm}}$

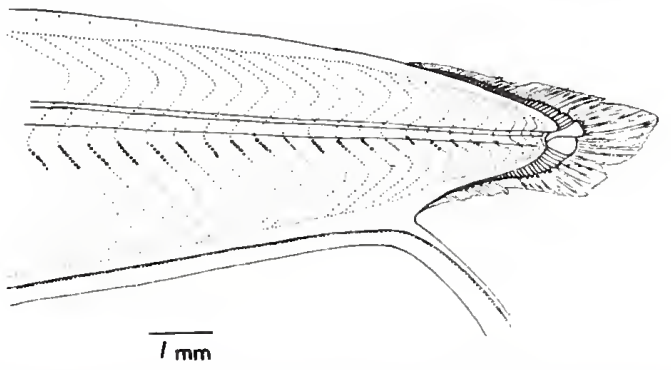

Figure 37.-Congridae, Bathymyrinae: Leptocephalus macrenteron D'Ancona, $111 \mathrm{~mm}$ SL, MBI 242. A. Whole view. B. Head. C. Midbody. D. Tail.

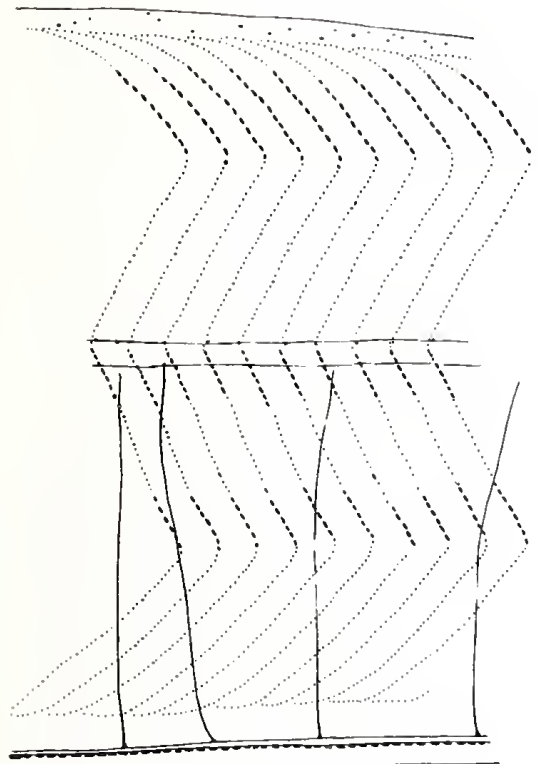

\section{$\overline{\mathrm{I} \mathrm{mm}}$}

Figure 38.-Congridae, Bathymyrinae: Leptocephalus scalaris Castle, $69 \mathrm{~mm}$ SL, MBI 567. Midbody showing lateral pigment.
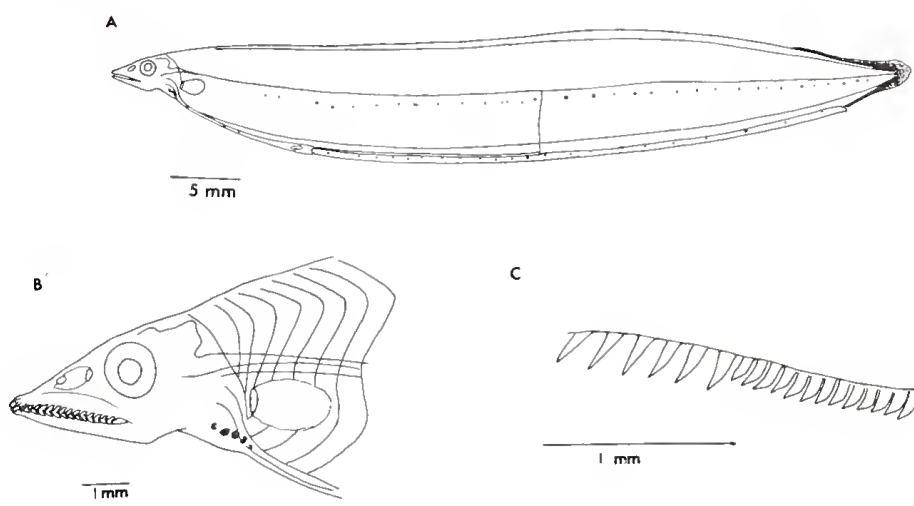

C
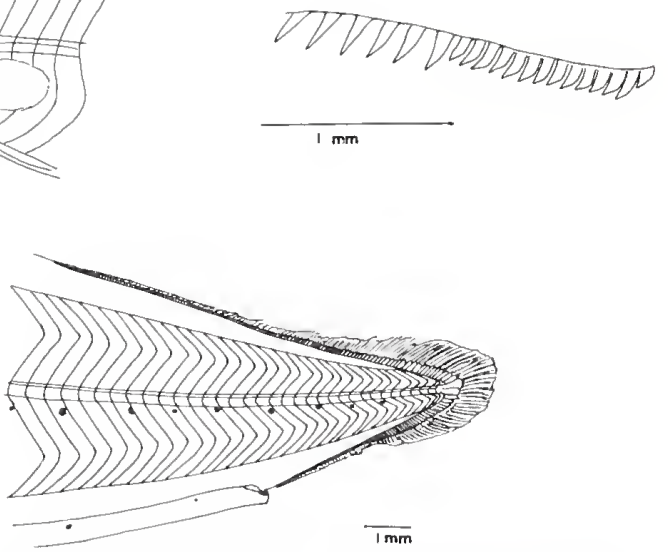

Figure 39.-Congridae, Bathymyrinae: Paraconger caudilimbatus (Poey). A. Whole view, $55 \mathrm{~mm} \mathrm{SL,} \mathrm{MBI} \mathrm{47.} \mathrm{B.} \mathrm{Head,} 59 \mathrm{~mm}$ SL, MBI 55. C. Upper teeth, same. D. Tail, same. 
around the 70th-75th myomere. At the present time the identity of these larvae is uncertain, although Castle (1970a) suggested that $L$. scalaris might be the larva of Bathymyrus Alcock. The last vertical blood vessel, however, is much further back than the first caudal vertebra in adults of Bathymyrus and the similar Parabathymyrus Kamohara (around $70)$. In this character, these two genera are closer to $L$. macrenteron. Based on available evidence, neither $L$. scalaris nor $L$. macrenteron can be confidently identified. Both larvae are found in the Atlantic and Indo-West Pacific and must represent widely distributed genera or species groups.

The larva described tentatively by Castle (1964b) as Alloconger anagoides is similar to larval Ariosoma but has the pigment scattered over the entire lateral body surface.

Paraconger Kanazawa (Fig. 39) belongs to the subfamily Bathymyrinae along with the four genera above, but its larva differs from them in pigmentation. Lateral pigment is a single series of moderate-sized melanophores, less than one per myomere. Ventral pigment is a series of rather widely spaced melanophores. The posterior teeth are broad and bladelike (Fig. 39C). The caudal region resembles that of Ariosoma, and the dorsal fin is short. Paraconger occurs in the eastern and western Atlantic and the eastern Pacific. Three nominal species occur in the western Atlantic: $P$. guianensis Kanazawa (126-131) is found along the coast of South America, while $P$. caudilimbatus (Poey) (121-125) occurs in the Gulf of Mexico, the Bahamas, and the Caribbean. The vertebral counts may overlap more than is indicated above. Paraconger harringtonensis (Mowbray) (123) is known from a single specimen from Bermuda, and may be simply an aberrant specimen of $P$. caudilimbatus.

Subfamily Congrinae.-Larvae of Conger Oken (Fig. 40) usually lack lateral pigment, but occasionally a few melanophores may be present along the midlateral line. Ventral pigment extends the length of the gut and sometimes beyond. A crescentic patch of pigment is present under the eye. Three species of Conger occur in the western North Atlantic. Conger oceanicus (Mitchill) (140-147) occurs mainly, if not entirely, along the continental United States. Conger esculentus Poey (132-133) seems confined to the large islands of the West Indies and Bermuda. Conger triporiceps Kanazawa (156-161) is an insular species occurring from Bermuda south through the Bahamas and the West Indies to Brazil.

A

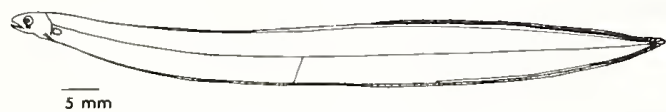

c
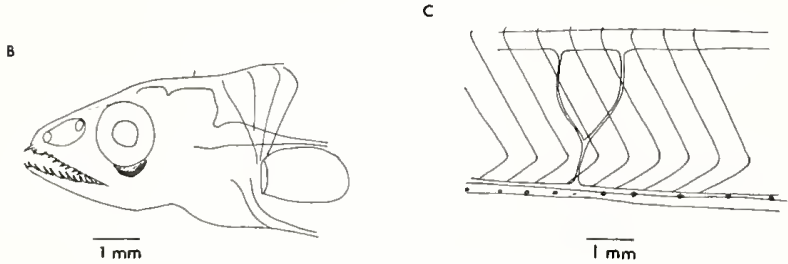

D

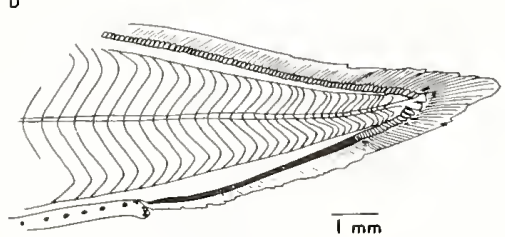

Figure 40.-Congridae, Congrinae: Conger oceanicus (Mitchill), $87 \mathrm{~mm}$ SL, MBI 210. A. Whole view. B. Head. C. Gut; showing ventral pigment. D. Tail.

Larvae of Gnathophis Kaup (Fig. 41) are similar to Conger, differing mainly in the shape of the head, distinctly longer and more sharp-snouted. As in Conger, lateral pigment is usually absent, but sometimes a few small melanophores are present along the midlateral line. Ventral pigment is similar to that of Conger and the same crescentic patch of pigment is present below the eye. The distinction given by Castle (1964b) between larvae of Conger and Gnathophis, i.e., that in Conger the ventral pigment extends posterior to the vent, appears unreliable. Most specimens of Conger from the western Atlantic fail to show the postanal pigment. Three species of Gnathophis are known from the western North Atlantic: G. bracheatopos Smith and Kanazawa (125-130), G. bathytopos Smith and Kanazawa (128-133), and G. tritos Smith and Kanazawa (136-138).

Larvae of Uroconger Kaup, some species of Rhechias Jordan, and Pseudoxenomystax Breder have a single series of midlateral melanophores, a crescentic patch of pigment below the eye, and ventral pigment extending the length of the body. The head is short and the tail is more pointed than that of Conger and Gnathophis. Larvae of Uroconger syringinus Ginsburg (Atlantic) (Fig. 42) and U. lepturus (Richardson) (Indo-Pacific) are recognized by their high myomere counts, above 200. Castle (1969a) showed that the larvae of at least some Indo-Pacific species of Rhechias have three rows of 
A

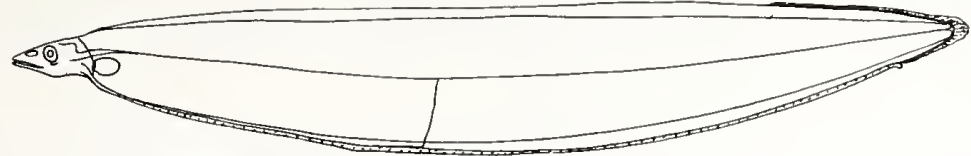

$5 \mathrm{~mm}$

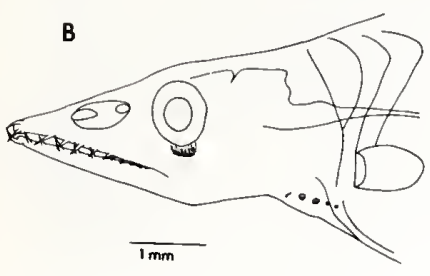

D

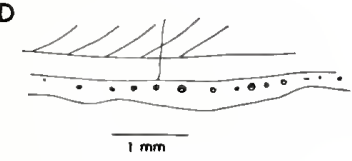

A

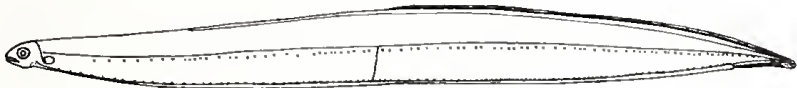

$\overline{5 \mathrm{~mm}}$

c
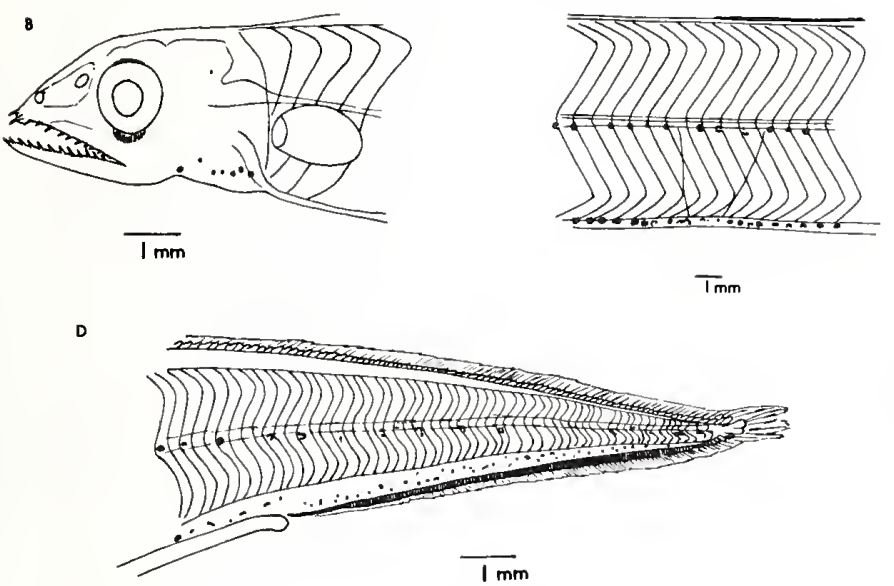

Figure 41.-Congridae, Congrinae: Gnathophis sp., $50 \mathrm{~mm} \mathrm{SL}, \mathrm{P} 809$. A. Whole view. B. Head. C. Gut. D. Tail.

lateral melanophores instead of one (Fig. 43). The western Atlantic species of Rhechias differ only slightly in adult morphology from the Indo-Pacific ones, but pigment retention in juveniles shows that their larvae have only a single row of midlateral melanophores. Three-rowed larvae do occur in the Atlantic, but no adult species can yet be matched with them. Four species of Rhechias are known to occur in the western Atlantic: $R$. thysanochila (Reid) (147-149), $R$. vicinalis (Garman) (170-176), $R$. bullisi Smith and Kanazawa (174-181), and $R$. polypora Smith and Kanazawa (counts unavail-

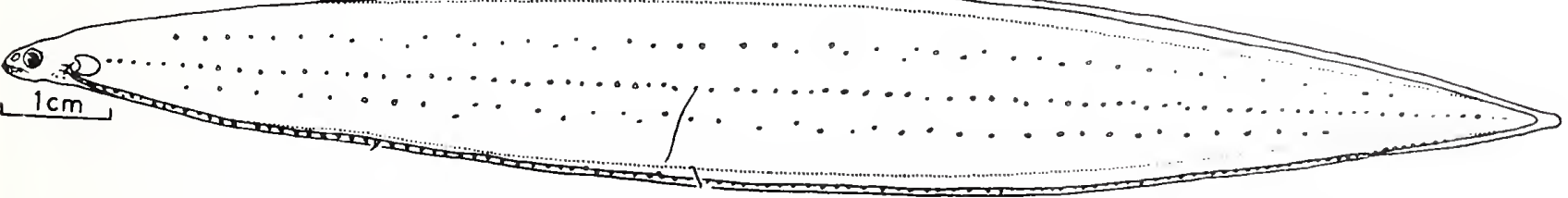

Figure 43.-Congridae, Congrinae: Rhechias guttulata (Günther), $123 \mathrm{~mm}$ TL, from Castle (1969a). 
able). In addition the Pseudoxenomystax dubius Breder complex has a larva almost identical to that of Rhechias. The species composition is uncertain, but the total range of vertebral counts is 123-144.

Pigment retention in juveniles indicates that the larva of Acromycter perturbator (Parr) (157-168) has a single row of midlateral melanophores, but this larva has not yet been found and identified.

Larvae of Hildebrandia Jordan and Evermann have a single row of midlateral melanophores, each of which is slightly beneath the surface of the skin (Fig. 44C). In $H$. flava (Goode and Bean) (153-171, Fig. 44) the midlateral row of pigment is distinctly uneven and there is no crescentic patch of pigment under the eye. Two other species of Hildebrandia are known from the western Atlantic, H. guppyi (Norman) (173-178) and H. gracilior (Ginsburg) (176-182). A second type of Hildeorandia larva occurs in the western Atlantic, but at present it is uncertain which of these species it represents. It has a more even row of midlateral pigment and some inconspicuous pigment beneath the eye. Ophisoma nitens Jordan and Bollman from the eastern Pacific appears to be congeneric with the preceding three species. The Indo-West Pacific Khynchoconger Jordan and Hubbs strongly resembles Hildebrandia and its larva may also be similar. Rhynchoconger ectenurus (Jordan and Richardson) has 155-159 vertebrae, at least in Japanese waters (Asano 1962).

The larva of Pseudophichthys splendens (Lea) (= Promyllantor schmitti Hildebrand) has the lateral pigment distributed over the entire surface of the body in one of the most distinctive patterns found in any leptocephalus (Fig. 45). It has 132-135 vertebrae and is found in both the eastern and western tropical Atlantic. Some specimens have a distinct

A

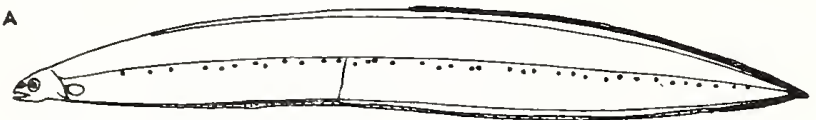
$5 \mathrm{~mm}$

B

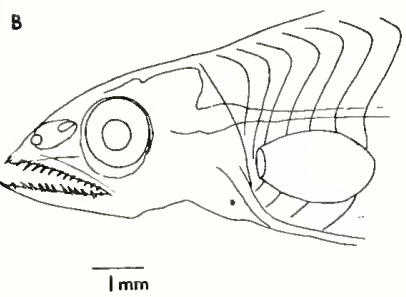

C

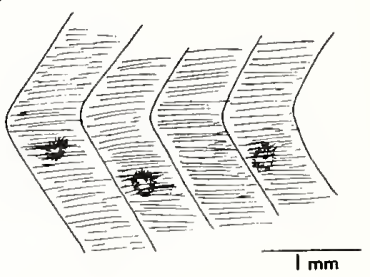

D

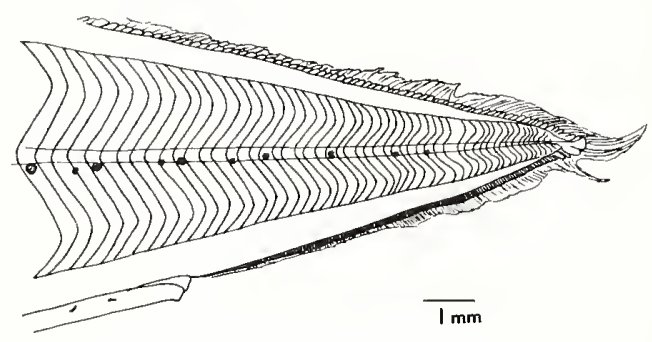

Figure 44.-Congrioae, Congrinae: Hiliebrandic flava (Goode and Bean), $73 \mathrm{~mm}$ SL, MiBI 48. A. Whole view. B. Head. C. Midlateral region snowing subcutaneous melanophores. D. Tail.

A

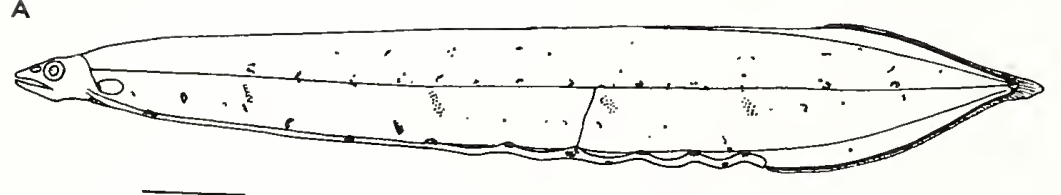

$5 \mathrm{~mm}$
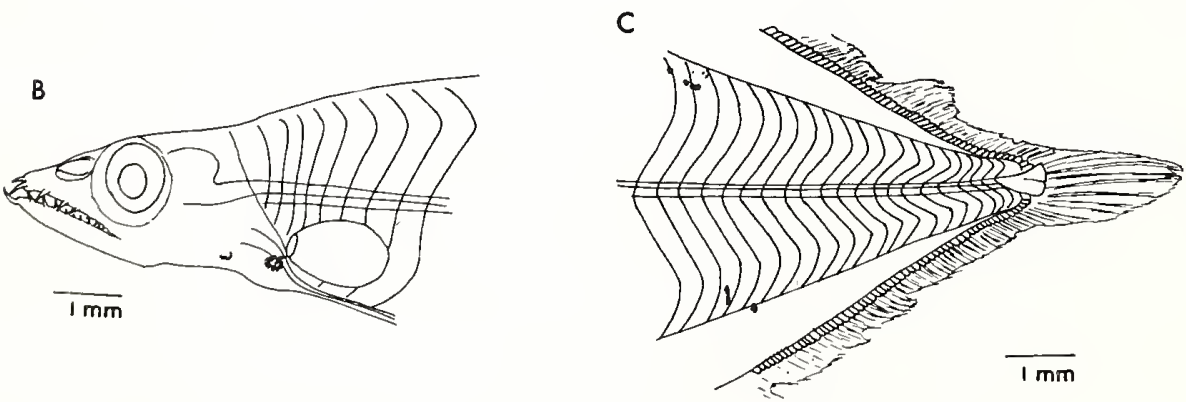

Figure 45.-Congridae, Congrinae: Pseudophichthys splendens (Lea), 50 $\mathrm{mm}$ SL, MBI 214. A. Whole view. B. Head. C. Tail. 
looped pattern to the posterior part of the gut, an uncongridlike feature that could cause confusion when trying to key them out. The prominence of these loops varies individually, being quite obvious in some specimens and hardly apparent in others.

Subfamily Heterocongrinae. - Larvae of the garden eels, Heterocongrinae (Fig. 46), have shorter guts than most congrid larvae, about $67-75 \%$ SL. The dorsal fin begins at about the first quarter of the standard length. The tail is rather blunt, and in more advanced specimens the thickened tip can be seen developing which is used for burrowing by the adult. Lateral pigment is either in a single midlateral row or with additional melanophores along the myosepta below the midlateral line. Four genera are recognized: Heteroconger Bleeker, Taenioconger Herre, Nystactichthys Böhlke, and Gorgasia Meek and Hildebrand. Gorgasia stands apart from the other three, which are closely related to each other. One western Atlantic species is recognized, Nystactichthys halis (Böhlke), which has about 165 vertebrae. Myomere counts among larvae, however, vary from 140 to 167 and more than one species or subspecies may be present.
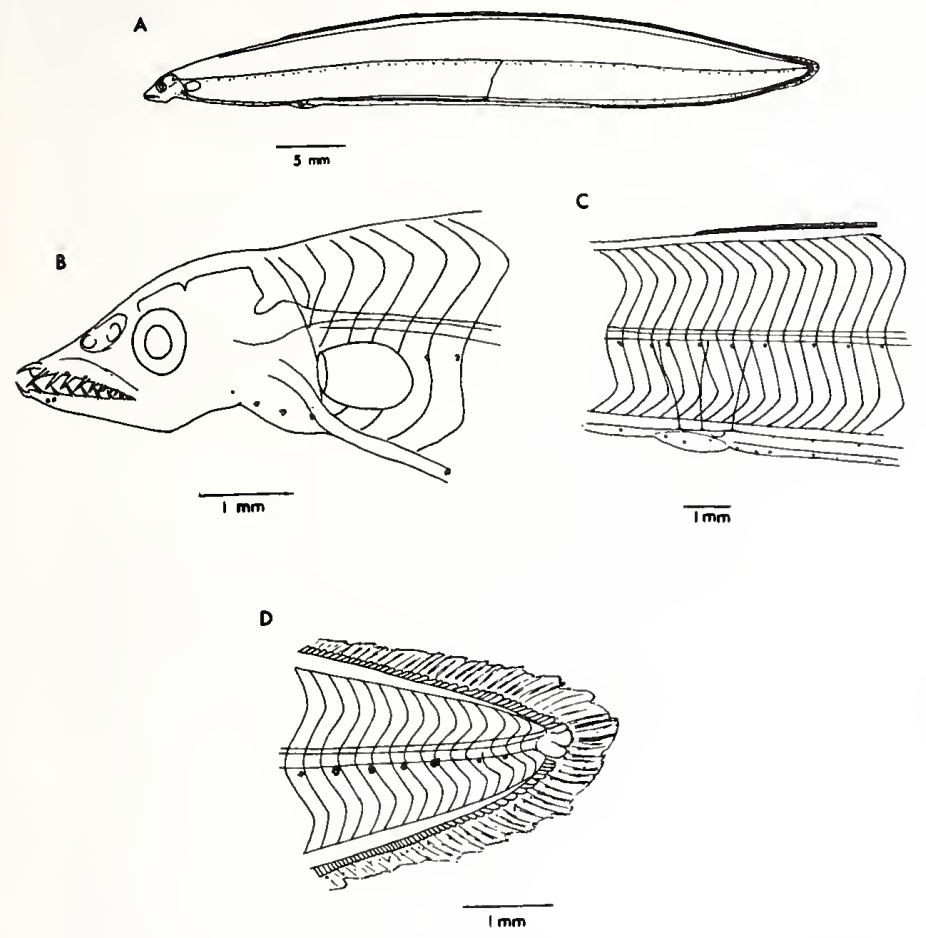

Figure 46.-Congridae, Heterocongrinae: Nystactichthys halis (Bölke), $42 \mathrm{~mm} \mathrm{SL,} \mathrm{MBI} \mathrm{55.} \mathrm{A.} \mathrm{Whole} \mathrm{view.} \mathrm{B.} \mathrm{Head.} \mathrm{C.}$ Gastric region. D. Tail.

Family Muraenesocidae. - The Muraenesocidae is related to the Congridae, but its boundaries are not precisely known.

The larva of a species of Paraxenomystax Reid was described by Blache (1968) (Fig. 47). It has a series of large, expanded lateral melanophores distributed alternately on either side of the body. Ventral pigment is limited to a few large

A

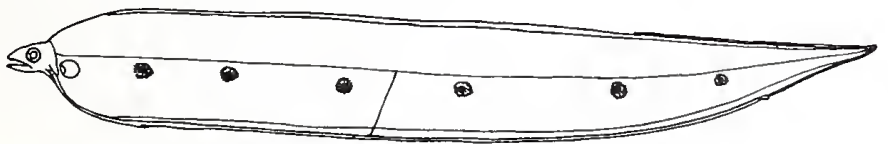

$\overline{5 \mathrm{~mm}}$

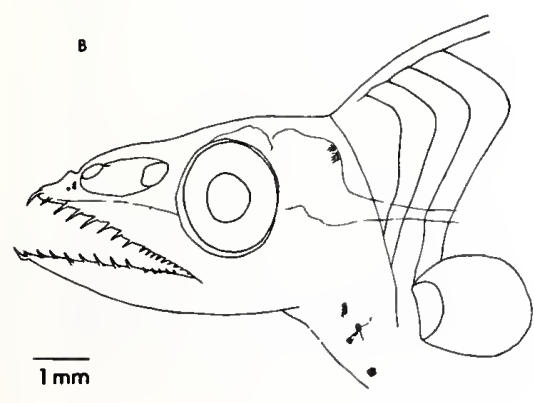

c

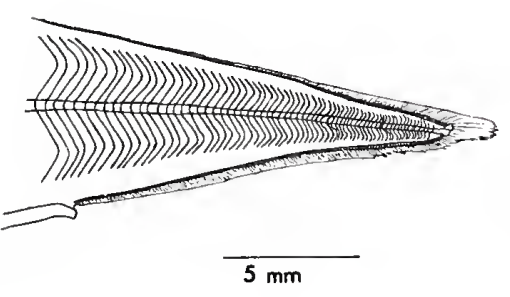

Figure 47.-Muraenesocidae: Paraxenomystax sp., $115 \mathrm{~mm}$ SL, MBI 330 . A. Whole view. B. Head. C. Tail. 
melanophores. The larvae can grow to well over $200 \mathrm{~mm}$. The distinctions between this genus and the related Xenomystax Gilbert are not satisfactorily established, but species are found in all oceans. In the western Atlantic there is one described species, P. bidentatus Reid, and two or three undescribed species. Vertebral numbers range from 170 to about 215. with some north-to-south intraspecific variation.

The larvae of three species of Muraenesox McClelland and Congresox Gill have been described from India. The gut is shorter in these larvae than in Paraxenomystax, about two-thirds to three-fourths standard length.

Nair (1947) described a metamorphosing series of larvae of Muraenesox cinereus (Forsskal) (145-159). The body is moderate and the head is rather long with a characteristic convex dorsal profile above the nasal region. Ventral pigment is irregularly distributed the length of the gut. A single series of expanded melanophores is present midlaterally, one per myomere behind the 17th myomere, with three or four additional melanophores anterior to that point. The number of myomeres in Nair's specimen, 138, suggests that it might be M. bagio (Hamilton) (128-141) rather than cinereus.

Larvae of Congresox talabonoides (Bleeker) (132-145), as described by Nair and Mohamed (1960a), have a more elongate body and a shorter and more acute snout than the preceding. Midlateral melanophores are large and stellate and are distributed every three to four myomeres anteriorly and every two myomeres posteriorly. Ventral melanophores are clustered into a series of six to eight large spots at regular intervals along the length of the gut.

Larvae of Congresox talabon (Cantor) (143-149), also described by Nair and Mohamed (1960b), differ from C. talabonoides mainly in pigmentation. They have a paired row of ventral melanophores on each side of the gut, with a third row above the paired row on the right side. A single row of midlateral melanophores is present.

The larva of Gavialiceps taeniola Alcock (230-261) from the Indo-West Pacific has recently been described. It is elongate with a moderately long head and a pointed tail. About seven pairs of large melanophores are present along the length of the gut. Lateral pigment is absent.

Other genera assigned to the Muraenesocidae include Cynoponticus Costa, Oxyconger Bleeker, and Sauromuraenesox Alcock. Their larvae have not been described. Hoplunnis Kaup has usually been placed in the Muraenesocidae, but its larva is much more like a nettastomatid. Besides the Paraxenomystax group, one other muraenesocid is recorded from the western Atlantic, Cynoponticus savanna (Bancroft) (131-136); its larva is unknown.

Other Congridlike Eels.-Coloconger Alcock is in many ways the most aberrant of all the congroid eels. Castle (1969a) described a metamorphosing specimen of C. raniceps Alcock. It had a double row of ventral melanophores but lacked lateral pigment. The specimen was too far advanced to show many larval characters. The western Atlantic species, C. meadi Kanazawa, has 150-163 vertebrae.

References: D'Ancona (1928), Spartà (1938b), Nair (1947), Nair and Mohamed (1960a, 1960b), Castle (1964b, 1969a, 1977), Blache (1968), Raju (1974b), Castle and Williamson (1975), Keller (1976). In addition N. S. Raju is preparing a manuscript on eastern Pacific congrid larvae.

\section{Macrocephenchelyidae}

This monotypic family (Macrocephenchelys brachialis Fowler 182) is related to the Congridae. It is known from only two specimens, collected near Borneo, and its larva is unknown.

Reference: Robins and Robins (1971).

\section{Myrocongridae}

This monotypic family is known only from the holotype of Myroconger compressus Günther (131), collected at St. Helena in the South Atlantic, and a partial specimen from Dakar, Senegal. It appears to be related to the Muraenidae and Xenocongridae. The larva is unknown.

\section{Unidentified Leptocephali}

Several kinds of leptocephali are known whose peculiarities are so distinctive that they cannot be assigned to any known family.

I. Unnamed (Fig. 18). - Body relatively deep; tail moderate; gut one-half to two-thirds standard length, with a single sharp arch at the posterior end; head moderately short; only pigment a scattering of small melanophores on dorsal aspect of intestinal arch, each melanophore associated with a small bump; dorsal fin origin near midbody; maximum size unknown, at least $63 \mathrm{~mm}$.

Superficially this larva resembles a moringuid, especially Neoconger. Instead of a single or a few expanded melanophores, however, the present larva has a peppering of very small melanophores on the intestinal thickening. Each of these melanophores appears to be located on a small raised bump of tissue. The liver-gall bladder complex is situated anterior to the midpoint of the gut rather than being located just ahead of the intestinal arch as in moringuids. 

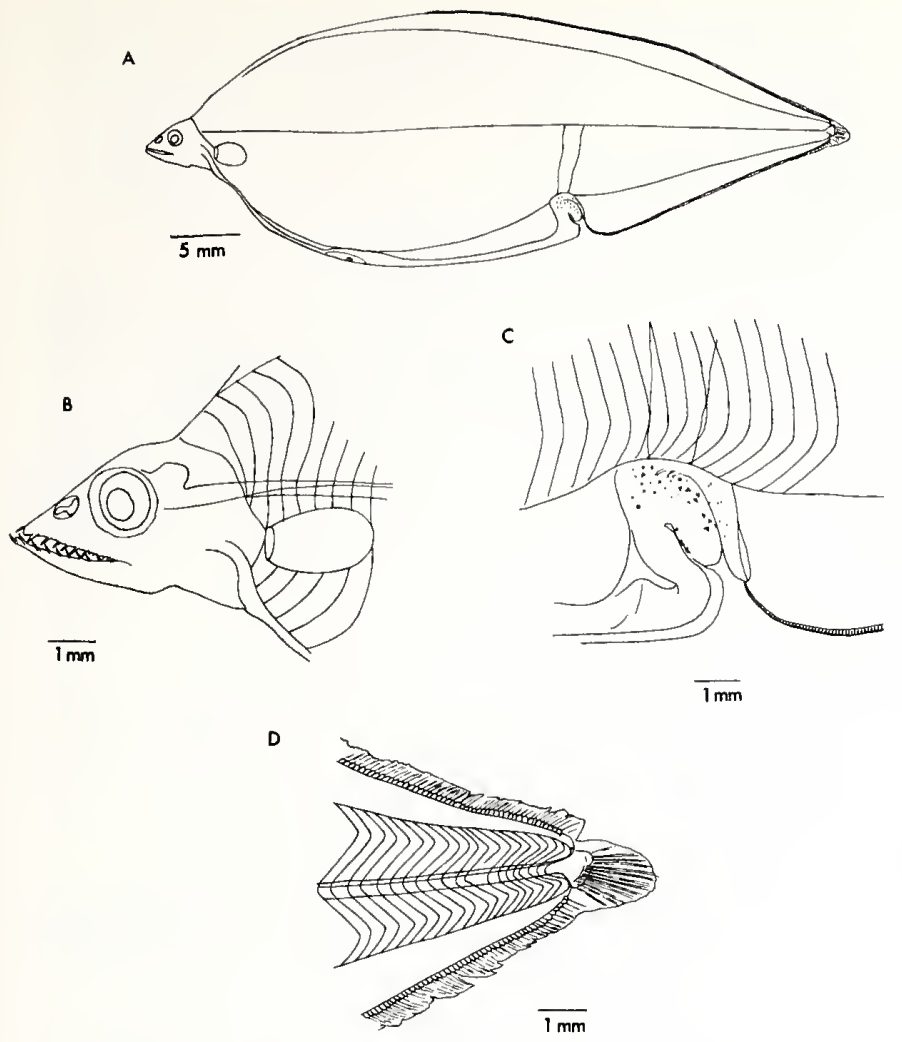

Figure 48.-Unidentified: I, $50 \mathrm{~mm}$ SL, USNS Sands 606-8-T3C+D. A. Whole view. B. Head. C. Anal region. D. Tail.

This larva has not previously been described. The description above is based on a $50-\mathrm{mm}$ specimen with 121 myomeres collected off the coast of Georgia (lat. $31^{\circ} 30^{\prime} \mathrm{N}$, long. $75^{\circ} 25^{\prime} \mathrm{W}$ ). Another specimen of $63 \mathrm{~mm}$ was collected by the Dana (Stn. 3651) near New Zealand; it had 132 myomeres.

II. Unnamed (Fig. 49). - Body moderate; gut less than one-half standard length, with irregular thickenings anteriorly; fleshy keel on nape overhanging head; head with long, pointed snout; nasal organ elongate, about midway between snout tip and eye; relatively large melanophores on gut; a few deep-lying pigment spots on spinal cord; maximum size unknown, at least $66 \mathrm{~mm}$.

Weber (1913) mistakenly identified this larva as Leptocephalus mirabilis Brauer, a dysommine. The short, irregularly thickened gut and the fleshy keel on the nape are the most distinctive features of this larva. The form of the gut and the elongated body are somewhat reminiscent of the nettastomatid genus Facciolella, but this resemblance may or may not be significant. It has been collected from the Indo-Australian region and the western Atlantic.

Reference: Weber (1913).

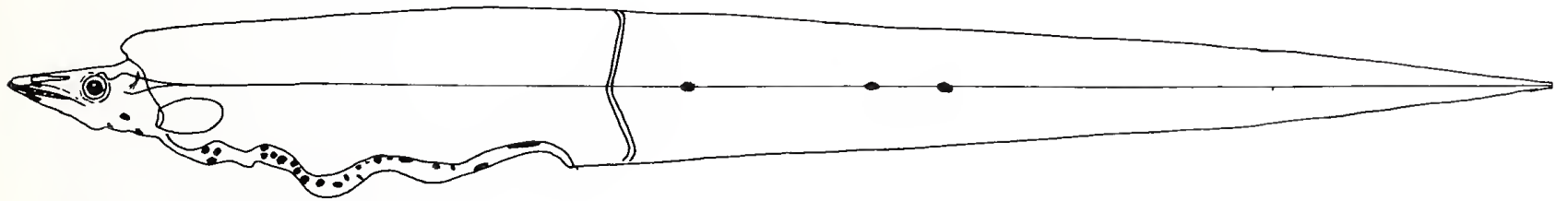

$10 \mathrm{~mm}$

Figure 49.-Unidentified: II, $66 \mathrm{~mm}$ SL, USNS Sands $606-8-T \overline{3}-\mathrm{C}+\mathrm{D}$.

III. Ascomana Castle (Fig8. 50-51).-Body elongate; gut long and simple; dorsal origin behind midlength; pectoral fin well developed; head long; lateral pigment absent; large ventral melanophores from throat to vent; maximum size at least $700 \mathrm{~mm}$.

This is one of the largest of all leptocephali. It shows some muraenesocid features in the head, but its identity is unknown. Two species have been described, A. eximia Castle (153-159) from the Atlantic and A. canina Castle and Raju 

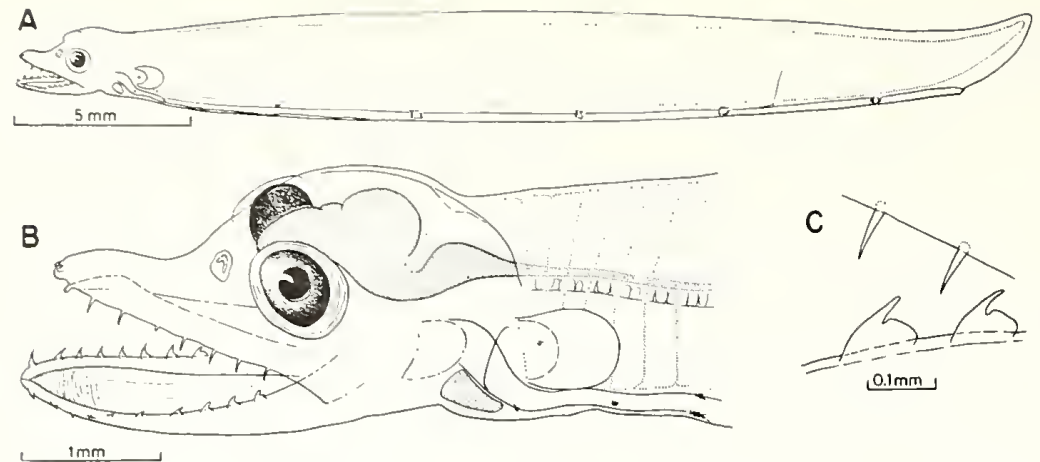

Figure 50.-Unidentified: Ascomana eximia Castle, $29 \mathrm{~mm}$ TL, from Castle and Raju (1975). A. Whole view. B. Head. C. Teeth.

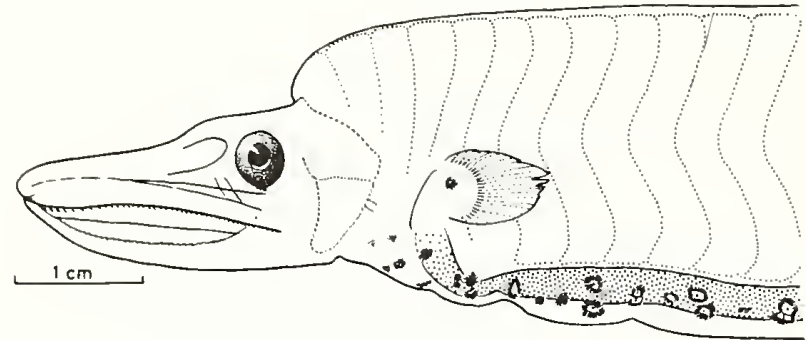

Figure 51.-Unidentified: Ascomana eximia Castle, $700 \mathrm{~mm}$ TL, from Castle (1967).

from the Indian Ocean. The smaller specimens described by Castle and Raju (1975) have a broad snout, shovel-shaped in dorsal profile, and the posterior teeth in the lower jaw have a bicuspid appearance.

References: Castle (1967), Castle and Raju (1975).

IV. Tha lassenchelys Castle and Raju (Fig. 52)._-Body very deep; tail very broadly rounded; head moderately short; gut about one-half standard length, without obvious thickenings or loops; dorsal origin at about midbody; pectoral fin well developed; pigment sparse or absent; maximum size $300 \mathrm{~mm}$.

The large size and truncated tail make this one of the most distinctive of all leptocephali. Castle and Raju referred it to the Xenocongridae, largely by a process of elimination, but this identification seems unlikely. It occurs in the IndoPacific and the eastern Pacific, but appears to be absent from the Atlantic.

References: Cohen (1959), Castle and Raju (1975).

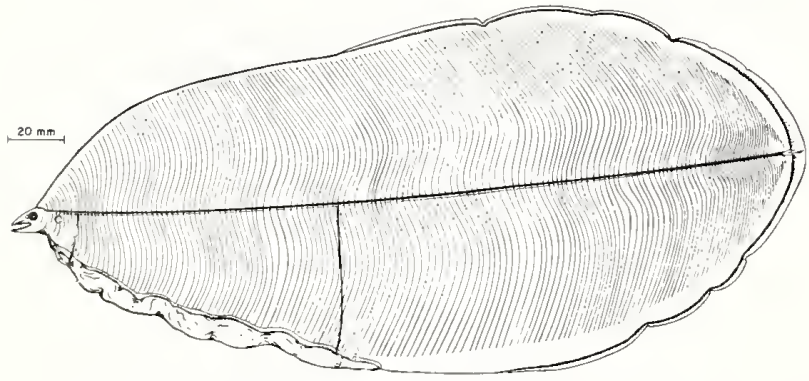

Figure 52.-Unidentified: Thalassenchelys coheni Castle and Raju, $246 \mathrm{~mm}$ TL, from Castle and Raju (1975).

V. Leptocephalus thorianus Schmidt (Fig. 53). - Body moderately deep; gut about two-thirds standard length, relatively thick throughout but without prominent swellings or arches; lateral pigment absent; widely spaced melanophores from liver to vent; maximum size about $90 \mathrm{~mm}$.

This larva (133-143) was originally described as Leptocephalus hyoproroides, a preoccupied name, and was later changed to L. thorianus. It has the major characters of the Congridae, but the true identity is unknown. It was described from the North Atlantic.

A similar form occurs in the Indo-Pacific. It has heavier and more extensive pigment (Fig. 53C, D), but otherwise resembles $L$. thorianus.

Reference: Schmidt (1909).

\section{NOTACANTHIFORMES (Fig. 54)}

Body extremely elongate; tail without normal caudal fin, instead a postcaudal filament; short dorsal fin of about 10 rays located anteriorly around the 40th-50th myomere; small pelvic fins present on large specimens; pectoral fin mi- 

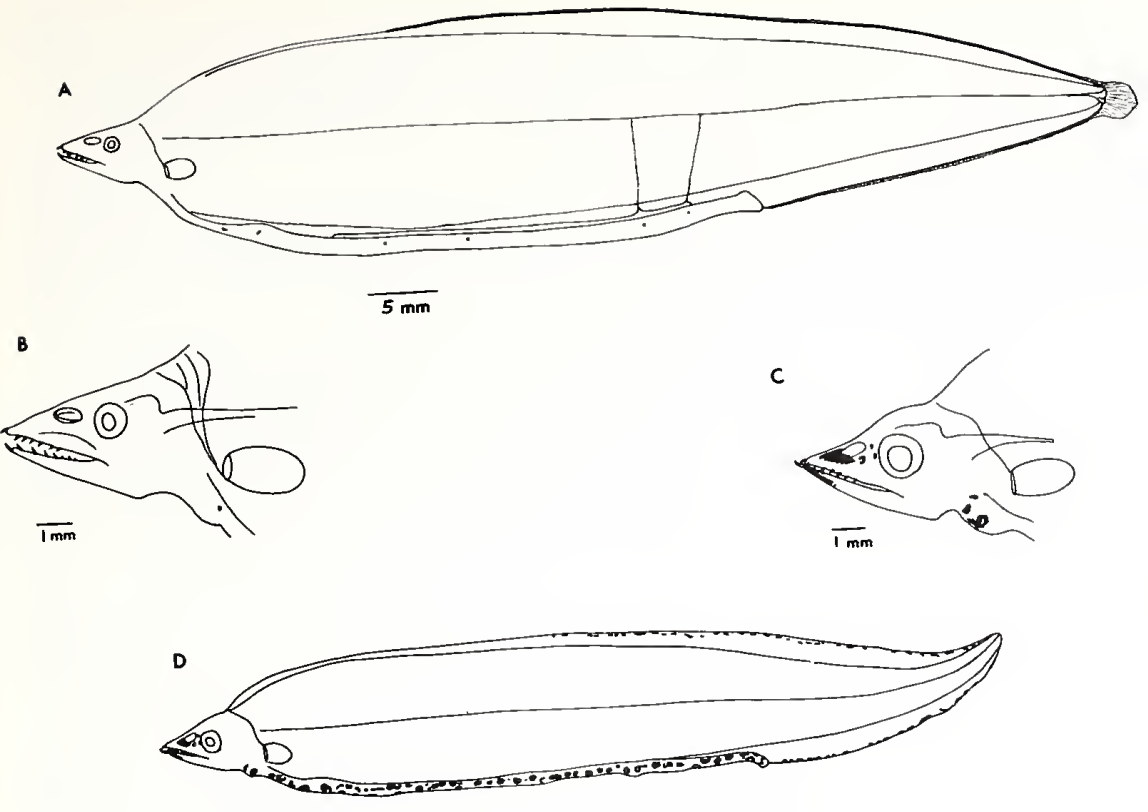

Figure 53.--Unidentified: Leptocephalus thorianus Schmidt. A. Whole view, $73 \mathrm{~mm}$ SL, Dana $4171 \mathrm{~V}$ (Atlantic). B. Head, same. C. Whole view, $59 \mathrm{~mm} \mathrm{SL}$, Dana 3917 VII (Western Pacific). D. Head, same.
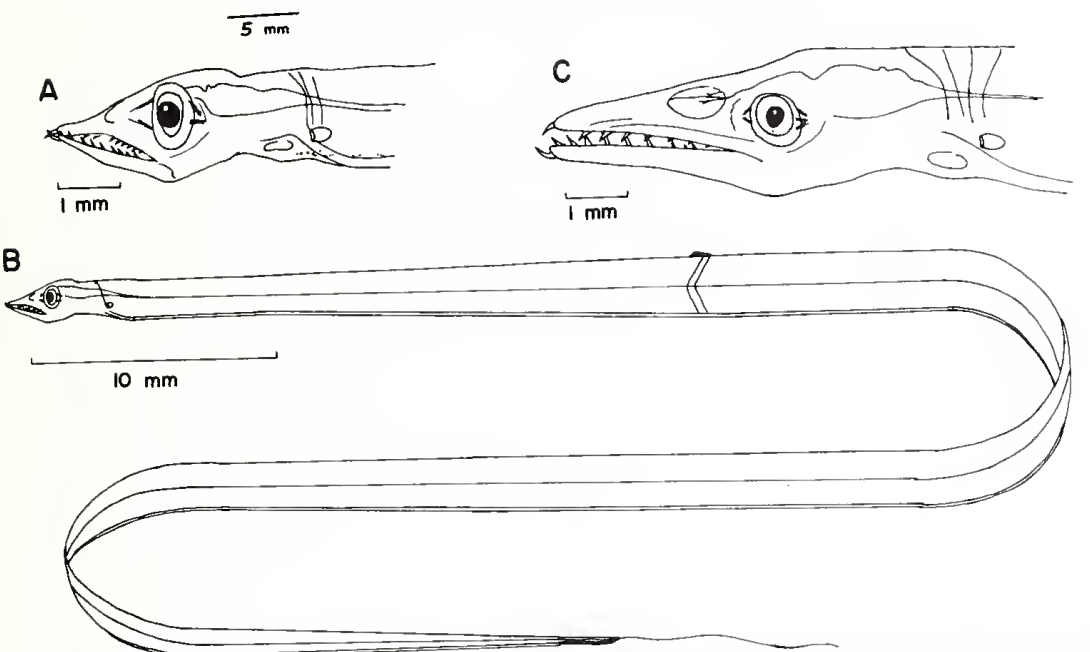

Figure 54.-Notacanthiformes. A. and B. Tiluropsis. C. Leptocephalus giganteus Castle.

nute; gut simple, extending almost entire length of body; ventral pigment variable; lateral pigment usually absent, but small melanophores may be present on myosepta just below midlateral line; myomeres broadly V-shaped, very numerous, 300 or more, maximum size at least $1,800 \mathrm{~mm}$.

Three major types of notacanthiform larvae are known, distinguished mainly by the shape of the head and eye; Tilurus Kölliker has a moderately short head and a round eye; Tiluropsis Roule (Fig. 54A, B) has a moderately short head and a vertically elongated eye; Leptocephalus giganteus Castle (Fig. 54C) has an elongate head and a round eye.

The Notacanthiformes contains three families, the Halosauridae, Notacanthidae, and Lipogenyidae, but it is not certain which larvae represent which families. A comparison of the larvae with the descriptions of metamorphosing specimens by Mead (1965) and Harrisson (1966) strongly suggests that the Tiluropsis form belongs to the Halosauridae (Smith 1970). Beyond that, nothing positive can be said about the identification of the various larvae.

The Tiluropsis type is the most common notacanthiform larva in the western Atlantic. Leptocephalus giganteus is less common. Tilurus has never been reported from the western Atlantic, but appears to be the most common form in the eastern Atlantic and the Mediterranean.

One of the most striking features of notacanthiform larvae is their large size. The 1,800 mm Dana giant leptocephalus was shown by Nielson and Larsen (1970) to be L. giganteus.

The following species of notacanthiform fishes are found in the western North Atlantic. Halosauridae: Halosaurus ovenii Johnson, $H$. guentheri Goode and Bean, Halosauropsis macrochir (Günther), Aldrovandia affinis (Günther), A. gracilis Goode and Bean, $A$. phalacra (Vaillant), A. rostrata (Günther), and $A$. oleosa Sulak. Notacanthidae: Polyacanthonotus africanus (Gilchrist and von Bonde), $P$. rissoanus (DiFilippi and Verany), and Notacanthus chemnitzi Bloch. Lipogenyidae: Lipogenys gilli Goode and Bean. No information is available on vertebral numbers.

References: Castle (1959, 1967), Mead (1965), Harrisson (1966), Nielsen and Larsen (1970), Smith (1970), McDowell (1973). 


\section{ACKNOWLEDGMENTS}

The information in this report comes from a variety of sources: original research, cited published accounts, and unpublished material. I am particularly grateful to James E. and Eugenia B. Böhlke of the Academy of Natural Sciences of Philadelphia for supplying much of the information on vertebral counts of western Atlantic eels and on the species of Muraenidae. J. Blache, Paris, kindly provided me with an advance copy of his treatise on leptocephali of the Gulf of Guinea, which contains the first written account of heterenchelyid larvae. Michael P. Fahay of the NMFS Sandy Hook Laboratory and Aimee Keller of the University of Rhode Island also showed me manuscripts in preparation. Margarita Villoch assisted in the preparation of the illustrations. The National Science Foundation has supported much of the field and laboratory work necessary to bring this report to comple. tion. Among these grants are: NSF-GB-7015, oceanic fishes of the tropical Atlantic, C. R. Robins principal investigator; NFS-GB-17736, eels of the western North Atlantic, James E. Böhlke principal investigator; NSFBMS-75-08675, leptocephali of the Gulf of Mexico, William H. Hulet and David G. Smith principal investigators; NSF-GA-38834, fishes of the Tongue of the Ocean, C. R. Robins principal investigator; NSF-GB-5776, ship time, University of Miami; National Geographic SocietyUniversity of Miami Deep Sea Biology program, Gilbert L. Voss and Frederick M. Bayer principal investigators. The Dana Collections at the University Zoological Museum in Copenhagen were made available by $\mathrm{E}$. Bertelsen and J. Nielsen. Assistance in various forms was also provided by James E. Böhlke, C. Richard and Catherine H. Robins, William J. Richards, and P. H. J. Castle. Elbert H. Ahlstrom deserves a special acknowledgment for his perceptive criticism and encouragement, which contributed greatly to the final quality of this report.

\section{LITERATURE CITED}

ALEXANDER, E. C.

1961. A contribution to the life history, biology and geographical distribution of the bonefish, Albula vulpes (Linnaeus). Dana Rep. 53, 51 p.

ASANO, $\mathrm{H}$.

1962. Studies on the congrid eels of Japan. Bull. Misaki Mar. Biol. Inst., Kyoto Univ. 1, 143 p.

BAUCHOT, M.-L.

1959. Etude des larves leptocéphales du group Leptocephalus lanceolatus Stromman et identification a la famille des Serrivomeridae. Dana Rep. 48, 148 p.

BEEBE, W.

1935. Deep-sea fishes of the Bermuda Oceanographic Expeditions. Family Nessorhamphidae. Zoologica (N.Y.) 20:25-51.

BEEBE, W., and J. CRANE.

1936. Deep-sea fishes of the Bermuda Oceanographic Expeditions. Family Serrivomeridae. Part I: Genus Serrivomer. Zoologica (N.Y.) 20:53-102.

1937a. Deep-sea fishes of the Bermuda Oceanographic Expeditions. Family Serrivomeridae. Part II: Genus Platuronides. Zoologica (N.Y.) 22:331-348.

1937b. Deep-sea fishes of the Bermuda Oceanographic Expeditions. Family Nemichthyidae. Zoologica (N.Y.) 22:349-383.
BERTIN, L.

1937. Les poissons abyssaux du genre Cyema Günther (anatomie, embryologie, bionomie). Dana Rep. 10, 30 p.

1938. Formes nouvelles et formes larvaires de poissons apodes appartenant au sous-ordre des Lyomères. Dana Rep. 15, 26 p.

BLACHE, J.

1963. Contribution à la connaissance des poissons anguilliformes de la côte occidental d'Afrique. Septieme note: la famille des Muraenesocidae. Bull. Inst. Fondam. Afr. Noire, Ser. A Sci. Nat. 30:690-736.

1971. Larves leptocéphales des poissons anguilliformes dans le Golfe de Guinée (zone sud). $1^{\text {re }}$ note: Larves de Muraenidae. Cah. O.R.S.T.O.M. Ser. Oceanogr. 9:203-246.

1972. Larves leptocéphales des poissons anguilliformes dans le Golfe de Guinée (zone sud). $2^{e}$ note: Les especes adultes de Xenocongridae et leurs larves. Cah. O.R.S.T.O.M. Ser. Oceanogr. 10:219-241.

1977. Leptocéphales des poissons anguilliformes dans la zone sud du Golfe de Guinée. Faune Tropicale 20, 381 p.

BLACHE, J., G. E. MAUL, and L. SALDANHA.

1970. Presence d'adulte et des larves de Nettodarus brevirostris et de Nettodarus sp. dans l'Atlantique oriental. Arq. Mus. Bocage, 2 Sér. 2:319-331.

BOHLKE, J. E.

1966. Order Lyomeri. Deep-sea gulpers. In Fishes of the Western North Atlantic. Mem. Sears Found. Mar. Res. 1(part 5):603628.

BRUUN, A. F

1937. Contributions to the life histories of the deep sea eels: Synaphobranchidae. Dana Rep. 9, 31 p.

CASTLE, P. H. J.

1959. A large leptocephalid (Teleostei, Apodes) from off South Westland, New Zealand. Trans. R. Soc. N.Z. 87:179-184.

1963. Anguillid leptocephali in the southwest Pacific. Zool. Publ., Victoria Univ., Wellington 33:1-14.

1964a. Deep-sea eels: family Synaphobranchidae. Galathea Rep. $7: 29-42$.

1964b. Congrid leptocephali in Australasian waters with descriptions of Conger wilsoni ( $\mathrm{Bl}$. and $\mathrm{Schn}$.) and $C$. verreauxi Kaup. Zool. Publ., Victoria Univ., Wellington 37, 45 p.

1964c. Eels and eel-larvae of the Tui oceanographic cruise 1962, to the South Fiji Basin. Trans. R. Soc. N.Z., Zool. 5:71-84.

1965a. Leptocephali of the Nemichthyidae, Serrivomeridae, Synaphobranchidae and Nettastomidae in Australasian waters. Trans. R. Soc. N.Z., Zool. 5:131-146.

1965b. Muraenid leptocephali in Australasian waters. Trans. R. Soc. N.Z., Zool. 7:57-84.

1965c. Ophichthid leptocephali in Australasian waters. Trans. R. Soc. N.Z., Zool. 7:97-123.

1965d. Moringuid leptocephali in Australasian waters. Trans. R. Soc. N.Z., Zool. 7:125-133.

1967. Two remarkable eel-larvae from off southern Africa. Rhodes Univ., Dep. Ichthyol., Spec. Publ. 1, 12 p.

1969a. The eel genera Congrina and Coloconger off southern Mozambique and their larval forms. Rhodes Univ., Dep. Ichthyol., Spec. Publ. 6, 10 p.

1969b. An index and bibliography of eel larvae. Rhodes Univ., Dep. Ichthyol., Spec. Publ. 7, 121 p.

1970a. Ergebnisse der Forschungsreisen des FFS "Walther Herwig" nach Südamerika. XI. The leptocephali. Arch. Fischereiwiss. 21:1-21.

1970b. Distribution, larval growth, and metamorphosis of the eel Derichthys serpentinus Gill, 1884 (Pisces: Derichthyidae). Copeia 1970:444-452.

1977. Leptocephalus of the Muraenesocid eel Gavialiceps taeniola. Copeia 1977:488-492.

CASTLE, P. H. J., and J. E. BOHLKE.

1976. Sexual dimorphism in size and vertebral number in the western Atlantic eel Moringua edwardsi (Anguilliformes: Moringuidae). Bull. Mar. Sci. 26:615-619.

CASTLE, P. H. J., and N. S. RAJU.

1975. Some rare leptocephali from the Atlantic and Indo-Pacific Oceans. Dana Rep. 85, 25 p. 
CASTLE, P. H. J., and G. R. WILLIAMSON.

1975. Systematics and distribution of eels of the Muraenesox group (Anguilliformes, Muraenesocidae). A preliminary report and key. J. L. B. Smith Inst. Ichthyol., Rhodes Univ., South Africa, Spec. Publ. 15, 9 p.

COHEN, D. M.

1959. A remarkable leptocephalus from off the coast of Washington. Deep-Sea Res. 5:238-240.

D'ANCONA, U.

1928. Murenoidi (Apodes) del Mar Rosso e del Golfo di Aden. Materiali raccolti dal Prof. Luigi Sanzo nella campagna della R.N. "Ammiraglio Magnaghi" 1923-1924. Mem. R. Com. Talassogr. Ital. 146, $146 \mathrm{p}$.

1931. Ordine Apodes. In Uova, larve e stadi giovanili di teleostei. Fauna e Flora del Golfo de Napoli, Monogr. 38:94-156.

DEAN, D. M.

1968. The metamorphosis of the ophichthid eel Myrophis egmontis. M.S. Thesis, Univ. Miami, 49 p.

ELDRED, B.

1966. The early development of the spotted worm eel, Myrophis punctatus Lütken (Ophichthidae). Fla. Board Conserv. Mar. Lab., Leafl. Ser., Vol. 4, part 1 (1), 13 p.

1967a. Larval bonefish, Albula vulpes (Linnaeus, 1758), (Albulidae) in Florida and adjacent waters. Fla. Board Conserv. Mar. Lab., Leafl. Ser., Vol. 4, part 1 (3), 4 p.

1967b. Larval tarpon, Megalops atlanticus Valenciennes, (Megalopidae) in Florida waters. Fla. Board Conserv. Mar. Lab., Leafl. Ser., Vol. 4, part 1 (4), 9 p.

1967c. Eel larvae, Leptocephalus tuberculatus Castle, 1965, (Moringuidae) in South Atlantic waters. Fla. Board Conserv. Mar. Lab., Leafl. Ser., Vol. 4, part 1 (5), 6 p.

1968a. The eel larva, Leptocephalus Moringua edwardsi (Jordan and Bollman, 1889) (Moringuidae) in the Florida Straits. Fla. Board Conserv. Mar. Lab., Leafl. Ser., Vol. 4, part 1 (6), 5 p.

1968b. Larvae of the marbled moray eel, Uropterygius juliae (Tommasi, 1960). Fla. Board Conserv. Mar. Lab., Leafl. Ser., Vol. 4, part $2(8), 4 \mathrm{p}$.

1968c. Larvae and glass eels of the American freshwater eel, Anguilla rostrata (Lesueur, 1817), in Florida waters. Fla. Board Conserv. Mar. Lab., Leafl. Ser., Vol. 4, part 1 (9), 4 p.

1968d. The larval development and taxonomy of the pigmy moray eel, Anarchias yoshiae Kanazawa 1952. Fla. Board Conserv. Mar. Lab., Leafl. Ser., Vol. 4, part 1 (10), 8 p.

1969a. The larva of the redface moray, Rabula acuta (Parr, 1930) Böhlke and Chaplin, 1968. Fla. Dep. Nat. Resour. Mar. Lab., Leafl. Ser., Vol. 4, part 1 (11), no pagination.

1969b. Embryology and larval development of the blackedge moray, Gymnothorax nigromarginatus (Girard, 1859). Fla. Dep. Nat. Resour. Mar. Lab., Leafl. Ser., Vol. 4, part 1 (13), no pagination.

1970. Larva of the spotted moray, Gymnothorax moringa (Cuvier, 1829). Fla. Dep. Nat. Resour. Mar. Lab., Leafl. Ser., Vol. 4, part 1 (15), $10 \mathrm{p}$.

1972. Note on larval tarpon, Megalops atlanticus (Megalopidae), in the Florida Straits. Fla. Dep. Nat. Resour. Mar. Lab., Leafl. Ser., Vol. 4, part 1 (22):1-6.

ELDRED, B., and W. G. LYONS.

1966. Larval ladyfish, Elops saurus Linnaeus 1766, (Elopidae) in Florida and adjacent waters. Fla. Board Conserv. Mar. Lab., Leafl. Ser., Vol. 4, part 1 (2), no pagination.

FAHAY, M. P., and C. L. OBENCHAIN.

In press. Leptocephali of the ophichthid genera Ahlia, Myrophis, Ophichthus, Pisodonophis, Callechelys, Letharchus and Apterichtus on the Atlantic continental shelf of the United States. Bull. Mar. Sci.

GEHRINGER, J. W.

1959. Early development and metamorphosis of the ten-pounder, Elops saurus Linnaeus. U.S. Fish Wildl. Serv., Fish. Bull. 59:619-647.

GRASSI, G. B.

1913. Metamorfosi dei muraenoidi. Ricerche sistematiche ed ecologische. Jena: Fischer, 211 p.
HARRISSON, C. M. H.

1966. On the first halosaur leptocephalus: from Madeira. Bull. Br. Mus. (Nat. Hist.) Zool. 14:445-486.

HILDEBRAND, S. F.

1963. Family Elopidae. In Fishes of the Western North Atlantic. Mem. Sears Found. Mar. Res. 1(part 3):111-131.

JESPERSEN, P.

1942. Indo-Pacific leptocephalids of the genus Anguilla. Systematic and biological studies. Dana Rep. 22, 127 p.

KELLER, A.

1976. Systematics, vertical distribution, and life history of anguilliform leptocephali in the Bermuda Ocean Acre. M.S. Thesis,

LEA, E. Univ. Rhode Island, Kingston, 256 p.

1913. Muraenoid larvae from the "Michael Sars" North Atlantic Deep-sea Expedition 1910. Rep. Sci. Res. "Michael Sars" North Atl. Deep-sea Exped. 3(1):1-48.

McDOWELL, S. B.

1973. Order Heteromi (Notacanthiformes). In Fishes of the Western North Atlantic. Mem. Sears Found. Mar. Res. 1(part 6):1 228.

MEAD, G. W.

1965. The larval form of the Heteromi (Pisces). Breviora 226, $5 \mathrm{p}$.

NAIR, R. V.

1947. On the metamorphosis of two leptocephali from the Madras plankton. Proc. Indian Acad. Sci. 25B:1-14.

NAIR, R. V., and K. H. MOHAMED.

1960a. Studies on the leptocephali of Bombay waters. I. The metamorphosing stages of Muraenesox talabonoides (Bleeker). Proc. Indian Acad. Sci. 52B:147-168.

1960b. Studies on the leptocephali of Bombay waters. II. The metamorphosing stages of Muraenesox talabon (Cantor). Proc. Indian Acad. Sci. 52B:169-181.

NIELSEN, J. G., and V. LARSEN

1970. Remarks on the identity of the giant Dana eel-larva. Vidensk. Medd. Dan. Naturhist. Foren. Kbh. 133:149-157.

NIELSEN, J. G., and D. G. SMITH.

In press. The eel family Nemichthyidae. Dana Rep.

ORTON, G. L.

1963. Notes on larval anatomy of fishes of the order Lyomeri. Copeia 1963:6-15.

1964a. Identification of Leptocephalus acuticeps Regan as the larva of the eel genus Avocettina. Pac. Sci. 18:186-201.

1964b. New information on a rare eel larva, Leptocephalus hyoproroides Strömman. Copeia 1964:434-444.

RAJU, N. S., and R. H. ROSENBLATT.

1971. New record of the parasitic eel, Simenchelys parasiticus from the central North Pacific with notes on its metamorphic form. Copeia 1971:312-314.

RAJU, S. N.

1974a. Three new species of the genus Monognathus and the leptocephali of the order Saccopharyngiformes. Fish. Bull., U.S. $72: 547-562$.

1974b. Distribution, growth and metamorphosis of leptocephali of the garden eels, Taenioconger sp. and Gorgasia sp. Copeia 1974:494-500.

RASQUIN, P.

1955. Observations on the metamorphosis of the bonefish, Albula vulpes (Linnaeus). J. Morphol. 97:77-117.

RICHARDS, W. J.

1969. Elopoid leptocephali from Angolan waters. Copeia 1969:515-518.

RICHARDSON, S. L.

1974. Eggs and larvae of the ophichthid eel, Pisodonophis cruentifer, from the Chesapeake Bight, Western North Atlantic. Chesapeake Sci. 15:151-154.

RIVAS, L. R., and S. M. WARLEN.

1967. Systematics and biology of the bonefish, Albula nemoptera (Fowler). U.S. Fish Wildl. Serv., Fish. Bull. 66:251-258.

ROBINS, C. H.

1971. The comparative morphology of the synaphobranchid eels of the Straits of Florida. Proc. Acad. Nat. Sci. Phila. 123:153-204. 
ROBINS, C. H., and C. R. ROBINS.

1970. The eel family Dysommidae (including the Dysomminidae and Nettodaridae), its osteology and composition, including a new genus and species. Proc. Acad. Nat. Sci. Phila. 122:293335.

1971. Osteology and relationships of the eel family Macrocephenchelyidae. Proc. Acad. Nat. Sci. Phila. 123:127-150.

1976. New genera and species of dysommine and synaphobranchine eels (Synaphrobranchidae) with an analysis of the Dysomminae. Proc. Acad. Nat. Sci. Phila. 127:249-280.

ROULE, L., and L. BERTIN.

1929. Les poissons apodes appartenant au sous-ordre des Nemichthydiformes. Danish "Dana"-Expeditions 1920-22, 4, $113 \mathrm{p}$.

SANZO, L

1938. Uova, stadi embrionali, prelarve e larve di Saurenchelys cancrivora Peters. Mem. R. Comm. Talassogr. Ital. 249, 10 p.

SCHMIDT, J.

1909. On the occurrence of leptocephali (larval muraenoids) in the Atlantic w. of Europe. Medd. Komm. Havunders., Ser. Fisk. 3(6), $19 \mathrm{p}$.

1925. The breeding places of the eel. Annu. Rep. Smithson. Inst. 1924:279-316.

1930. Nessornamphus, a new cosmopolitan genus of oceanic eels. Vidensk. Medd. Dan. Naturhist. Foren. Kbh. 90:371-376.

1931. Oceanographical expedition of the Dana, 1928-30. Nature (Lond.) 127:444-446, 487-490.

SMITH, D. G.

1968. The occurrence of larvae of the American eel, Anguilla rostrata, in the Straits of Florida and nearby areas. Bull. Mar. Sci. 18:280-293.

1969. Xenocongrid eel larvae in the western North Atlantic. Bull. Mar. Sci. 19:377-408.

1970. Notacanthiform leptocephali in the western North Atlantic. Copeia 1970:1-19.

1974. Dysommid eel larvae in the western North Atlantic. Copeia 1974:671-680.
SMITH, D. G., and P. H. J. CASTLE.

1972. The eel genus Neoconger Girard: systematics, osteology, and life history. Bull. Mar. Sci. 22:196-249.

SMITH, J. L. B.

1966. Hitherto unknown early developmental larval stadia of the west African albulid fish, Pterothrissus belloci Cadenat, 1937. Rhodes Univ., Dep. Ichthyol., Occas. Pap. 6:57-61.

SPARTA, A.

1937. Contributo alla conoscenza dello sviluppo embrionale e postembrionale nei Murenoidi. 1-Coecula imberbis (De la Roche). 2-Ophichthys remicaudas (Kaup). Mem. R. Com. Talassogr. Ital. $244,16 \mathrm{p}$.

1938a. Contributo alla conoscenza dello sviluppo embrionale e postembrionale nei Murenoidi. 3-Coecula coeca (L.). Mem. R. Com. Talassogr. Ital. 248, $10 \mathrm{p}$.

1938b. Contributo alla conoscenza dello sviluppo embrionale e postembrionale nei Murenoidi. 4-Ophisoma balearicum De la Roche. Mem. R. Com. Talassogr. Ital. 252, 9 p.

1939a. Contributo alla conoscenza della sviluppo embrionale e postembrionale nei Muraenoidi.6. Ophisurus serpens L. Mem. R. Com. Talassogr. Ital. 267:1-12.

1939b. Contributo alla conoscenza della sviluppo embrionale e postembrionale nei Muraenoidi. 7-Chlopsis bicolor (Raf.). Mem. R. Com. Talassogr. Ital. 268:1-7.

1940. Contributo alla conoscenza dello sviluppo embrionale e postembrionale nei Murenoidi. 8. Echelus myrus L. Mem. R. Com. Talassogr. Ital. 273, 6 p.

1942. Uova, stadi embrionale, prelarve e larve di Nettastoma melanurum Raf. Arch. Oceanogr. Limnol. 2:151-158.

WADE, R. A.

1962. The biology of the tarpon, Megalops atlanticus, and the oxeye, Megalops cyprinoides, with emphasis on larval development. Bull. Mar. Sci. 12:545-622.

WEBER, M.

1913. Die fische der Siboga-Expedition. Siboga Exped. 65, 710 p.

\section{APPENDIX}

Numbers of myomeres and vertebrae for species listed in this paper.

\section{Albulidae}

Albula vulpes ................ 68-74

A. nemoptera . . . . . . . . . . . . 77-80

Elopidae

Megalops atlantica ............. 53-57

M. cyprinoides . . . . . . . . . . . 65-67

Elops saurus . . . . . . . . . . . . . . . 73-80

Syaphobranchidae: Dysomminae

Dysomma anguillare . . . . . . . . . . . . . . 119-130

D. brevirostre . . . . . . . . . . . . . . . 195-204

Dysommina rugosa . . . . . . . . . . . . . . . 126-134

Atractodenchelys phrix . . . . . . . . . . . . 169-173

Haptenchelys texis . . . . . . . . . . . . . 126-128

Synaphobranchidae: Synaphobranchinae

Synaphobranchus affinis . . . . . . . . 128-139

S. brevidorsalis . . . . . . . . . . . . 130-135

S. oregoni ....................142-148

S. kaupi .................... 146-150

Histiobranchus infernalis . . . . . . . . . . 126-140

Ilyophis brunneus . . . . . . . . . . . . . 144-151
Synaphobranchidae: Simenchelyidae

Simenchelys parasiticus . . . . . . . . . . 121-125

Saccopharyngoidei: Eurypharyngidae

Eurypharynx pelecanoides ........... 97-125

Saccopharyngoidei: Saccopharyngidae

Saccopharynx spp. . . . . . . . . . . . 138-250

Moringuidae

Moringua edwardsi . . . . . . . . . . . . . . . 113-122

Neoconger spp. .................. 96-110

Nettastomatidae

Nettastoma melanurum . . . . . . . . . . . 190-207

Cyemidae

Cyema atrum ..................... 80

Ophichthidae

Myrophis punctatus . . . . . . . . . . 138-148

Ahlia egmontis . . . . . . . . . . . . 157-167

Pisodonophis cruentifer . . . . . . . . . 146-152

Anguillidae

Anguilla anguilla . . . . . . . . . . . . . . 111-119

A. rostrata . . . . . . . . . . . . . . . . . . 104-111 
Derichthyidae

Nessorhamphus danae .............. 135-145

$N$. ingolfianus . . . . . . . . . . . . 149-159

Derichthys serpentinus . . . . . . . . . . 126-134

Serrivomeridae

Platuronides acutus ................ 153-158

P. danae ....................... 165-170

Serrivomer beani .................. . 154-165

S. brevidentatus ................ 155-165

S. parabeani .................. 156-163

Muraenidae

Anarchias yoshiae ................ 107-114

Uropterygius juliae ................ 118-123

Channomuraena vittata ................ ca. 149

Gymnothorax nigromarginatus . . . . . . . 137-145

G. saxicola ...................... 135-144

G. ocellatus ................. 142-150

G. sp. ..................... 132-137

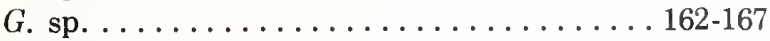

G. sp..................... 163-174

G. moringa .................... 134-142

G. funebris ................. 139-145

G. polygonius ............... 134-140

G. vicinus ..................... 129-136

Enchelycore nigricans . ............ 141-147

E. carychroa ................... 131-140

Muraena miliaris .............. 118-126

M. pavonina ................... 126-128

M. punctata ................. 128-132

M. retifera ................... 128-135

M. robusta ................. 153-156

Rabula acuta .................. 123-129

Echidna catenata ............... 114-119

Nemichthyidae

Avocettina infans ................. 181-201

A. acuticeps ..................... 198-216

A. paucipora ................ 175-188

A. bowersi ...................... 177-192

Labichthys carinatus . . . . . . . . . . . 174-191

L. yanoi ... . . . . . . . . . . . . . . . . . 178-190

Nemichthys spp............ more than 300

Xenocongridae

Kaupichthys hyoproroides (except Hawaii) . 109-123

K. hyoproroides (Hawaii) . . . . . . . . . 97-98

K. atronasus ....................... 114

K. brachychirus .................. 108-116

K. nuchalis .....................121-125

Catesbya pseudomuraena ............. 136-141

Chilorhinus suensoni................ 98-105

C. platyrhynchus ................. 107-112

Chlopsis bicolor................... 127-134

C. olokun ..................... . 125-139

C. bicollaris ....................... 138-145

C. apterus ....................... 136
C. dentatus ................... 116-124

Robinsia catherinae .............. 130-136

Heterenchelyidae

Pythonichthys microphthalmus ........ . 110-121

P. macrurus ................... . . . 124-136

P. sanguineus ................. 108

P. asodes ..................... 126-135

Panturichthys isognathus ............. 149-162

P. longus ..................... 209:227

P. fowleri ...................... ca. 150

Congridae: Bathymyrinae

Ariosoma balearicum . . . . . . . . . . . 120-137

A. selenops .................. 158-174

A. analis ..................... 146-150

A. coquettei ................... 155-160

Paraconger guianensis . . . . . . . . . . . . 126-131

P. caudilimbatus ..................121-125

Parabathymyrus oregoni ............ 149-152

Congridae: Congrinae

Conger oceanicus . . . . . . . . . . . . . . 140-147

C. esculentus ................... 132-133

C. triporiceps .................... 156-161

Gnathophis bracheatopos ............. 125-130

G. bathytopos ................... 128-133

G. tritos ..................... 136-138

Uroconger syringinus . . . . . . . . 200-220

U. lepturus . . . . . . . . . . . . . . . 200-220

Rhechias thysanochila ............. 147-149

$R$. vicinalis .................... 170-176

R. bullisi .................... 174-181

Pseudoxenomystax dubius and related forms 123-144

Acromycter perturbator . . . . . . . . . . 157-168

Hildebrandia flava ............... . 153-171

H. gracilior . . . . . . . . . . . . 176-182

H. guppyi .................. 173.178

Rhynchoconger ectenurus ............ 155-159

Pseudophichthys splendens ........... 132-135

Congridae: Heterocongrinae

Nystactichthys halis .................... 165

Muraenesocidae

Paraxenomystax spp. .............. 170-215

Muraenesox cinereus . ............... 145-159

M. bagio .................... 128-141

Congresox talabonoides ............. 132-145

C. talabon ....................... 143-149

Cynoponticus savanna .............. 131-136

Gavialiceps taeniola . . . . . . . . . . . . 230-261

Other congrid-like eels

Coloconger meadi .................. 150-163

Macrocephenchelyidae

Macrocephenchelys brachialis ........... 182

Myrocongridae

Myroconger compressus ............... 131 


\section{ERRATA}

NOAA Technical Report NMFS Circular 147: Guide to the Identification of General of the Fish Order Ophidiiformes With a Tentative Classification of the Order, by Daniel M. Cohen and Jorgen G. Nielsen.

Page 2, bottom of Table 1, blank spot, add: Aphyonidae 
388. Proceedings of the first U.S.-Japan meeting on aquaculture at Tokyo, Japan, October 18-19, 1971. William N. Shaw (editor). (18 papers, 14 authors.) February 1974, iii +133 p. For sale by the Superintendent of Documents, U.S. Government Printing Office, Washington, D.C. 20402.

389. Marine flora and fauna of the northeastern United States. Crustacea: Decapoda. By Austin B. Williams. April 1974, iii + 50 p., 111 figs. For sale by the Superintendent of Documents, II.S. Government Printing Office, Washington, D.C. 20402.

390. Fishery publications, calendar year 1973: Lists and indexes. By Mary Ellen Engett and Lee C. Thorson. September 1974, iv + 14 p., 1 fig. For sale by the Superintendent of Documents, U.S. Government Printing Office, Washington, D.C. 20402.

391. Calanoid copepods of the genera Spinocalanus and Mimocalanus from the central Arctic Ocean, with a review of the Spinocalanidae. By David M. Damkaer. June $1975, x+88$ p., 225 figs., 4 tables. For sale by the Superintendent of Documents, U.S. Government Printing Office, Washington, D.C. 20402.

392. Fishery publications, calendar year 1974: Lists and indexes. By Lee C. Thorson and Mary Ellen Engett. June 1975 , iv +27 p., 1 fig.

393. Cooperative Gulf of Mexico estuarine inventory and study-Texas: Area description. By Richard A. Diener. September 1975, vi + 129 p., 55 figs., 26 tahles.

394. Marine Flora and Fauna of the Northeastern United States. Tardigrada. Bi Leland W. Pollock. May 1976, iii +25 p., figs. For sale hi the Superintendent of Documents, U.S. Government Printing Office, IVanhington. D.C. 20402 .

395. Report of a colloquium on larval fish mortality studies and their relation to fishery research, January 1975. By John R. Hunter. May 1976, iii +5 p. For sale by the Superintendent of Documents, U.S. Government Printing Office, Washington, D.C. 20402. 
UNITED STATES

DEPARTMENT OF COMMERCE

PENN STATE UNIVER

DAT OCEANIC AND ATMOSPHERIC ADMINISTRATION

NATIONAI MARINE FISHERIES SERVICE

SCIENTIFIC PUBLICATIONS STAFF

ROOM 450

1107 NE ASTHST

SEATILE WA 9810

OFFICIAL BUSINESS

\section{NOAA SCIENTIFIC AND TECHNICAL PUBLICATIONS}

NOAA, the National Oceanic and Atmospheric Administration, was established as part of the Department of Commerce on October 3,1970 . The mission responsibilities of NOAA are to monitor and predict the state of the solid Earth, the oceans and their living resources, the atmosphere, and the space environment of the Earth, and to assess the socioeconomic impact of natural and technological changes in the environment.

The six Major Line Components of NOAA regularly produce various types of scientific and technical information in the following kinds of publications:

PROFESSIONAL PAPERS-Important definitive research results, major techniques, and special investigations.

TECHNICAL REPORTS-Journal quality with extensive details, mathematical developments, or data listings.

TECHNICAL MEMORANDUMS-Reports of preliminary, partial, or negative research or technology results, interim instructions, and the like.

CONTRACT AND GRANT REPORTS-Reports prepared by contractors or grantees under NOAA sponsorship.
TECHNICAL SERVICE PUBLICATIONSThese are publications containing data, observations, instructions, etc. A partial listing: Data serials; Prediction and outlook periodicals; Technical manuals, training papers, planning reports, and information serials; and Miscellaneous technical publications.

ATLAS-Analysed data generally presented in the form of maps showing distribution of rainfall, chemical and physical conditions of oceans and atmosphere, distribution of fishes and marine mammals, ionospheric conditions, etc.

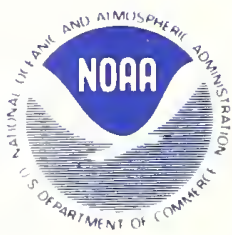

Informetion on avallablilty of NOAA publications can be obtalned from:

ENVIRONMENTAL SCIENCE INFORMATION CENTER

ENVIRONMENTAL DATA AND INFORMATION SERVICE NATIONAL OCEANIC AND ATMOSPHERIC ADMINISTRATION

U.S. DEPARTMENT OF COMMERCE

6009 Executlve Boulevard

Rockville, MD 20852 